UNIVERSIDADE DE SÃO PAULO

ESCOLA DE COMUNICAÇÕES E ARTES

PATRICIA CARLA GONÇALVES SALVATORI

O papel das Relações Públicas para construção de cultura e reconstrução de relacionamentos em processos de fusões 


\section{O papel das Relações Públicas para construção de cultura e reconstrução de relacionamentos em processos de fusões}

Dissertação apresentada ao Programa de PósGraduação em Ciências da Comunicação (PPGCOM) da Escola de Comunicação e Artes da Universidade de São Paulo para a obtenção do título de Mestre em Ciências da Comunicação

Área de concentração: Interfaces Sociais da Comunicação

Linha de Pesquisa: Políticas e Estratégias de Comunicação

Orientador: Prof. Dr. Luiz Alberto de Farias

São Paulo 
Autorizo a reprodução e divulgação total ou parcial deste trabalho, por qualquer meio convencional ou eletrônico, para fins de estudo e pesquisa, desde que citada a fonte.

\section{Catalogação na Publicação \\ Serviço de Biblioteca e Documentação \\ Escola de Comunicações e Artes da Universidade de São Paulo Dados fornecidos pelo(a) autor(a)}

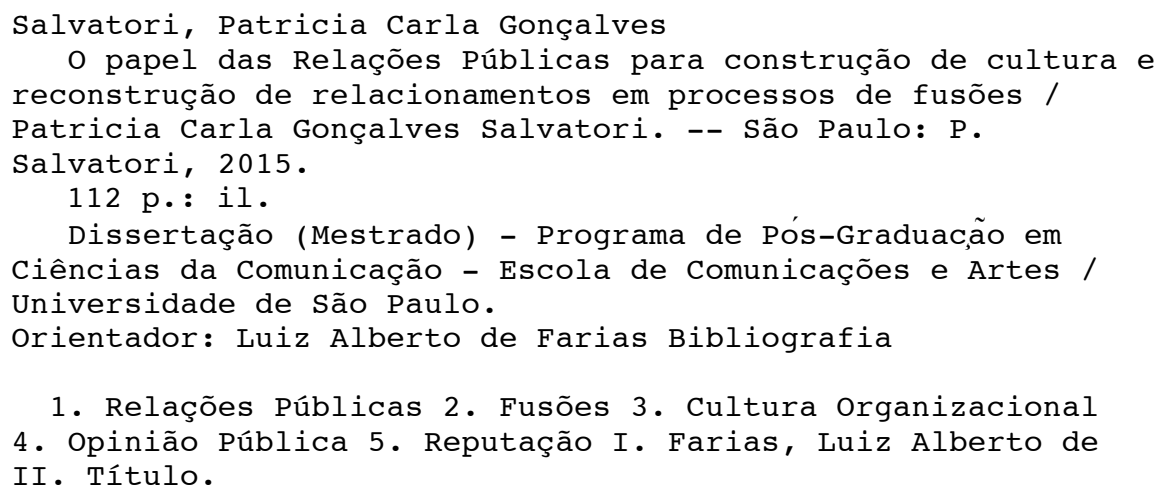

1. Relações Públicas 2. Fusões 3. Cultura Organizacional 4. Opinião Pública 5. Reputação I. Farias, Luiz Alberto de II. Título.

CDD 21.ed. - 659.2 
SALVATORI, Patrícia Carla Gonçalves. O papel das Relações Públicas para construção de cultura e reconstrução de relacionamentos em processos de fusões. Dissertação apresentada ao Programa de Pós-Graduação em Ciências da Comunicação (PPGCOM) da Escola de Comunicações e Artes da Universidade de São Paulo para obtenção do título de Mestre em Ciências da Comunicação.

Aprovada em:

Banca Examinadora:

Prof. Dr.

Julgamento:

Prof. Dr.

Julgamento:

Prof. Dr. Luiz Alberto de Farias (orientador) Julgamento:
Instituição:

Assinatura:

Instituição:

Assinatura:

Instituição: ECA/USP

Assinatura: 
Dedico este trabalho à minha filha Larissa, que há uma década me ensina a olhar o mundo de um jeito diferente e aprender diariamente a buscar novos caminhos. 


\section{AGRADECIMENTOS}

Ao meu marido Aldo, que me incentivou a acreditar e buscar a felicidade, o que realmente importa para transformarmos o futuro. Minha coragem e dedicação não existiriam sem o seu apoio incondicional.

Aos meus pais, em sua sabedoria autodidata, por nunca medirem esforços para que o estudo fosse a prioridade máxima dos cinco filhos.

Ao meu mestre orientador Prof. Dr. Luiz Alberto de Farias, pela generosidade e carinho nos conselhos e reflexões sobre o estudo, trabalho e futuro; pela confiança que demonstrou em todos os momentos; e pelo modelo profissional e pessoal que me inspira.

Aos professores do mestrado Prof. Dra. Margarida Kunsch, Prof. Dr. Paulo Nassar e Prof. Dra. Rosa Maria Fischer, que contribuíram fortemente para meu desenvolvimento acadêmico, em conjunto com meu orientador.

Aos executivos que participaram das entrevistas e permitiram a realização da pesquisa: Adriana Vera e Silva, Gerente de Relações Institucionais e Governamentais da Latam; Marcos Caetano, Diretor Global de Comunicação Corporativa da BRF; Paulo Marinho, Superintendente de Comunicação Corporativa do Itaú Unibanco; e Valerie Cardier Adem, Superintendente de Endomarketing do Itaú Unibanco. 


\section{RESUMO}

Esta dissertação busca o entendimento da correlação entre o trabalho estratégico de relações públicas nos processos de fusões de grandes organizações e o sucesso destes processos. Por meio de estudo de casos múltiplos a partir de evidências de duas fontes, entrevistas e análise de documentação, estuda o impacto da comunicação como estratégia na reconstrução do relacionamento de três organizações - BRF, Itaú Unibanco e LATAM - com seus públicos de interesse e identifica a correlação entre os processos comunicacionais analisados e a construção de novas identidades e culturas organizacionais. A pesquisa avaliou os históricos das organizações oriundas, seus princípios organizacionais, as razões para as fusões, os planos de comunicação institucional e interna específicos, os relacionamentos com stakeholders pré e pós-fusões, integração das áreas de comunicação/relações públicas e atual organograma das áreas. Como resultados, foi detectada forte presença dos fundadores e seus descendentes nos modelos e valores estabelecidos, que tendem a ser reforçados ou anulados conforme seus novos interesses. Apesar disso, suas histórias e estilos de lideranças mais diferem entre si do que se parecem. A análise dos princípios organizacionais aponta desarmonia entre o discurso de equilíbrio de iguais com a prática de predomínio de um dos lados, esquecimento do passado ou perpetuação das companhias fusionadas. A comunicação instrumental se faz presente, principalmente nos inícios dos processos combinatórios e tende a se tornar estratégica conforme concentra esforços para o entendimento e aceitação da alta liderança sobre novos padrões e diretrizes e como fomentadora de uma relação transparente, diversa e equilibrada destas lideranças com suas equipes e da organização com todas as pessoas envolvidas com a organização. Neste patamar, as relações públicas atuam como agente de transformação e são fundamentais para a criação da nova cultura, alinhada às estratégias do negócio, e para a reconstituição dos relacionamentos com os públicos de interesse, por meio de uma comunicação dialógica e estratégica.

Palavras-chave: Relações Públicas; Fusões; Cultura Organizacional; Opinião Pública; Reputação. 


\begin{abstract}
This paper seeks to understand the correlation between strategic public relations in mergers of large organizations and the success of these processes. Through multiple case study evidence from two sources: interviews and documentation analysis, studies the impact of communication as a strategy in the relationship reconstruction of three organizations - BRF, Itaú Unibanco and LATAM - with theirs stakeholders and identifies the correlation between communication processes analyzed and the construction of new identities and organizational cultures. The research evaluated the historical derived organizations, their organizational principles, the reasons for the mergers, the corporate and internal communication plans, relationships with stakeholders pre and post-mergers, integration of the areas of communication / public relations and current organization chart of these areas. As a result, it was detected a strong presence of the founders and their descendants in the models and established values, which tend to be reinforced or canceled as their new interests. Nevertheless, their stories and leadership styles differ more than look like. Analysis of organizational principles points disharmony between the equal balance speech to the practice of predominance of one side, past forgotten or perpetuation of the merged companies. Instrumental communication is present, especially in the early combinatorial processes and tends to become strategic when concentrate efforts so that the senior leadership understand and accept the new standards and guidelines and as a sponsor of a transparent diverse and balanced relationship of these leaders with their teams and between the organization and all the people involved with the organization. At this level, public relations act as an agent of transformation and are fundamental to the creation of new culture, aligned to business strategies, and the reconstruction of relationships with stakeholders, through a dialogical and strategic communication.
\end{abstract}

Key words: Public Relations; Mergers; Organizational Culture; Public Opinion; Reputation. 


\section{LISTA DE QUADROS}

Quadro 1 - Diferentes tipos de combinação estratégica 16

Quadro 2 - Impacto dos públicos sobre a percepção da organização 42

Quadro 3 - Teoria de excelência em Relações Públicas 46

Quadro 4 - Merger Mix $\quad 51$

Quadro 5 - Protocolo de seleção da amostra 60

Quadro 6 - Composição da amostra do estudo de casos múltiplos 61

Quadro 7 - Linhas do tempo das fusões estudadas 63

Quadro 8 - Análise comparativa dos perfis das organizações 63

Quadro 9 - Restrições impostas pelo CADE para aprovação da fusão entre Sadia e Perdigão 66

Quadro 10 - Comparativo de indicadores da BRF de 2009 e 2014

Quadro 11 - Comparativo de indicadores do Itaú Unibanco de 2008 e 2014

Quadro 12 - Comparativo de indicadores da LATAM de 2010, 2012 e $2014 \quad 72$

Quadro 13 - Princípios organizacionais da BRF 76

Quadro 14 - Princípios organizacionais do Itaú Unibanco 76

Quadro 15 - Princípios organizacionais da LATAM $\quad 77$

Quadro 16 - Aderência das organizações às questões de combate à Merger

Syndrome 88

Quadro 17 - Aderência das organizações às categorias e princípios da

Teoria da Excelência em Relações Públicas 89

Quadro 18 - Comparativo de premiações de destaque reputacional pré

e pós-fusões $\quad 90$

Quadro 19 - Relações públicas como agente de transformação cultural e relacional nos processos de fusões 


\section{SUMÁRIO}

Introdução 11

1. Fusões e aquisições: conceitos e cenário brasileiro 16

1.1. Diferenças conceituais e história das fusões e aquisições 16

1.2. Aspectos legais e regulatórios das fusões e aquisições no Brasil 23

1.3. Realidade e cenários no mercado brasileiro 24

2. Organizações e sociedade 27

2.1.Padrões culturais e políticos das organizações e interculturalidade $\quad 27$

2.2. Opinião pública: natureza, conceitos 35

2.3. Influência da opinião pública nas organizações 40

3. Relações Públicas na gestão reputacional das organizações 44

3.1. Relações públicas: definição e atribuições 44

3.2. Reputação: conceitos, interfaces e mensuração 52

4. Relações Públicas em processos de fusões: estudo de casos múltiplos 57

4.1. Objeto da pesquisa $\quad 57$

4.2. Metodologia de análise 58

4.3. Estrutura da pesquisa, protocolo e proposta de dados 59

4.4. Resultados da pesquisa 63

Conclusão: reflexões e tendências $\quad 92$

$\begin{array}{ll}\text { Referências } & 97\end{array}$

$\begin{array}{ll}\text { Anexos } & 104\end{array}$ 


\section{INTRODUÇÃO}

No decorrer das últimas décadas, as organizações vêm passando por marcantes transformações estruturais em busca de crescimento acelerado, ganhos de escala, redução de custos operacionais e adaptação às mudanças econômicas e tecnológicas contemporâneas. Dentre as práticas mais frequentes neste sentido encontram-se os processos de fusões e aquisições. Em que pesem as vantagens competitivas decorrentes da unificação de duas corporações que se extinguem para a formação de uma nova entidade jurídica, os impactos negativos destes processos podem causar danos reputacionais e financeiros relevantes à nova instituição.

A integração cultural costuma ser o maior desafio de negócios durante o desenvolvimento de uma fusão e segundo pesquisas internacionais (BARROS, 2003; ANDERSON, HAVILA; NILSSON, 2012), está entre as últimas questões a considerar no processo decisório para uma nova fusão ou aquisição, o que contribui fortemente para uma taxa de fracasso superior a $50 \%$. O processo de integração costuma focar as sinergias operacionais, o que prioriza a unificação de estratégias de negócios e suas estruturas, relegando a dimensão da cultura a segundo plano. A cultura organizacional é um dos elementos que gera o orgulho de pertencer à instituição, seja como colaborador, cliente ou parceiro, e ao ser descartada, possibilita o surgimento dos choques culturais e da relação "nós contra eles", que pode derivar para prejuízos para a organização, por meio de oposição ou boicote, e também para as pessoas envolvidas, interna e externamente. (MARKS; MIRVIS, 2010)

A perda, mesmo que temporária, das referências, da memória empresarial e consequentemente do espírito de grupo derivam para a deterioração do clima organizacional e comprometem a percepção dos stakeholders, termo cunhado por Robert Freeman (1984) para designar todas as pessoas que impactam ou são impactadas pela empresa, sobre a reputação da instituição. Neste contexto, o gerenciamento do fator humano, por meio de um cuidadoso planejamento de comunicação pode proporcionar a linha tênue entre o sucesso e insucesso do processo de integração e construção de uma nova reputação corporativa. A comunicação pode exercer um papel de maior amplitude, oferecendo sentido às 
mudanças, sob a ótica dialógico-recursiva de sentidos de Baldissera (2009, p. 136), que atingem os stakeholders da nova empresa. De acordo com Baldissera (2009),

[...] na medida em que a comunicação se qualifica como dialógica, apresenta-se como lugar e meio para que os sujeitos possam se realizar como diversidade, atualizando suas ideias, seus pensamentos, suas concepções e/ou suas diferenças sem que uns se sobreponham aos outros. (BALDISSERA, 2009, p. 143)

É preciso transpor a realidade antiga do 'não mais', ou seja, aquilo que não existe mais, para uma nova realidade em construção do 'ainda não'. Isso pode se dar por meio da comunicação mecanicista de transmissão de informações, mas também pela construção de uma nova identidade e preservação de valores e da autoestima dos públicos envolvidos. Duarte e Monteiro (2009, p. 341) afirmam que o processo de gestão da comunicação deve criar uma consciência comunicativa, por meio da transparência, confiança e estimulo à cooperação, que permita a fluidez da comunicação no ambiente corporativo. Para isso, o ato comunicativo deve ser composto tanto pelo conteúdo da mensagem como pela relação estabelecida entre os participantes do processo.

Lembrando o conceito de relações públicas de Kunsch (2003, p. 89), como a promoção e administração de relacionamentos entre organizações e seus públicos, valendo-se de estratégias e programas de comunicação de acordo com as diferentes realidades do ambiente social e considerando suas obrigações e seu compromisso de prestação de contas à sociedade. Com isso, a organização deixa de ser o centro do processo comunicacional, tornando-se apenas mais um dos interlocutores no espaço comum, juntamente com os demais atores sociais (OLIVEIRA; PAULA, 2007). Portanto, o ponto de partida deste estudo é a crença de que organizações resultantes de processos de fusões necessitam, mais do que qualquer outra estrutura organizacional, do trabalho estratégico de relações públicas, pautado por processos comunicacionais estruturados em diálogo e transparência, conforme preconiza James Grunig, em sua Teoria da Excelência em Relações Públicas. (GRUNIG, FERRARI; FRANÇA, 2011, p. 43) A partir de então, se torna possível a construção da nova cultura organizacional que norteará a organização e a reconstrução de relacionamentos perenes e saudáveis com seus stakeholders e consequentemente a valoração de seu ativo reputacional. 
As motivações para a escolha do tema deste estudo recaem sobre meu percurso profissional. Ao longo de vinte anos, trabalhei em organizações privadas de médio e grande porte e me deparei com os desafios contemporâneos das organizações de sucesso: suas constantes transformações. Vivenciei, no desempenho de funções de relações públicas, dois impactantes processos de aquisições e um gigantesco processo de fusão. Ao passo que a experiência prática me impactou profundamente, gerou o interesse cientifico pelo assunto. Contudo, ainda que as combinações empresariais tenham se tornado conduta recorrente nas organizações e sejam objetos de estudos e teorias de diversos especialistas do campo da administração, são raros os estudos acadêmicos, pelo olhar da comunicação organizacional, que apontem o papel efetivo das relações públicas nesses processos.

Portanto, o objetivo central desta pesquisa é oferecer uma contribuição para o campo do conhecimento e entendimento da correlação entre o trabalho estratégico de relações públicas nos processos de fusões de grandes organizações e o sucesso destes processos. A partir dos pressupostos centrais de que o processo comunicacional estratégico facilita o entendimento e a aceitação das mudanças da organização para os públicos, contribui fortemente para a reconstrução destes relacionamentos, favorece o estabelecimento de novas culturas organizacionais e por consequência, o trabalho estruturado de relações públicas impacta diretamente o sucesso dos processos de fusões das organizações, foram trabalhados cinco núcleos de análise na revisão bibliográfica: combinações empresariais com destaque para as modalidades das fusões e aquisições; cultura organizacional; opinião pública; relações públicas; e reputação, sendo quatro imbricados no campo de estudo da comunicação organizacional, à exceção dos conceitos relacionados às fusões.

O segundo capítulo traz a revisão conceitual sobre os diferentes tipos de combinações estratégicas (MARKS; MIRVIS, 2010), com destaque para as operações denominadas fusões e aquisições, divididas por uma linha tênue de entendimento e percepções (BARROS, 2003; TANURE; CANÇADO, 2005), bem como os motivos para esta ocorrência (GALPIN; HERNDON, 2007), e seus impactos para as organizações envolvidas. Neste sentido, um importante aspecto estudado foi o grau de importância dos fatores humanos nestes processos versus a importância 
que as organizações dão às pessoas, considerando os efeitos positivos e negativos das variáveis destes posicionamentos (APPELBAUM et al., 2000; CARTWRIGHT; COOPER, 1996; MARKS; MIRVIS, 2010). O cenário de fusões e aquisições no mercado brasileiro se apresenta com base no entendimento dos aspectos legais e regulatórios do país e da realidade e histórico mapeados, com o embasamento dos autores Barros (2003), Rossetti (2001) e Tanure e Cançado (2005).

O terceiro capítulo se propõe a compreender as organizações como sistemas sociais, que enfrentam o desafio de constantes modificações, e constroem e são construídas por seus padrões culturais e políticos. Para tanto, foram resgatados os conceitos de cultura para o ambiente organizacional (FLEURY; FISCHER, 2012; PETTIGREW, 2012; SCHEIN, 1984), gestão de elementos simbólicos, mudanças de padrões culturais (FREITAS, 2007; SCHULER, 2009), memória organizacional (CANDAU, 2011; NASSAR, 2009), relação entre comunicação e cultura (MARCHIORI, 2009) e interculturalidade, a partir dos conceitos de Hofstede (1997). Em continuidade, traz a reflexão sobre o conceito e natureza de opinião pública (ANDRADE, 2003; BOURDIEU, 1973; CHILDS, 1967; LIPPMANN, 2008; ROUSSEAU, 2011), com base no entendimento do conceito de públicos (ANDRADE, 2001; FRANÇA, 2012; SIMÕES, 1995; TARDE, 1990; TOFFLER, 1995), além de sua influência para as organizações (FARIAS, 2009b; LIPPMANN, 2008; MARQUES; MAFRA, 2013)

Relações Públicas na gestão reputacional das organizações compõe o foco de análise do quarto capítulo. O referencial teórico sobre relações públicas e comunicação organizacional, bem como suas diferenciações, se desdobram a partir das visões de Andrade (2001, 2003); Fortes (2003); França (2006); Grunig, Ferrari e França (2011); Kunsch (2003, 2006, 2009); Nassar (2007, 2009); e Simões (1995). A comunicação é analisada em suas várias perspectivas (PUTNAM, 1987), com destaque para a comunicação estratégica (OLIVEIRA; PAULA, 2007). Outro importante tópico estudado é o planejamento estratégico da comunicação (FARIAS, 2011; KUNSCH, 2003). O papel das relações públicas nos processos de fusões surge das proposições de uma abordagem multi-stakeholder de Anderson, Havila e Nilsson (2012), das percepções de comunicação com público interno de Casali (2006) e Felix Mateus (2012) e da teoria de Merger Mix, de Balmer e Dinnie (1999). 
Para abordar os conceitos, interfaces e mensuração de reputação, foram usados os autores Almeida (2005, 2009); Barnett, Jermier e Lafferty (2006); Fombrun (2007); Fombrun e Riel (2004); e Rosa (2007), a partir do entendimento das concepções de identidade organizacional e imagem. (BARNETT; JERMIER; LAFFERTY, 2006; BALDISSERA, 2007; IASBECK, 2007)

O quinto capítulo apresenta os resultados da pesquisa sobre as relações públicas em processos de fusões, efetuada com três organizações resultantes de processos de fusões no cenário brasileiro entre os anos de 2008 e 2012: BRF, Itaú Unibanco e LATAM. Trata-se de uma pesquisa qualitativa com estudo de casos múltiplos, a partir de evidências de duas fontes: entrevistas com os executivos da área de comunicação institucional e interna das organizações pré-estabelecidas, e análise de documentação. O estudo teve início com um protocolo de seleção, que surgiu da compilação do Relatório de Fusões e Aquisições no Brasil da consultoria PWC e do Boletim de Fusões e Aquisições da Associação Brasileira das Entidades dos Mercados Financeiro e de Capitais (ANBIMA), no período de 2008 a 2012. Com base em critérios pré-estabelecidos de cruzamento dos 380 casos mapeados com os principais ranking nacionais e internacionais de destaque reputacional, além da escolha intencional somente por fusões, o levantamento inicial derivou para uma amostra de sete empresas, que resultou nas três organizações estudadas.

Os dados são apresentados a partir de um panorama geral de cada um dos três processos, seguidos pelas análises de seus históricos, estilos de lideranças, princípios organizacionais e a seguir, os detalhamentos dos processos comunicacionais e de relacionamentos com seus stakeholders internos e externos. $\mathrm{Na}$ sequência, propusemos dois estudos comparativos: nível de aderência das organizações às questões apontadas por Marks e Mirvis (2010) como fundamentais para o combate da Merger Syndrome apresentada no decorrer do segundo capítulo, seguido pelo nível de aderência às categorias e princípios da Teoria da Excelência em Relações Públicas, de James Grunig (2011), apresentados no quarto capítulo. 


\section{FUSÕES E AQUISIÇÕES: CONCEITOS E CENÁRIO BRASILEIRO}

A abordagem da temática das relações públicas nos processos de fusões requer em primeira instância uma análise depurada do conceito de fusão, sua inter-relação com os diversos modelos de combinações estratégicas entre organizações, as razões para que o mercado estabeleça estes novos modelos e as consequências positivas e negativas decorrentes das movimentações, principalmente o que se refere às pessoas envolvidas.

\subsection{Diferenças conceituais e história das fusões e aquisições}

Para dar início ao estudo de combinações empresariais, terminologia adotada por Rhinow (2006) para designar fusões e aquisições, se faz necessário o olhar conceitual para os diferentes formatos de transações que existem no cenário empresarial. De acordo com os pesquisadores Marks e Mirvis (2010, p. 12), que consolidaram seus estudos na década de 1990 com a publicação "Joining Forces", revisitada em 2010, existe um leque de possibilidades de transações entre empresas que buscam operações conjuntas, que evoluem proporcionalmente ao aumento do nível de investimento, controle, impacto e dificuldade, conforme apresentado no quadro 1.

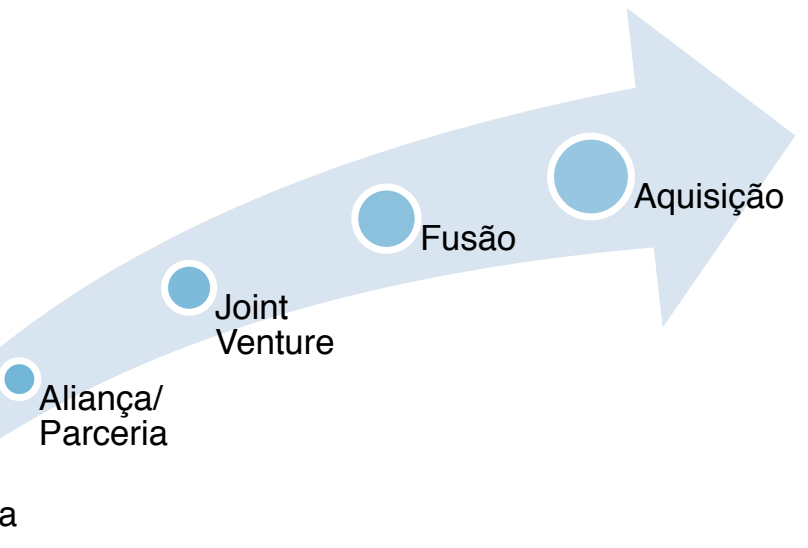

Níveis de investimento, controle, impacto, integração, dificuldade e reversibilidade

Quadro 1 - Diferentes tipos de combinação estratégica. Fonte: elaborado pela autora, com base em conceito de Barros, 2003, p. 19 
As combinações fluem gradativamente de uma relação superficial como o licenciamento ao extremo processo integrativo entre duas corporações: as fusões e aquisições. A partir do entendimento que os processos de licenciamento, parcerias e joint ventures abordam vínculos menos profundos e, portanto, demandantes de estratégias comunicacionais diferentes das que serão analisadas nesta obra, o enfoque do estudo será dado somente para as operações classificadas como fusões e aquisições.

Aquisição é definida como um processo no qual a adquirente assume o controle acionário da adquirida, ou seja, uma empresa compra outra, que deixa legalmente de existir e todo seu capital é incorporado pela compradora. Já a fusão representa a combinação de duas empresas que deixam de existir para a formação de uma terceira, com nova identidade (BARROS, 2003, p. 19). Em que pese o aspecto de equilíbrio entre as partes nas fusões, o que tradicionalmente ocorre é que um dos lados tende a predominar sobre o outro, seja por ter havido um maior aporte de recursos financeiros, humanos ou materiais na associação, seja pelo valor de seus ativos intangíveis, ou mesmo por um histórico mais acentuado de transações desse porte. No entendimento de Tanure e Cançado (2005, p. 12), as fusões praticamente inexistem.

\footnotetext{
Apesar da suposta igualdade entre os parceiros, o que geralmente ocorre é o controle por parte de um deles. E, de fato, o número de fusões 'reais' é tão baixo que, para propósitos práticos, a expressão 'fusões e aquisições' basicamente significa aquisições. (TANURE; CANÇADO, 2005, p, 12)
}

Já para Marks e Mirvis (2010, p. 13), a questão maior encontra-se na percepção das pessoas e não no fato em si. "O que pode ser anunciada como fusão raramente é percebida como uma combinação de iguais pelos membros de pelo menos uma das organizações parceiras". Pessoas de um lado sentem-se propensas a um sentimento de superioridade e mais direitos no processo, enquanto que aqueles que estão do outro lado ficam em uma posição relativamente fraca e de maior ameaça para si, seu emprego e o modo de executar seu trabalho. Pode-se deduzir, portanto, que a linha entre fusões e aquisições é bastante tênue e mesmo quando a combinação é assumidamente uma fusão, é possível que haja ruído entre as partes, o que dificulta o processo comunicacional como um todo. 
A início da prática das combinações empresariais remonta ao final do século XIX, em processos definidos como ondas de fusões e aquisições, que oscilavam à mercê de variações na bolsa de valores norte-americana (BREALEY; MYERS, 1998). Ao passo que a economia prosperava, magnatas como Cornelius Vanderbilt e John Rockfeller faziam os primeiros movimentos de aquisições e alianças para a construção e fortalecimento de seus impérios industriais. No decorrer do século $X X$, o ritmo das combinações empresariais aumentou à medida que o mundo passava por transformações e evoluções dos pontos de vista econômico e tecnológico. Com o fortalecimento da globalização na década de 90 , houve um salto considerável nos processos de alianças corporativas, em busca de competitividade que possibilitasse crescimento e continuidade de seus negócios.

De acordo com Galpin e Herndon (2007, p. 5), as fusões e aquisições, que em décadas passadas visavam basicamente o ganho de controle de ativos subvalorizados, migraram para objetivos mais estratégicos como aquisição de base de clientes, canais de distribuição e novos mercados mundiais. Segundo os autores, hoje compram-se as competências de uma determinada organização e sua gama de talentos que alavancam e ampliam oportunidades estratégicas, visando sobressairse frente aos produtos e serviços de seus concorrentes. Com pressões cada vez maiores por resultados de curto prazo e margens de erros cada vez menores, os atuais processos de combinações buscam o enxugamento de custos, sem que isso interfira na capacidade de gerar sinergias geradoras de novas receitas.

Com isso, os processos integrativos se transformam, cada vez mais, em enormes desafios, pois buscam novos e urgentes patamares de performance enquanto, pela configuração das mudanças geradas e até que todos os esforços de integração operacional sejam finalizados, impactam negativamente os resultados de ambos os lados. Em uma analogia simplificada, é como se um avião recebesse incrementos de carga, combustível e passageiros em pleno ar, para que pudesse alcançar novos destinos, sem que isso devesse interferir negativamente em sua velocidade e altitude.

Outro aspecto importante que deve ser considerado na análise de fusões e aquisições é a contradição entre a real importância das pessoas nos processos e a 
importância que as organizações dão às pessoas envolvidas no processo. Na visão de Cartwright e Cooper (1996, p. 5), as fusões e aquisições têm sido historicamente objeto de estudo e trabalho quase exclusivo de economistas, estrategistas de mercado e consultores financeiros, portanto os aspectos financeiros e estratégicos se destacam e são amplamente debatidos na literatura de gestão empresarial. Porém, apesar de fusões e aquisições serem algo que acontece com as pessoas nas organizações, em vez das organizações em seu sentido abstrato, os autores afirmam que os aspectos humanos têm recebido relativamente pouca atenção e as pessoas, por muitas vezes, são ignoradas por serem consideradas uma questão menos importante pelos tomadores de decisões.

Em um paradoxo ainda maior, estudos apontam que os fatores humanos são cada vez mais responsáveis pelos resultados dos processos, seja pela (in)compatibilidade cultural entre as empresas ou pela forma que a integração é conduzida, não por acaso, pelas pessoas envolvidas no processo. A pouca atenção dada às pessoas torna-se um dos fatores de impacto para um eventual fracasso, que se atrela, entre outros aspectos, à incompreensão das necessidades especificas de atuação em cada etapa do processo: pré-combinação, combinação e pós-combinação. (MARKS; MIRVIS, 2010, p. 36)

- Pré-combinação: representa o período de negociação entre os representantes legais de ambos os lados. O processo decisório parte da due diligence, ou seja, análise dos balanços, retorno sobre investimento e riscos. Aspectos humanos costumam ser pouco considerados nesta etapa, não ultrapassando $20 \%$ dos casos, como relata Barros (2003, p. 26).

- Combinação: trata-se da fase do anúncio e transição. Neste ponto do processo, o fator humano se destaca como um dos maiores desafios. Além das diferenças inerentes à colisão de culturas organizacionais distintas, que serão estudadas no capítulo a seguir, as pessoas disputam por poder e posições ainda não definidas para a nova estrutura. Em meio às altas expectativas dos tomadores de decisões e aos conflitos emocionais dos funcionários, se faz necessário um eficiente e ágil plano de integração das operações, dos processos e das equipes. 
- Pós-combinação: é a fase de implementação da integração efetiva e as pessoas são encaixadas no organograma da nova organização, conhecendo e reconhecendo seu papel e suas responsabilidades. O diferencial se dá pela construção da nova cultura organizacional.

Uma das principais causas de resultados decepcionantes em fusões e aquisições, é a chamada Merger Syndrome, teoria desenvolvida por Marks e Mirvis (2010, p. 40), para o fenômeno desencadeado pela incerteza dos meses subsequentes ao anúncio, bem como pelas perspectivas de mudanças nem sempre desejadas. A síndrome surge da centralização excessiva dos gestores aliada à redução da comunicação com suas equipes, o que gera uma onda de boatos e desconfianças por parte dos funcionários, preocupados com seus futuros e carreiras. Dentre as consequências clássicas da síndrome, constam os choques culturais; surgimento da relação "nós contra eles", que acarreta necessidade de vencer o outro lado; superioridade de um dos lados frente à inferioridade de outro; ataques generalizados; e decisões baseadas em coerção. Segundo os autores, o caminho de combate à síndrome percorre cinco questões-chaves:

1) Estratégia voltada à criação de valor: as empresas podem alcançar seus objetivos estratégicos de forma mais realista, rápida ou rentável através da fusão em vez de agirem por conta própria. Para isso, uma clara e consensual definição de sinergias pode guiar um planejamento colaborativo e a tomada de decisão, evitando sentimentos como negação e tendências de autoproteção que costumam desvirtuar combinações cujas decisões são baseadas em agendas políticas;

2) Organização: as empresas têm que se organizar para a combinação. Além da parte óbvia para determinar a adequação estratégica e financeira da transação, trata-se de fazer uma análise minuciosa sobre as motivações do potencial parceiro, compatibilidade dos valores, entendimento sobre as sinergias, e confiança suficiente para que a operação seja mais do que a soma das suas partes. O alinhamento sobre novas estratégias e estruturas é essencial para o sucesso de uma combinação. Gestores de ambos os lados devem ser 
responsáveis pela gestão de transição, com base na troca de conhecimento e construção do planejamento, para alcançar sinergias esperadas;

3) Atenção às pessoas: as pessoas tem que estar preparadas psicologicamente para unir forças. Preparação psicológica educa sobre as mentalidades de vencedores e perdedores, prepara para conhecer e trabalhar com os seus pares e ajuda a lidar com as preocupações naturais e esperadas que surgem no início e aumentam, à medida que a integração seja iniciada. Construir a melhor organização possível repousa sobre uma boa identificação de lideranças e retenção de talentos de ambos os lados. Isto é conseguido por meio de critérios de seleção estrategicamente sensíveis, que ofereçam oportunidades para todos;

4) Criação de uma nova cultura desejada, com respeito às culturas pré-existentes e suas diferenças: as combinações muitas vezes perturbam formas tradicionais de se fazer as coisas e podem ameaçar as crenças e valores de um ou de ambos os lados do acordo. Cabe inicialmente aos gestores aprender sobre as culturas de seu parceiro, para começar a combater os estereótipos e equívocos, para levantar e discutir diferenças genuínas e buscar por semelhanças. Mesmo quando um dos lados domina a combinação, este deve mostrar respeito com a cultura do outro lado e explicar por que escolheu instalar seus próprios modelos. A construção de uma nova cultura implica tirar o melhor dos dois lados, portanto o ideal é que as diferenças culturais representem oportunidades de aprendizagem, em vez de rivalidade. A cultura desejada deve surgir de forma colaborativa, pela decisão conjunta de quais as características de suas culturas antigas valem a pena serem mantidas e quais são incongruentes com a nova situação;

5) Gestão da transição: estrutura de transição eficaz, baseada em planejamento e implementação das mudanças. É preciso saber para onde se quer ir, e o que é preciso para chegar lá. O ponto de partida se dá com a criação de uma equipe de transição da estrutura que viabilize o programa de integração. A participação de ambos os lados nesta equipe representa uma mensagem simbólica de que o mais importante é a união. A estrutura de transição tem o papel de direcionar a tomada de decisão, por meio de novos comportamentos e regras, que exercem 
influência considerável sobre as normas que devem prevalecer na organização emergente. Além disso, o aprendizado adquirido pode ser armazenado, com o propósito de melhor gerir combinações futuras.

Os processos de mudanças, em especial as fusões e aquisições, costumam ser muito estressantes para os indivíduos envolvidos. Na percepção de Cartwright e Cooper (1996, p. 49), os principais motivos de estresse para os envolvidos são: perda de identidade, decorrente do crescimento organizacional; falta de informações e/ou um processo de comunicação insatisfatório; medo de uma eventual demissão; interrupção ou rebaixamento na carreira; possibilidade de transferência ou realocação de função e, consequentemente, afastamento de colegas, chefes e subordinados; redução de poder, status e prestígio; e choques culturais. A partir dos pontos elencados acima, torna-se evidente que o estresse deriva de gatilhos emocionais disparados pela falta de conhecimento e clareza de futuro.

Para Appelbaum et al. (2000, p. 658), qualquer processo de mudança é intrinsecamente difícil de se submeter; no entanto, o aumento estratégico na quantidade e no modo como as informações são fornecidas aos funcionários pode aumentar significativamente as chances de sucesso. Ao passo que a empresa demonstra empatia com estas pessoas e proporciona-lhes todas as informações necessárias e válidas, pode, com isso, reduzir seu nível de estresse e aumentar sua eficácia no trabalho.

Em um olhar mais abrangente sobre o fator humano, as pessoas impactadas pelas mudanças geradas em uma combinação não se restringem ao público interno das organizações envolvidas. Cada empresa possui diversos públicos de interesse que afetam, são afetados e se interessam por ela e por suas decisões. Relações com fornecedores e clientes, por exemplo, podem ser abaladas em função das mudanças ou não. A diferença pode estar nas competências da empresa em lidar com o ponto de vista da outra parte, que não precisa reagir negativamente se o negócio não for afetado. 


\subsection{Aspectos legais e regulatórios das fusões e aquisições no Brasil}

De acordo com o artigo 228 da Lei Federal n 6.404 de 15 de dezembro de 1976, que regulamenta as companhias ou sociedades anônimas do Brasil, fusão "é a operação pela qual se unem duas ou mais sociedades para formar sociedade nova, que Ihes sucederá em todos os direitos e obrigações", enquanto que aquisição é nomeada como incorporação, "operação pela qual uma ou mais sociedades são absorvidas por outra, que lhes sucede em todos os direitos e obrigações."

Os processos de combinações empresariais do país são regulados pelo Sistema Brasileiro de Defesa da Concorrência (SBDC), estruturado a partir da promulgação da Lei Federal $n^{\circ} 12.529$, de 30 de novembro de 2011, que se tornou conhecida como Lei da Livre Concorrência. É composto por um conjunto de órgãos governamentais: o Conselho Administrativo de Defesa Econômica (CADE), autarquia federal vinculada ao Ministério da Justiça, e a Secretaria de Acompanhamento Econômico (SEAE), do Ministério da Fazenda.

Dentre as funções do Conselho Administrativo de Defesa Econômica (CADE), estão a análise e decisão sobre fusões, aquisições de controle, incorporações e outros atos de concentração econômica entre empresas que possam colocar em risco a livre concorrência. Os processos combinatórios de empresas brasileiras só são considerados válidos após sua aprovação. De acordo com o balanço de 2014 publicado no site oficial da instituição, após a aprovação da Lei n 12.529, em 2011, o tempo médio de tramitação de atos de concentração reduziu de 180 dias para 25 dias. Entretanto, por se tratar de um tempo médio, eventualmente este prazo pode se estender, sem que as empresas envolvidas tenham algum nível de interferência, principalmente em casos que envolvam órgãos reguladores setoriais e/ou de outros países. Com isso, após a divulgação da fusão ou aquisição, as empresas envolvidas entram em um período estimado, porém indeterminado, de preparo para integração de suas operações, equipes e processos, ao passo que, em tese, nenhuma ação efetiva pode ser tomada antes da aprovação legal.

Além da regulação pelo Sistema Brasileiro de Defesa da Concorrência (SBDC), determinados setores da economia brasileira possuem órgãos reguladores próprios, aos quais compete pareceres de análise e aprovação de eventuais fusões e 
aquisições. O setor da aviação civil é regulado pela Agência Nacional de Aviação Civil (ANAC), autarquia vinculada à Secretaria de Aviação Civil da Presidência da República, criada em 2005, em substituição ao Departamento de Aviação Civil (DAC) como autoridade de aviação civil e regulador do transporte aéreo no país. No setor bancário, as instituições financeiras que atuam no Brasil são reguladas e fiscalizadas pelo Banco Central do Brasil (BACEN), que dentre as atribuições de sua Diretoria Colegiada, autoriza o funcionamento das instituições financeiras e aprova eventuais associações.

\subsection{Realidade e cenário no mercado brasileiro}

O movimento de combinações no Brasil segue a lógica empresarial mundial apresentada anteriormente, porém alguns fatores específicos da realidade brasileira interferiram no processo: na década de 1990, a redução de barreiras econômicas ao capital estrangeiro, a privatização de empresas públicas, principalmente dos setores de infraestrutura e fabricação de matérias-primas e a estabilidade monetária adquirida após implantação do Plano Real acentuaram ainda mais o volume de fusões e aquisições no Brasil. A partir desse período, houve um intenso crescimento de grupos estrangeiros que entrou ou fortaleceu sua presença na economia brasileira, por meio de fusões e aquisições de companhias nacionais estabelecidas. (BARROS, 2003, p. 17; ROSSETTI, 2001, p. 67)

Outro aspecto relevante para o novo ciclo de fusões e aquisições foi a questão de mudança de geração. A década de 90 representou a chegada de novas gerações ao comando de grandes empresas familiares e, conforme os fundadores passavam seus negócios aos herdeiros, por falecimento ou aposentadoria, muitos optaram por vender ou se associar a outros grupos, por possuírem propósitos profissionais distintos dos negócios da família (ROSSETTI, 2001, p. 74). Na perspectiva dos adquirentes, as principais razões para os negócios recaíam sobre ganhos de mercado, de escala e ampliação de atuação geográfica, motivações embasadas pelo acirramento da competitividade em escala mundial. Muitas empresas buscavam se diversificar em suas linhas de produtos e serviços, enquanto outras empenhavam-se na verticalização de suas cadeias de negócios. 
Em uma pesquisa realizada por Barros (2003, p. 23) com as quinhentas maiores empresas brasileiras para mapear as operações combinatórias no país desde 1995, os executivos entrevistados apontaram que as principais motivações para as transações referiam-se ao aumento de participação de mercado, aquisição de marcas e penetração em novos mercados. Segundo Barros (2003, p. 23) "os fatores determinantes da aquisição influenciam em todas as etapas do processo, sobretudo na escolha da estratégia de integração da empresa adquirida".

Ainda de acordo com Barros (2003, p. 48), ao serem questionados sobre os principais fatores de sucesso, os executivos creditaram à comunicação com os diferentes stakeholders, à aceitação das gerências e equipes envolvidas, bem como à gestão cultural. Entretanto os mesmos líderes confirmam que a prática ainda está distante da realidade, pois grande parte das empresas ainda não planeja suas estratégias de integração com foco nas pessoas e na cultura organizacional. Segundo a autora,

[...] na grande maioria das vezes a empresa compradora impõe sua cultura e, em alguns casos, busca capturar alguns traços da empresa comprada, na tentativa de inseri-los em seu "modo de ser" ou "jeito de agir". Importam-se artefatos, traduzem-se discursos, adaptam-se comportamentos. Ao longo do tempo uma nova cultura será construída. As prioridades do top management, a decisão pela estratégia de comunicação, o conteúdo e a forma de distribuição das mensagens, o respeito demonstrado na efetivação da mudança e o modo de gerenciar desligamentos exprimem os valores da empresa. (BARROS, 2003, p. 49)

Outro ponto a ser considerado para o cenário brasileiro das fusões é o perfil cultural do brasileiro no ambiente corporativo. De acordo com Tanure e Cançado (2005, p. 14) o modelo de gestão brasileiro aponta perspectivas contraditórias, como a "flexibilidade para se adaptar a novas situações e a capacidade de lidar com a incerteza, aos quais se interpõe uma forte hierarquia. A flexibilidade se articula com um dos traços marcantes da cultura brasileira: a afetividade". Por outro lado, as autoras verificam também nas organizações brasileiras que "[...] a absorção de modernas técnicas de gestão apresenta certa submissão a processos importados. O comportamento de se orientar pela autoridade externa, presente ainda hoje nos hábitos sociais dos brasileiros - incluída a elite -, permite que se importem modelos sem adaptá-los às condições culturais“. Com isso, os discursos se tornam mais 
distantes das práticas, um dos graves entraves para a comunicação, principalmente em momentos de instabilidade, como nas fusões.

Constata-se, com isso, uma validação prática das percepções dos pesquisadores Appelbaum et al. (2000), Cartwright e Cooper (1996) e Marks e Mirvis (2010), apresentadas anteriormente, sobre a importância e urgência da comunicação centrada em todos os atores sociais, que permita atender ao interesses estratégicos e econômicos dos acionistas sem passar por cima das necessidades dos demais públicos envolvidos e interessados. A falta de foco nas pessoas, além de não contribuir para o bom andamento do processo integrativo e comprometer a relação entre as partes, nitidamente prejudica o atingimento dos resultados dos objetivos centrais a que se propõe a combinação, de obter ganhos maiores.

Mas antes de aprofundar o olhar para os processos comunicacionais em combinações empresariais e seus impactos na reputação corporativa, se faz necessário o estudo das organizações e da sociedade, por meio dos padrões culturais e políticos no ambiente organizacional, bem como de suas narrativas, para estabelecer um vínculo com a percepção da opinião pública, como será abordado no capítulo a seguir. 


\section{ORGANIZAÇÕES E SOCIEDADE}

De acordo com Nassar (2009, p. 62), as organizações são um sistema social e histórico que se comunicam e se relacionam de forma endógena e exógena e têm como característica comum o enfrentamento do desafio das mudanças, dentre outros aspectos. Mudanças estas que visam melhor adequação às transformações mercadológicas, econômicas, sociais, históricas, ambientais, culturais e comportamentais. Em que pese o cenário de constantes modificações, as organizações constroem e são construídas por seus padrões culturais e políticos.

Por outro lado, como dizia o poeta inglês John Donne "nenhum homem é uma ilha, fechado em si mesmo". Ou seja, tornar-se-ia estéril investigar as organizações dos pontos de vista cultural e político, sem adentrar a compreensão das pessoas na sociedade. Com isso, na sequência, será apresentada uma reflexão sobre os conceitos de públicos, opinião pública e sua influência nas organizações contemporâneas.

\subsection{Padrões culturais e políticos das organizações e interculturalidade}

Cultura remete a uma gama de significados distintos, dentre os quais sua percepção antropológica como o compartilhamento de um senso comum sobre a realidade, que atribui significados e valores à vida em sociedade, para os seres humanos. Edgar Schein define cultura como:

[...] conjunto de pressupostos básicos que um grupo inventa, descobre ou desenvolve ao aprender como lidar com problemas de adaptação externa e de integração interna, e que funcionam bem o suficiente para serem considerados válidos e serem ensinados aos novos membros como a forma correta de perceber, pensar e sentir em relação a esses problemas. (SCHEIN, 1984, p. 3)

A aplicação deste conceito ao ambiente corporativo define os padrões de crenças e valores que permeiam a organização e determinam seu jeito de ser e agir, bem como estabelecem as relações de poder entre pessoas e grupos, interna e externamente. Para Fleury e Fischer (2012, p. 12) cultura organizacional vai além dos significados, representando um recurso de comunicação e potencialmente de dominação: 
[...] o conjunto de valores e pressupostos básicos expresso em elementos simbólicos que, em sua capacidade de ordenar, atribuir significações, construir a identidade organizacional, tanto agem como elemento de comunicação e consenso como ocultam e instrumentalizam as relações de dominação. (FLEURY; FISCHER, 2012, p. 12)

O denominador comum destas definições estaria nos pressupostos básicos ou premissas que não necessitam de validação externa. Ao tomar as crenças de uma organização como verdades absolutas, as pessoas que a compõem, possuem um sentimento de pertencimento àquele ambiente, o que gera conforto, em meio ao caos das relações sociais. E no epicentro dos padrões culturais, em meio aos pressupostos básicos da organização, encontram-se as relações de poder, que são exercidas por meio da influência para determinadas ações e decisões, segundo o fundador do pensamento político moderno, Nicolau Maquiavel (1998).

Aqueles que, como os que mencionei, fazem-se príncipes mercê das suas virtudes conquistam com dificuldade os seus principados, mas com facilidade os podem conservar. As dificuldades que enfrentam para firmar-se nascem, em parte, dos novos ordenamentos e sistemas de governo que veem-se forçados a introduzir e que alicerçam os seus Estados e a sua segurança. Deve-se ainda considerar que não há coisa mais difícil a tratar, nem mais incerta a alcançar, nem mais arriscada a gerir que a efetiva introdução de uma nova ordem, porquanto aquele que a introduz terá por inimigos todos os que da velha ordem extraiam privilégios e por tímidos defensores todos os que das vantagens da nova poderiam usufruir. (MAQUIAVEL, 1998, p. 31)

Freitas (2007, p. 20) entende que um dos principais atributos da cultura é "dar estabilidade ao grupo, construindo um 'saber de receita', regras partilhadas em relação à forma de agir em certas situações, maneiras de perceber e o nível de importância das coisas“. Com isso, segundo ela, as mudanças trazem, além da dor, a necessidade de reorganizar os afetos, cujo "desafio para o indivíduo não se passa no nível consciente“.

Para Schein (1984, p. 4), a cultura organizacional deve ser analisada em três diferentes níveis de profundidade: os artefatos visíveis, os valores e os pressupostos básicos. Os artefatos representam indícios de grande visibilidade interna e externa à organização, como demonstrações físicas (logotipo, layout, vestuários, prédios), verbais (mitos, história, jargões, piadas, apelidos) e comportamentais (cerimônias, ritos, padrões de comunicação, tradições, recompensas, punições). Entretanto, a 
visibilidade se mostra inversamente proporcional à profundidade da análise deste patamar, que pode demonstrar facilmente do que é composto, mas raramente explica o porquê de seu comportamento. O segundo nível, dos valores compartilhados, é composto por regras não escritas, que permitem o entendimento das pessoas sobre o que se espera delas na organização. Por vezes, eles explicam os artefatos visíveis e são a porta de entrada para o terceiro nível: os pressupostos básicos, que determinam como as pessoas devem pensar, sentir e agir. Na medida que os valores são repetidamente incorporados ao comportamento, transformam-se em pressupostos inquestionáveis.

Estes modelos de vida compartilhados pelas pessoas que possuem vínculos com as organizações, aliados a fatores como bagagem cultural, religião, etnia e modos de distribuição de renda, reforçam uma homogeneidade cultural que predomina no ambiente corporativo e, por muitas vezes, geram a percepção de superioridade e estereótipos sobre elementos externos ao grupo (SCHULER, 2009, p. 248). Ao passo que os processos de transformações organizacionais abordados neste estudo pressupõem a desintegração dos modelos organizacionais existentes para a construção de uma nova corporação, delineia-se a perspectiva de um esforço profundo para que os padrões culturais antigos sejam substituídos e uma nova cultura possa emergir e se consolidar nas práticas e principalmente nas crenças. De acordo com Maria Ester de Freitas,

[...] ainda que estas mensagens (culturais) estejam gravadas apenas na superfície do cognitivo individual e coletivo, dificilmente elas poderão ser substituídas por outras mensagens contraditórias ou desqualificadoras, que impliquem aceitar que tudo que foi feito no passado foi um erro. Os indivíduos, mais que os grupos, têm enorme resistência a invalidar seu passado ou a tratá-lo como algo tolo e irrelevante; não é uma mera questão de má vontade, mas de terem sido psiquicamente "desenhados assim". (FREITAS, 2007, p. 39)

O que se compreende é que a resistência às mudanças por parte de pessoas ou grupos não deve ser encarada pela organização como um detalhe menos importante. Para Fleury e Fischer (2012, p. 68), se as premissas básicas da organização permanecem válidas ou internalizadas, não há estratégia, mesmo de excelência técnica, capaz de viabilizar as mudanças necessárias, sem que ocorra um profundo processo de reflexão e tratativas das razões para tais antagonismos. A questão central é lidar com o sentimento de perda das referências e anulação das 
histórias vividas. Cria-se um novo paradoxo: a memória da organização, até então preservada como um dos pilares de sua cultura, que Nassar (2009, p. 63) conceitua como um acervo de conhecimentos que "deve ser continuamente transmitido e reforçado para os integrantes da organização", pode se tornar momentaneamente a razão de desconforto no novo cenário, pois relembra promessas não cumpridas, papéis, autoridades e valores descartados. (FREITAS, 2007, p. 25)

A mudança não requer o apagamento do passado. Ao contrário, as histórias vivenciadas por ambos os lados oriundos da nova corporação podem e devem compor a construção do novo modelo. Candau (2011, p. 24) discorre profundamente sobre os conceitos de memória e identidade, tanto no âmbito individual como coletivo, e afirma que memória e identidade se conectam de forma indissociável, não havendo busca identitária sem memória e esquecimentos. Ainda que o autor considere reducionista definir a identidade como coletiva ou cultural, pois definiria o estado de um grupo inteiro quando apenas uma maioria compartilha tal estado, ele admite seu uso metafórico, como uma representação. E como consequência da pósmodernidade, com a queda do sagrado, das ideologias, da tradição e o desencantamento do mundo, vivemos um período de esgotamento e colapso das grandes memórias organizadoras. Situação que, por um lado, dificulta o enfrentamento da perda e da transformação, mas por outro, escancara a perda como condição única e inexorável do ser humano, seja da juventude, da saúde, dos amigos e família e finalmente da vida. Chega-se então à conclusão de que é preciso aceitar perder o antigo para que o novo possa nascer.

Paulo Nassar (2007, p. 186) reflete sobre a importância da singularidade das narrativas históricas das corporações.

Mais do que nunca, a questão do pertencimento, na sociedade atual, está posta como algo que diferencia e solidifica a relação dos públicos com a organização. Em um mundo em que é rapidamente banalizado pela massificação, pela utilização cotidiana, pelo excesso de exposição, uma diferenciação que nasce pela história de uma organização, é um atributo que poucos têm. (NASSAR, 2007, p. 186)

Com isso, torna-se viável propormos que a reconstrução identitária de uma organização passe pela rememoração de suas histórias, ainda que paralelas até um determinado trecho. Histórias que se encerraram em suas identidades do passado, para dar inicio a um novo ciclo de vida, sem que isso represente seu esquecimento. 
Na visão de Pettigrew (2012, p. 147) é possível gerenciar e até modificar a cultura organizacional, mas não sem um grande esforço. De acordo com o autor, a cultura organizacional não se refere somente às pessoas, seus relacionamentos e crenças, mas também a seus pontos de vista sobre os produtos da empresa, as estruturas, os sistemas, a missão da empresa, formas de recrutamento, socialização e recompensas. Ou seja, todos os elementos que são diretamente impactados e modificados nos processos combinatórios que compõem o objeto deste estudo. Além disso, Pettigrew destaca o fato de que muito da cultura organizacional é aceita implicitamente, sem questionamentos (taken for granted). E é, segundo ele, "extremamente difícil modificar coisas que são partes implícitas do pensamento e do comportamento das pessoas, e que raramente emergem explicitamente para discussão." Segundo Freitas (2007),

[...] vários estudos reconhecem a importância da convivência intercultural na vida das organizações que se misturam para formar uma nova e quase sempre se reconhecem a dificuldade em se preservar o que as organizações originais tinham de especial ou a dificuldade em como gerir a complementaridade na formação de uma nova identidade organizacional. (FREITAS, 2007, p. 71)

Neste ponto se torna fundamental aprofundar o olhar sobre a gestão do aspecto cultural nos processos combinatórios descritos no capitulo anterior. De acordo com Marks e Mirvis (2010, p. 189), os executivos consumidos com aspectos financeiros, estratégicos e operacionais historicamente deixam a integração cultural como prioridade baixa. No entanto, a maioria reconhece que subestimar a importância e a dificuldade de combinar as culturas existentes tem sido um enorme descuido em seus esforços. O choque cultural surge a partir da percepção das diferenças entre as empresas, seus estilos de lideranças, seus produtos ou serviços, sua reputação, seus funcionários, que deixam de ser simplesmente diferentes para se tornarem polarizados. Cria-se o clima de "nós contra eles" e surgem os estereótipos nas formas de ser e agir do outro lado. O choque cultural atinge seu ápice quando o outro lado é visto como inferior. As pessoas mostram um viés positivo para com os membros de seu antigo grupo e tendem a manter uma visão negativa sobre os membros do outro grupo, com o objetivo de melhorar a posição relativa de sua própria espécie. Para os autores, assim como as fusões são menos combinações de iguais e mais o predomínio de um lado sobre outro, a aculturação, que teoricamente deveria buscar a união balanceada das duas culturas, acaba sofrendo influência 
maior do lado que tende a se posicionar com superioridade, o que consideram prejudicial ao processo, já que a oportunidade de construir uma cultura compartilhada continua sendo um dos grandes benefícios da união de forças.

De acordo com Barros (2001, p. 133), o processo de aculturação pode ocorrer em três níveis:

- Assimilação cultural, no qual uma empresa absorve completamente a outra. Geralmente acontece em casos de aquisições e requer clareza e transparência de todos os envolvidos, para assegurar o respeito pelas pessoas, que saberão o que e quando as mudanças chegarão;

- Mescla cultural, quando os parceiros incorporam suas culturas de maneira equilibrada, tendo como premissa o diálogo permanente entre a alta gestão e os diferentes níveis hierárquicos. Seu grande risco é que um dos lados predomine sobre o outro e influencie mais na formação da terceira cultura. Costuma ser o modelo mais procurado nos casos de fusões, que empenhamse para a soma das qualidades de ambos os lados para o surgimento de uma nova cultura;

- Pluralidade cultural, quando diferentes culturas coexistem sem se sobrepor.

Como boa parte das combinações empresariais se dão entre organizações de diferentes nacionalidades, motivadas pelos ganhos mencionados no capítulo anterior, outro aspecto relevante no processo de aculturação diz respeito aos ambientes organizacionais que envolvam culturas nacionais distintas. De acordo com Hofstede (1997), os indivíduos possuem níveis de programação mental distintos para cada um dos grupos aos quais pertencem, como sua nação, sua religião, seu sexo, sua origem social e mais especificamente, a organização na qual trabalham. Com isso, o autor afirma que a programação cultural de uma pessoa passa antes pelos valores culturais de seu país, para, posteriormente, adentrar as manifestações culturais organizacionais, que tendem a ser menos a expressão de valores, como nos casos das culturas nacionais, e mais manifestações superficiais como símbolos, heróis e rituais comuns.

Um dos maiores desafios da interculturalidade, segundo Hofstede (1997), é alcançar o relativismo cultural, ou seja, fazer com que as pessoas suspendam seus juízos de valor quando lidam com grupos ou sociedades diferentes da sua: "Observamos o 
mundo através das janelas de uma casa cultural e agimos como se as pessoas de outros países tivessem alguma característica especial, enquanto nossa casa é normal". A compreensão intercultural não é impossível de ser alcançada, mas requer uma dose extra de boa vontade por parte das pessoas e, extrapolando para o ambiente corporativo, das organizações, que surge com a aceitação das diferenças.

\begin{abstract}
A consciência das limitações impostas por nossas programações mentais em relação aos outros pode ser adquirida e embora não se possa esperar que nos tornemos iguais, podemos aspirar a ser mais cosmopolitas na nossa forma de pensar. (HOFSTEDE, 1997)
\end{abstract}

Portanto, nos casos de combinações entre empresas de diferentes nacionalidades, as dificuldades relacionadas aos choques culturais tendem a vir em dose dupla, pois além das diferenças organizacionais, surgem desafios nas desigualdades de idiomas, regras, legislações e valores de cada nação.

E como fazer com que as culturas nacionais e organizacionais não se choquem ou que este choque não seja irreversível a ponto de prejudicar ou impedir o processo de integração corporativa? Uma vez que o funcionário tende a refletir o jeito de pensar e agir de quem é do seu grupo e principalmente de quem sempre o influenciou - seus gestores - , o primeiro passo na direção de uma aculturação menos problemática seria, pela lógica, o consenso aberto, explícito e amigável entre o novo grupo decisor da organização. Se os novos/antigos proprietários concordam na construção do novo modelo e aceitam abrir mão do status quo e de antigos formatos, torna-se mais fácil para que dirigentes e equipes sigam seu exemplo e abandonem antigos conceitos desalinhados dos novos propósitos. Schein (1984) atribui aos fundadores e aos principais líderes um papel de significativa relevância na construção da cultura organizacional, pois ao imprimirem sua visão de mundo para os funcionários, acabam por definir o papel da organização no mundo. $\mathrm{Na}$ mesma linha, Freitas (2007, p. 48) imputa aos fundadores um papel crucial: "quanto mais os líderes são tidos como visionários e determinados, mais eles são considerados heróis, podendo eventualmente, ser transformados em mitos".

Surge então um elemento decisivo para dar impulso ao processo de aculturação dos envolvidos: a comunicação. Barros (2001, p. 135) ressalta que "qualquer que seja o 
nível de aculturação ou mesmo as regras que orientam o comitê de integração, não há dúvidas sobre a importância a ser dada à comunicação" e complementa "não há conhecimento de nenhum caso de sucesso de gestão de encontro das culturas em processos de fusões e aquisições em que não tenha havido uma comunicação rápida e aberta". Indo além de seu papel mecanicista de fornecedora de informações, a comunicação deve ser aplicada em uma perspectiva estratégica, como alerta Marchiori (2009, p. 295), por meio de um processo de criação de conhecimento e estímulo ao diálogo.

[...] observar a produção de cultura é perceber como as pessoas se relacionam (pensam, sentem e interpretam diferentes realidades) no interior de uma organização. Se a cultura, na sua forma mais simples de expressão, pode ser interpretada como uma maneira particular de viver, a comunicação é seu fundamento. (MARCHIORI, 2009, p. 308)

$\mathrm{Na}$ mesma lógica Freitas (2006, p. 58) estabelece um forte vínculo entre comunicação e cultura, ao afirmar que "[...] a comunicação estabelece o diálogo da organização em âmbito interno e externo. Em âmbito interno, o diálogo se estabelece em consonância com a cultura organizacional",

Nos casos de comunicação intercultural, Fernandez Collado (2008) estabelece que, para o processo de intercâmbio de informações entre indivíduos e grupos que possuem diferenças culturais reconhecidas nas percepções e formas de conduta, é necessário que se perceba mais semelhanças do que diferenças entre as partes. É possível que as semelhanças não sejam tão evidentes como os fatores que diferem as organizações, mas elas devem ser minuciosamente estudadas e reforçadas. E mesmo as diferenças podem ser trabalhadas positivamente, a partir de elementos de complementaridade das divergências.

Na perspectiva de Schuler (2009, p. 269), todo processo de mudança organizacional implica a mudança cultural, somente possível por meio de uma intervenção comunicacional,

[...] em que as novas informações e as novas vivências funcionam como força transformadora, que necessita, contudo, de tempo, de sustentação e de perseverança para se manifestar como transformação efetiva. O processo implica uma mudança de visão, que incidirá sobre o entendimento da realidade - atitudes (crenças + emoção + ação), paradigmas, imagens e linguagem. (SCHULER, 2009, p. 269) 
É preciso quebrar os paradigmas antigos e transcender as estruturas, o que, segundo a autora, não ocorre sem algum nível de sofrimento. O medo da mudança de patamar e, com isso, do desconhecido que se apresenta como inevitável, aliado à vulnerabilidade de abrir mão do que já se conquistou, tornam-se peças de resistência para as mudanças culturais, mas podem ser superadas pela percepção de um novo conjunto de ganhos, necessidade e consciência. Novas relações de poder precisam ser estabelecidas entre os indivíduos, em meio às incertezas inerentes à mudança. Neste sentido, comunicação e cultura organizacional caminham lado a lado, entrelaçadas pelo propósito de, juntas, construírem as bases de entendimento e compreensão mútua para a construção da nova realidade organizacional, que será vivenciada não só pelos elementos internos, como a alta cúpula e os funcionários, mas todas as esferas da sociedade que serão impactadas por sua existência e atitudes.

Com isso, antes do estudo abarcar a temática da comunicação e das relações públicas, se faz necessária uma revisão dos conceitos de público e opinião pública, bem como a reflexão sobre processo de influência da opinião pública nas organizações em transformação, que serão apresentadas a seguir.

\subsection{Opinião Pública: natureza e conceitos}

Opinião pública e públicos: o que estas nomenclaturas, que carregam similaridades em suas grafias, têm em comum? De que forma se entrelaçam e se relacionam? Primeiro conceito a ser analisado, o termo "público" opõe-se ao privado, ou seja, aquilo que é notório ou conhecido de todos. Simões (1995) define público como um conjunto abstrato de pessoas com interesses comuns entre si e referentes à organização. Como tal, não chega a se caracterizar como grupo psicológico e muito menos como organização, pois seus membros, as pessoas, não chegam a relacionar-se entre si. Para Andrade (2001, p. 14), público representa um grupo de pessoas ou grupos sociais, presentes ou ausentes fisicamente, que pensam e refletem sobre os problemas colocados na discussão pública, o que pressupõe uma ação racional, diferente da multidão e da massa, que agem impulsivamente. 
A partir das análises de conceitos propostos por Gabriel Tarde (1990, apud FRANÇA, 2012, p. 12) - que diferencia multidão de público e o correlaciona à fragmentação das camadas da sociedade, em uma visão de mundo ainda não contaminada pela sociedade da informação e do conhecimento - e Alvin Toffler (1995 apud FRANÇA, 2012, p. 14) - que destaca a mobilidade do conceito de público decorrente das transformações na natureza do poder desde a sociedade agrária até a sociedade pós-industrial, França (2012, p. 15) afirma que a base de justificativa é o comportamento do público, em razão de interesses e controvérsias, mas não por seus vínculos nos negócios de uma organização. Toffler (1995) resume o desenvolvimento da comunicação partindo do foco para o indivíduo, depois para as massas, e em seguida são dirigidas aos públicos segmentados diferenciados. Tarde (1990) aponta que o conceito apresenta ampla variedade de sentidos, a partir de uma evolução histórica.

A partir de então, França (2012, p. 62) busca uma conceituação que considere as transformações organizacionais e exigências do mundo globalizado, que não se restrinja ao contexto sociológico ou à resolução de conflitos, e cria uma nova classificação pautada por três critérios: grau de dependência jurídico ou situacional da organização de seus públicos para sua constituição, existência e sobrevivência; grau de participação, maior ou menor nos negócios da empresa, na defesa de seus interesses e na sua promoção institucional ou mercadológica; e grau de interferência dos públicos sobre a organização e os seus negócios não participando da constituição ou da manutenção da empresa. A conceituação lógica de França permite mapear os públicos, definir suas relações com as organizações, analisar a interdependência dos públicos e das organizações, e assim, de acordo com o autor, estabelecer programas de relações públicas e de comunicação adequados aos relacionamentos de uma empresa com seus públicos de interesse. Entretanto, há de se considerar que o contexto contemporâneo da sociedade informacional nos impele a um papel cada vez mais multifacetado, que se contrapõe a uma delimitação única de classificação perante as organizações com as quais nos relacionamos.

Já o estudo conceitual da opinião pública remete a uma ampla gama de abordagens que remontam a períodos distantes da realidade contemporânea. A frase em latim 
Voz populi, vox $D e i^{1}$, difundida na Idade Média, já remetia à importância da opinião das massas e sua influência no comportamento geral da sociedade.

Entretanto, de acordo com Harold Childs (1967), somente em meados do século XVIII, a expressão opinião pública passou a ser analisada por cientistas políticos e sociais, como Jean Jacques Rousseau (2011, p. 36), que a vincula à vontade geral de um povo.

[...] A essas três espécies de lei se junta uma quarta, a mais importante e todas: a que não se grava no mármore nem no bronze, mas no coração dos cidadãos; que faz a verdadeira constituição do Estado; que assume todos os dias novas forças; que, quando as outras leis envelhecem e se extinguem, as reanima ou as supre, conservando um povo no espírito de sua instituição e substituindo imperceptivelmente a força do hábito pela da autoridade. Falo das práticas, dos costumes e sobretudo da opinião; parte desconhecida de nossos políticos, mas da qual depende o sucesso de todas as outras; parte da qual o grande Legislador ocupa-se em segredo, enquanto parece limitar-se a regulamentos particulares que são apenas o cinturão da abóbada, da qual os costumes, mais lentos em nascer, formam enfim o inabalável centro. (ROUSSEAU, 2011, p. 36)

$\mathrm{Na}$ visão de Childs, fundador da Public Opinion Quartely, uma das revistas cientificas mais respeitadas na área de comunicação e opinião pública, a expressão representa uma coleção de expressões individuais.

A opinião pública, refere-se sempre a um grupo de opiniões individuais, e não a uma coletividade mística que paira no ar por sobre as nossas cabeças. Para descobrir qual é um determinado estado da opinião pública, portanto, temos de colecionar opiniões de indivíduos. Este ponto não mereceria destaque especial, a não ser por terem alguns escritores pensando em termos de uma "mente de grupo", completamente separada e distinta das mentes das pessoas tangíveis. (CHILDS, 1967, p. 77)

Ainda segundo o autor

Opinião pública é qualquer coleção de opiniões individuais, independentemente do grau de concordância ou uniformidade. O grau de uniformidade é um assunto a ser investigado, e não algo a ser fixado arbitrariamente, como condição para a existência da opinião pública. (CHILDS, 1967, p. 77)

\footnotetext{
${ }^{1}$ Tradução livre da autora: A voz do povo é a voz de Deus.
} 
No sentido oposto, Bourdieu (1973, p. 1294) alerta que é preciso muito cuidado para não transformá-la simplesmente na soma ou média das opiniões individuais. De acordo com o sociólogo francês, a opinião pública surge de opiniões já constituídas e grupos de pressão mobilizados em torno de interesses explícitos. Particularmente nas situações de crise, as pessoas se encontram diante de opiniões constituídas e sustentadas por grupos. Portanto, ao escolher entre duas opiniões, torna-se inevitável a polarização/politização de se escolher entre tais grupos. Nota-se neste conceito a influência da questão das relações de poder, apresentada no capítulo anterior.

Para Andrade (2003, p. 4), tanto o interesse público como a opinião pública se referem às formas de comportamento coletivo dos agrupamentos espontâneos, em especial, os públicos, não necessariamente a opinião da maioria. Segundo o autor, "a opinião pública está em constante processo de formação em direção a um consenso completo, sem nunca alcançá-lo." O desenvolvimento da opinião pública exige quatro fases: a primeira fase constitui-se pelo surgimento de uma questão de interesse geral, que não pode ser solucionada por padrões e normas culturais; na segunda fase, a controvérsia é definida mediante debates; a terceira fase delimita a controvérsia por meio de propostas ou soluções e dá início a discussão pública; e na quarta e última etapa, as pessoas ou grupos chegam a um consenso, ou seja, uma mescla das opiniões individuais ou dos grupos presentes.

Entretanto, há que se considerar que o comportamento do ser humano nem sempre decorre somente do conhecimento real sobre a situação que ele vivencia. Muitas vezes, sua postura frente a uma circunstância se dá menos pela verdade dos fatos e mais pela imagem que tal pessoa construiu sobre o determinado assunto, o que, segundo Walter Lippmann, seria o ponto de partida para a construção da opinião pública.

[...] Aqueles aspectos do mundo exterior que têm a ver com o comportamento de outros seres humanos, na medida em que o comportamento cruza com o nosso, que é dependente do nosso, ou que nos é interessante, podemos chamar rudemente de opinião pública. As imagens na cabeça destes seres humanos, a imagem de si próprios, dos outros, de suas necessidades, propósitos e relacionamento, são suas opiniões públicas. Aquelas imagens que são feitas por grupos de pessoas, ou por indivíduos agindo em nome de 
grupos, é Opinião Pública com letras maiúsculas. (LIPPMANN, 2008, p. 40)

Como as pessoas definem o entendimento dos fatos em função de seus conhecimentos prévios, o que estiver fora deste escopo de conhecimento naturalmente é classificado como algo a ser rechaçado, rebatido, condenado. Para Lippmann (2008, p. 120), "o padrão de estereótipos no centro de nossos códigos determina largamente que grupo de fatos que nós veremos, e sob que luz nós os enxergaremos", O que endereça ao sujeito pensante descrito por Baldissera (2009, p. 142) como produtor e produto de seu pensamento e de suas construções. De acordo com o autor, "o mundo não é real, o mundo é concreto, a realidade é apenas uma conclusão do imaginário tecido pelas lentes da percepção".

Em que pesem as diferentes abordagens teóricas sobre opinião pública, é possível equalizá-las na seguinte proposição: a opinião pública decorre dos entendimentos individuais ou de grupos sobre determinado assunto, ainda que não se determine se fazem parte de seus valores intrínsecos ou como consequência de repercussões midiáticas. Portanto, sua visão de mundo e seus interesses, sejam pessoais ou coletivos, tornam-se decisivos para qual caminho a opinião seguirá, mesmo que haja fragmentos exclusivos de entendimento para cada ser humano, pois como afirma Lippmann,

[...] a mesma estória não é nunca igual para todos os ouvintes. Cada um entrará nela levemente em diferentes momentos, já que duas experiências não são exatamente iguais; cada pessoa a reapresentará de seu próprio jeito, e a tratará com seus próprios sentimentos. (LIPPMANN, 2008, p. 158)

Junte-se a este cenário o presente momento da sociedade contemporânea, marcado por uma série de mudanças de paradigmas científicos, socioculturais, jurídicos, políticos, econômicos e comunicacionais e que exige dos articuladores dos poderes econômico e político uma postura de comunicação, dialogo e negociação. Na visão de Andrade, a opinião pública hoje em dia é consideravelmente mais sensível e rigorosa.

Devido ao intercâmbio permanente e amplo de conhecimentos e informações entre todas as partes do mundo, por força do espetacular desenvolvimento dos meios de comunicação, não se pode negar que a opinião pública é hoje mais sensível e exigente. Por outro lado, o 
fluxo contínuo de notícias, propostas e interpretações colocam o homem moderno em situação difícil para distinguir a verdade da mentira. (ANDRADE, 2003, p. 9)

Em seu livro "Estratégias de Comunicación" Perez (2008) considera que nunca houve um momento de tão vertiginosa importância para a opinião pública e gestão estratégica da imagem, como nos dias atuais. Esse novo poder da comunicação midiática deve advertir aos receptores de que não há como receber informações verdadeiramente imparciais, objetivas e não intencionais. Há de se considerar também que este é um cenário altamente competitivo, informacional, fragmentado, globalizado e organizado em rede, marcado pelas contradições do paradigma da complexidade. Diante deste panorama, torna-se imprescindível uma análise acurada sobre a influência que a opinião pública pode vir a exercer, em maior ou menor grau, nas organizações contemporâneas.

\subsection{Influência da opinião pública nas organizações}

Uma das principais características da sociedade no século XXI é a descentralização do poder de fala, antes restrito às grandes instituições, e agora passível de compartilhamento por todo e qualquer cidadão inserido no contexto social e tecnológico. Qualquer um de nós, seres humanos contemporâneos, pode criar um manifesto, traduzir para meia dúzia de idiomas e pulverizar na mídia online e off-line, por meio de estratégias de relações públicas. Entretanto, os antigos quinze minutos de fama que tantos almejam podem agora se resumir a pouco mais de quinze segundos ou cento e quarenta caracteres nos tempos atuais.

Neste cenário, as organizações, como reflexo da sociedade em que estão inseridas, se antes focavam sua visão de mundo em si próprias, agora se permitem (ou são exigidas para) uma atuação participativa e compartilhadora de ideias, perante os

demais atores sociais. A procura das organizações é pelo diálogo constante e ponderado, que como alertam Marques e Mafra (2013, p. 83), não deve buscar apenas a neutralização das divergências, mas "um espaço efetivo de trocas, de tratamento de problemas coletivos e de verificação conflitiva de uma pretensa igualdade entre os interlocutores", Segundo os autores, há muito o que caminhar antes de se afirmar um equilíbrio nesta relação dialógica, ainda permeada por 
relações ocultas de controle, poder e persuasão por parte das corporações.

O desafio atual das organizações é equilibrar percepções, para que seus interesses sejam considerados, ao mesmo tempo que as demais opiniões não sejam descartadas e com isso, volte para si a imagem de autoritarismo do modelo de gestão tradicional. Reflexão que nos remete à ambiguidade entre o ser e parecer, que se amplia nas palavras de Maquiavel.

[...] Os homens, in universali, mais julgam pela visão que pelo tato, uma vez que todos podem facilmente ver; somente uns poucos sentir. Cada qual vê o que parece ser; poucos têm o sentimento daquilo que de fato és; e estes poucos não ousam contrapor-se à opinião dos muitos[...] (MAQUIAVEL, 1998, p. 102)

Remetendo às organizações contemporâneas, a estas não é dado mais o direito de agirem com seriedade somente de seus portões para dentro. É preciso ir além e fazer com que todos os públicos que componham sua teia de relacionamento, conheçam, acreditem e participem da construção de seus valores, sejam morais, como honestidade e integridade; ou técnicos, como sua competência.

É neste ponto que entra em ação o trabalho estruturado e planejado das relações públicas. De acordo com Farias (2009b, p. 94), a opinião pública favorável é um dos mais importantes objetivos que uma organização estabelece para sua estratégia de relações públicas e, sem dúvida, o que se deseja por intermédio de ações de relacionamento com a imprensa. O autor traz à tona a discussão sobre o papel da imprensa como um canal de formação de opinião e as possíveis estratégias das organizações para estabelecer e intensificar o relacionamento com a mídia, mas alerta sobre a mítica supervalorização da imprensa na formação da opinião pública.

[...] A mídia, de forma geral, e a imprensa, de forma específica, têm forte influência sobre o modo como os assuntos ficarão em suspenso no oxigênio social, sem, contudo, terem a capacidade - ao menos de forma exclusiva - de determinar a percepção sobre o todo dos temas. (FARIAS, 2009b, p. 94)

Ou seja, estruturar diálogo e relacionamento com a mídia pode ser um começo significativo no processo de formação de opinião pública, porém não sustenta como estratégia única, lembrando que o conceito da comunicação integrada preconiza a convergência das áreas da comunicação mercadológica, institucional, interna e 
administrativa, por meio de múltiplas abordagens e públicos a serem trabalhados (KUNSCH, 2003, p. 150). Lippmann (2008) vai mais longe na crítica à imprensa como base única para a formação da opinião pública.

[...] A imprensa não é substituta para as instituições. É como um raio de holofote que se move sem descanso, trazendo um episódio e depois outro fora da escuridão à visão. Os homens não podem fazer o trabalho do mundo através desta luz somente. Eles não podem governar a sociedade por episódios, incidentes e erupções[...] $O$ problema é mais profundo do que a imprensa, e assim também o é o remédio. Ele fica na organização social baseada num sistema de análise e registro, e em todas as consequências daquele princípio; no abandono da teoria do cidadão todo-poderoso, na descentralização da decisão, na coordenação da decisão por registro comparável e análise. (LIPPMANN, 2008, p. 308)

Para Farias (2011, p. 114) a formação da opinião pública se dá como consequência da construção de uma boa ou má percepção dos públicos, a partir da influência de três macro atores: o governo, responsável pela legalidade constitutiva da organização, por meio das autorizações para funcionamento; a mídia, que pode assegurar ou não sua legitimidade; e por fim, a relação de convívio e vínculo de confiança com os demais stakeholders (clientes, acionistas, funcionários, sindicatos, entidades, comunidades de entorno, concorrentes, parceiros, entre outros), conforme exemplifica o quadro 2, abaixo.

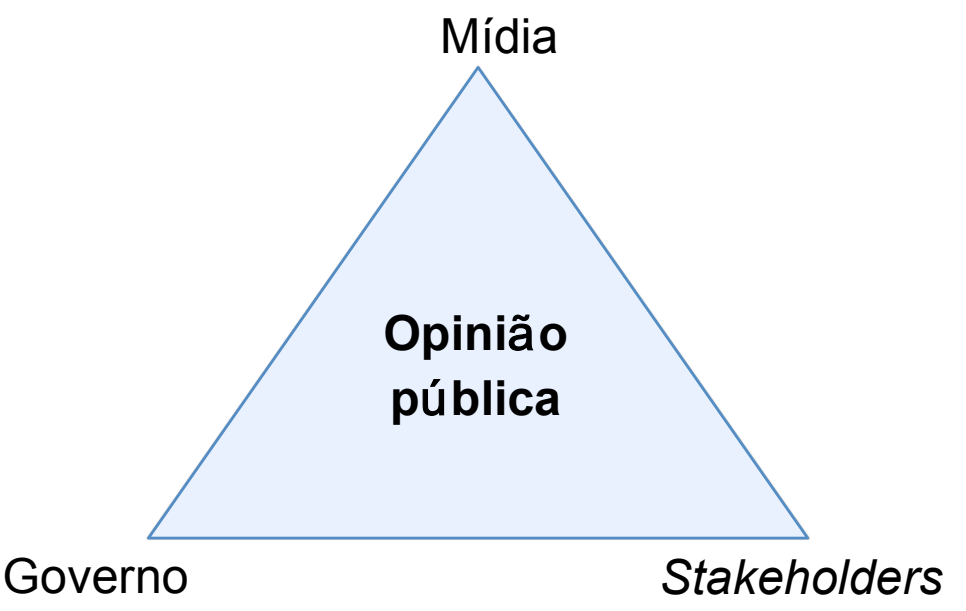

Quadro 2 - Impacto dos públicos sobre a percepção da organização (FARIAS, 2011, p 112)

Com base nas relações que constroem com os elementos dos vértices deste triângulo, as organizações visam aumentar sua capacidade de influência, seja ela conceitual, por meio das percepções destes públicos acerca de suas qualidades; ou 
em uma visão pragmática, como consequência de eventuais decisões de tais públicos que impactem em seu sucesso ou fracasso. Ou seja, as percepções da opinião pública sobre uma determinada organização, percepções estas que podem ser convertidas na definição de reputação proposta por Barnett (2006), conectam-se direta e intrinsecamente à efetividade do trabalho de relações públicas de estabelecer e manter compreensão mútua com os públicos aos quais está ligada.

Entretanto, por todas as complexidades inerentes à formação da opinião pública já mencionadas anteriormente, não se deve resumir este processo a uma fórmula simplista "organização + relações públicas = opinião pública favorável". Tanto para o ponto de vista da organização como da opinião pública, existem diversas variáveis de contexto que interferem em suas percepções e comportamentos. Um dos exemplos é a teoria da espiral de silencio da alemã Elisabeth Noelle Neumann. Segundo ela, as pessoas se calam à medida que possuem uma opinião diferente da maioria, isoladas pelo medo da diferenciação. Com isso, quanto mais as opiniões majoritárias reverberam, menos se escuta as opiniões minoritárias. (HOHLFELDT; MARTINO; FRANÇA, 2001, p. 113)

Ao fim e ao cabo, ao abordar organizações, públicos e opinião pública, fala-se de pessoas, com suas emoções, vivências, preconceitos e visões de mundo. Estabelecidos os parâmetros conceituais sobre os processos transformacionais e seus atores sociais, organizações e públicos, o estudo parte para o entendimento do ultimo pilar na construção estrutural do estudo: as relações públicas e a gestão reputacional das organizações. 


\section{RELAÇÕES PÚBLICAS NA GESTÃO REPUTACIONAL DAS ORGANIZAÇÕES}

\subsection{Relações Públicas: definição e atribuições}

Diversos especialistas abordam o escopo e entendimento das relações públicas. A base do capítulo que se apresenta a seguir situa-se na conceituação de relações públicas enquanto área de estudo e atividade e visa não esgotar as diferentes percepções sobre o tema, mas buscar reflexões de autores consagrados que possibilitem sua interligação com as temáticas apresentadas nos capítulos anteriores.

Primeiramente, se faz necessário o entendimento das diferenças conceituais entre comunicação organizacional e relações públicas, áreas próximas e imbricadas, porém distintas, ainda que a percepção de mercado brasileiro encontre certa dificuldade em diferenciá-las. Para Margarida Kunsch (2003, p. 149) a comunicação organizacional é a disciplina que estuda de que forma se processa o fenômeno comunicacional dentro das organizações e no âmbito da sociedade global. Em paralelo, a autora afirma que o objeto de estudo das relações públicas divide-se em organizações e seus públicos, que se inter-relacionam e interagem constantemente. As relações públicas trabalham na promoção e administração do relacionamento entre organização e públicos, bem como da mediação de seus possíveis conflitos, por meio de estratégias e programas comunicacionais, que visam harmonizar interesses de ambos os lados, estabelecendo uma relação de confiança mútua.

De acordo com Farias (2009a, p. 57), comunicação organizacional corresponde à área do pensamento responsável pela permanente busca de teorias comunicacionais e transformação dessas teorias pelos agentes da comunicação, representados pela área de relações públicas, que são as teorias, as estratégias e os conjuntos de técnicas e de instrumentos - utilizados de modo articulado entre si, por meio do planejamento estratégico - que buscam opinião pública favorável a dado objetivo. Com isso, em uma visão simplificada, a primeira corresponde ao "fazer saber" enquanto a segunda representa o "saber fazer". 
Roberto Porto Simões (1995) traz para sua conceituação de relações públicas a questão do poder, definindo-a como a gestão da função política da organização, que visa ocorrer e ser percebida em prol dos benefícios de interesses comuns que possui com seus públicos. Portanto, mais do que administrar a comunicação, o autor entende que a essência da atividade resulta na administração de conflitos e das relações de poder. França (2006) reforça a questão, ao estabelecer

a necessidade de focalizar com maior propriedade os relacionamentos como foco primordial de uma atividade que tem sua razão de ser no planejamento e na gestão de politicas permanentes das relações da organização com os públicos de interesse. (FRANÇA, 2006, p. 3)

Em uma interpretação menos dialógica, Fortes (2003, p. 31) remete às relações públicas a incumbência de formar públicos e lidar com a opinião pública, sendo esta a "causa e efeito das atividades de relações públicas, pois o poder da opinião pública afeta as decisões gerenciais e é função dos relações públicas identificar esta opinião e comunicá-la e explicá-la para a administração".

Abrindo o leque das conceituações para estudos internacionais, destacam-se os quatro modelos de relações públicas identificados pelos pesquisadores James Grunig e Todd Hunt, em 1984 e a Teoria Geral de Excelência em Relações Públicas, desenvolvida por Grunig, em 1992. (GRUNIG; FERRARI; FRANÇA, 2011) Dentre os quatro modelos - agência de imprensa/divulgação, focado na divulgação por técnicas de propaganda; informação pública, que visa disseminar informações objetivas; assimétrico de duas mãos, baseado no dialogo persuasivo; e simétrico de duas mãos, que visa utilizar a comunicação como recurso para administrar conflitos e aperfeiçoar o entendimento com os públicos, por meio do diálogo transparente e equilibrado -, o último se aproxima das percepções de Kunsch (2003, p. 89), França (2006) e Simões (1995), e sobressai como a base para a teoria da excelência, que seria desenvolvida na década seguinte. Segundo Grunig,

A área de Relações Públicas exerce um papel gerencial estratégico além da função técnica da comunicação. Recusando-se a ser uma mera função de transmissão de mensagens que tentam defender a organização de seu ambiente, as relações públicas empenham-se em construir alianças com os públicos estratégicos no seu meio ambiente e dar-lhes voz no processo decisório que os influencia. (GRUNIG; FERRARI; FRANÇA, 2011, p. 40) 
No estudo da excelência em relações públicas, o autor apresenta dez princípios que impulsionam os valor da comunicação para as organizações, agrupados em sete categorias, como se vê no quadro 3.

\section{Categorias}

I. Empoderamento da função das Relações Públicas

\section{Princípios}

1. O alto executivo de Relações Públicas participa dos processos de gestão estratégica da organização (tomada de decisões) e os programas de comunicação são desenvolvidos para públicos estratégicos identificados como parte desse processo.

2. O alto executivo de Relações Públicas é membro da coalizão dominante da organização ou se reporta diretamente aos diretores executivos que pertencem a ela.

3. A diversidade está incorporada em todos os papéis de relações públicas.

4. A unidade de Relações Públicas é chefiada por um gerente, e não por um técnico.

5. O alto executivo de Relações Públicas ou outros na unidade de Relações Públicas devem ter conhecimento necessário para o papel gerencial. Não sendo assim, a função de comunicação não terá o potencial para tornar-se uma função gerencial.

6. Função de comunicação integrada.

7. Relações Públicas como função gerencial separada de outras funções organizacionais

8. Programas de comunicação desenvolvidos para públicos específicos são baseados no modelo simétrico ou de motivos mistos.

9. O alto executivo de Relações Públicas ou outros na unidade de Relações Públicas devem ter conhecimento necessário para o modelo simétrico de mão dupla, ou então a função de comunicação não terá potencial para exercer esse modelo de excelência.

V. Características de programas individuais de comunicação

VI. Ativismo e o contexto ambiental para a excelência

VII. O contexto organizacional de relações 10. A cultura organizacional participativa públicas excelentes colabora para a comunicação excelente.

Quadro 3 - Quadro organizado pela autora, a partir da teoria de excelência em Relações Públicas (GRUNIG; FERRARI; FRANÇA, 2011) 
No entendimento de Kunsch (2006, p. 43), a teoria da excelência nas relações públicas pode ser sintetizada no fato de seus atributos serem o valor que a alta administração destina à comunicação e o papel do executivo de comunicação como tomador de decisões, e não como técnico, com base em planejamento estratégico, pesquisa, análise da cultura organizacional, valorização da cooperação e inovações. Para viabilizar o planejamento da comunicação excelente, a autora resgata a importância do equilíbrio entre as necessidades da organização com a de seus principais públicos.

Entretanto, como já aponta Grunig (2011, p. 36) por meio dos demais modelos mapeados - de agência de imprensa, de informação pública e o assimétrico de duas mãos -, há de se destacar que este papel estratégico das relações públicas, na prática, não surgiu com o início das atividades por Ivy Lee, no final do século XIX. Naquele momento, empresários norte-americanos buscavam apoio da opinião pública, após situações extremas de crises com imprensa e sindicatos. Em que pese Lee ter se tornado o primeiro profissional reconhecido mundialmente pelo trabalho de recuperação da credibilidade do magnata John D. Rockfeller e publicado a declaração de princípios das relações públicas, na qual defendia que a responsabilidade pública dos profissionais fosse além das obrigações para com o cliente, durante décadas a atividade ficou marcada muito mais por seu caráter instrumental e persuasivo do que pela capacidade estratégica de gerenciar relacionamentos.

Segundo Andrade (2001, p. 34), Edward Bernays, considerado para muitos estudiosos como o pai das relações públicas, a definia como "a edificação do apoio público para uma atividade, causa, movimento ou instituição, por meio da informação, persuasão e do ajustamento". Bernays baseava-se em estudos de seu tio Sigmund Freud sobre a irracionalidade das pessoas, para justificar a manipulação de suas ações e decisões.

Com todas as transformações sociais do século $\mathrm{XX}$, em especial sua última década, um novo contexto empresarial que começa ser pautado por conceitos de ética e cidadania e modelos comunicacionais mais complexos, quando as relações públicas se viram obrigadas a extrapolar sua função instrumental para assumir um papel 
estratégico com ferramentas integradas, objetivos amplos e que posicionasse todos os atores no palco das interações sociais. A comunicação, posicionada como ambiente e fluxo privilegiados para as inter-relações e interações culturais/identitárias e como disputa dialógico-recursiva de sentidos e não como um processo autoritário e unilateral (BALDISSERA, 2009, p. 136), deixa de atuar somente pela perspectiva mecanicista, cujo foco concentra-se na transmissão utilitária de mensagens por meio de canais pré-determinados, para exercer sua atuação estratégica. (PUTNAM, 1987) A expressão comunicação estratégica deve ser compreendida em duas perspectivas: pelo olhar da organização, que representa o alinhamento da comunicação aos objetivos e estratégias do negócio. Por outro lado, há a perspectiva dos atores sociais, que enxergam a comunicação estratégica como mediadora das relações e dos ambientes interno e externo. (OLIVEIRA; PAULA, 2007)

Para aprofundar o entendimento do tema estratégia, se faz necessário seu resgate conceitual. A palavra estratégia vem do grego strategos e em tradução literal seria "arte de comandar um exército". Como bem escreveu o estrategista chinês Sun Tzu há mais de 2000 anos no tratado "A arte da guerra", a estratégia deve respeitar quatro princípios: escolha do local de batalha, concentração de forças, ataque e forças diretas e indiretas. Em analogia com a estratégia corporativa, estes princípios corresponderiam à seleção de mercado, aos recursos, às ações competitivas e à gestão de contingências. Amplamente utilizado por forças militares, o planejamento estratégico teve seu modelo adaptado para o universo empresarial no final da década de 1950, tornando-se o conjunto de objetivos e metas de negócios das organizações, bem como a formula para atingi-los.

Sob o olhar comunicacional de Rabaça e Barbosa (2001), o planejamento estratégico representa o ato de relacionar e avaliar informações e atividades - de forma ordenada e com lógico encadeamento entre elas - a serem executadas num prazo definido, visando à consecução de objetivos pré-determinados. Dentre os inúmeros tipos de planejamentos aplicáveis às mais variadas áreas das organizações, Kunsch (2003, p. 214) destaca três modelos essenciais no contexto aplicado ao planejamento de comunicação e relações públicas: estratégico, tático e operacional. O planejamento estratégico responde pelas grandes decisões da 
organização como um todo, enquanto o planejamento tático restringe-se a setores ou áreas em busca de respostas a demandas imediatas. Por ultimo, o planejamento operacional instrumentaliza e formaliza o processo bem como sua metodologia e controla a execução.

A elaboração de um planejamento estratégico de relações públicas requer uma etapa prévia de identificação da realidade organizacional, a partir do levantamento de dados formais e informais, com destaque para as análises organizacional e ambiental, que são estudadas à luz das forças e fragilidades identificadas. Com a composição do diagnóstico, torna-se possível a identificação dos públicos e determinação dos objetivos e metas, respaldados por relevância e assertividade. A partir de então, são adotadas as estratégias compostas por planos de ação e de contingência, definição de recursos, fixação das técnicas de controle e avaliação dos resultados. Para Farias (2011, p. 51), o planejamento estratégico comunicacional se reflete na necessidade de obter melhores resultados com menos esforços, na potencialização de resultados e principalmente na transformação de imagem em reputação, construída em longo prazo e por meio de relacionamentos estáveis. Com isso, é possível inferir que as relações públicas, quando utilizadas em seu papel estratégico e coordenado, de forma a dialogar com equilíbrio e transparência entre organização e seus públicos, tornam-se diretamente responsáveis pela geração de reputação corporativa.

\section{Relações públicas nos processos de fusões}

Dentre os escassos estudos sobre as relações públicas nos processos de fusões, constam a tese de doutorado da pesquisadora espanhola Anabela Felix Mateus (2012), que investigou a comunicação interna de fusões em empresas seguradoras portuguesas na década de 1980 e a tese de doutorado de Adriana Casali (2006), com a abordagem da comunicação nos processos internos às organizações envolvidas em fusões e aquisições internacionais. Ambas referem-se somente aos público interno das organizações, excluindo da análise das demais relações que a organização possui externamente. Casali (2006, p. 170) compreende que o estudo da comunicação interna nos casos de fusões e aquisições deve ser realizado por meio da observação das interações ocorridas, "identificando os processos e 
momentos dessa estratégia em que a comunicação organizacional manifesta-se de forma constitutiva ou informativa“. Para Felix Mateus (2012), ao lidar com o discurso das mudanças, o profissional de relações públicas passa a gerir tantos antagonismos que a integração e a coesão tornam-se conceitos sem significados.

Seu papel tem que ir, obrigatoriamente, mais longe. Tem que
aprender a combinar diferenças e antagonismos para adequar o seu
discurso, reconhecendo a impossibilidade na estratégia da coesão e
da integração no recente convívio do pluralismo e do individualismo,
agora muito mais pautados por critérios de flexibilidade, efemeridade
e despadronização. (FELIX MATEUS, 2012, p. 1031)

Ao discorrer sobre os predicados do discurso como um instrumento de gerenciamento de conflitos, Putnam (2008) afirma que é preciso criar um fluxo constante de informações e estabelecer uma relação pautada pela confiança no sistema de comunicação da organização. Assim, segundo a autora, nos momentos de grandes mudanças como as fusões, às organizações cabe aumentar o fluxo de informações, por meio de diversos canais e pontos de discussão, além de estabelecer politicas de portas abertas para todos os seus stakeholders, com mensagens transparentes e estratégicas.

Anderson, Havila e Nilsson (2012, p. 269) reforçam este posicionamento, alertando que o diferencial se dá por meio de uma abordagem multi-stakeholder, que deve envolver vários grupos de interesses de ambas as empresas oriundas, que precisam ter acesso aos prós e contras das mudanças ocorridas, para com isso, elaborar suas próprias ações e reações. Segundo os autores, existem dúzias de objetivos diferenciados nos processos combinatórios, que impactam seus públicos de interesse de maneiras variadas, portanto a abordagem deveria ser customizada caso a caso. Entretanto, pesquisas apontam majoritariamente para o olhar das empresas envolvidas, e raramente para as necessidades de seus públicos. A lógica dos estudos realizados neste caminho aponta os benefícios de maior envolvimento dos stakeholders nos processos de fusões e aquisições: ampliação da rede de negócios, visibilidade aos conflitos ocultos e aprimoramento do entendimento do processo de maneira holística. 
Freitas (2006) assume um tom mais crítico, ao questionar a contribuição efetiva dos pesquisadores de comunicação e cultura organizacional para o cenário contemporâneo de mudanças.

As organizações no Brasil apresentam claros sinais de mudanças. São fusões, incorporações, falências, ou seja, um cenário de nítidas mudanças que colocam a questão do emprego acima das análises do clima, do ambiente ou da cultura organizacional.[...] Diante da realidade fica ilusória a discussão teórica das questões da comunicação e da cultura organizacional. Por outro ângulo, de nada adianta autores festejados no mundo acadêmico apresentarem críticas e mais críticas contra os atuais modelos de gestão, ou de organizações, sem propostas consistentes que indiquem caminhos para minimização dos problemas que os humanos vêm enfrentando.[...] É a natureza humana que deve merecer atenção nos estudos de comunicação e cultura organizacional. (FREITAS, 2006, p. 61)

Na visão de Balmer e Dinnie (1999, p. 184), quando duas empresas se unem, elas criam, na verdade, uma nova identidade corporativa, que deve ser cultivada para permitir que os diversos stakeholders se identifiquem com a nova organização. A identidade corporativa, juntamente com a comunicação organizacional podem ser vistas, por metáfora, como o fornecimento de espelhos e janelas, pois refletem e revelam a cultura e a personalidade da organização. De acordo com os autores, o processo de gerenciamento de uma fusão é particularmente complicado, pois implica o fim de duas empresas, para criação de uma nova, cujo futuro, na melhor das hipóteses, é incerto. E observam que é responsabilidade da alta gestão responder às múltiplas preocupações dos stakeholders internos e externos de ambas as empresas, durante todas as fases do processo de fusão.

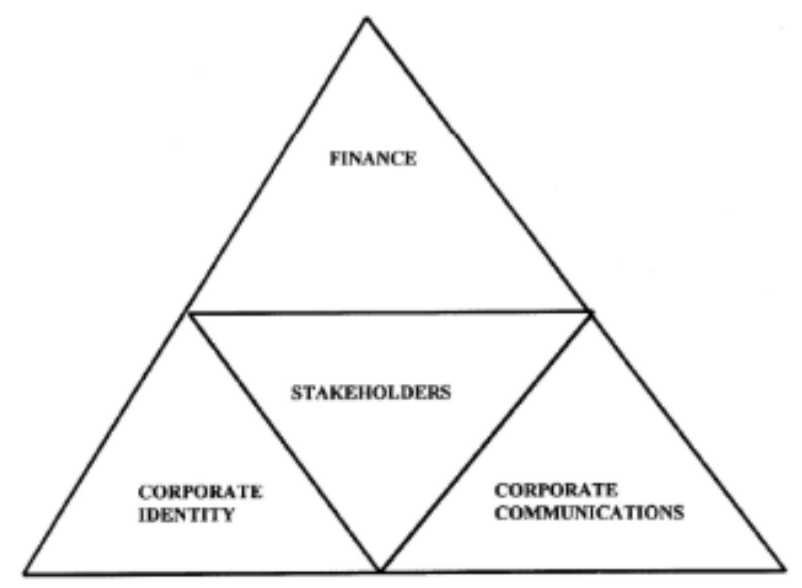

Quadro 4 - Merger Mix (BALMER; DINNIE, 1999) 
Para Balmer e Dinnie (1999, p. 189) implementação bem sucedida de uma fusão seria consequência da interação de quatro elementos: identidade corporativa, comunicação corporativa e finanças, com o respaldo do relacionamento com grupos de stakeholders das duas organizações oriundas, que devem ser considerados de crucial importância para os processos combinatórios.

\subsection{Reputação: conceitos, interfaces e mensuração}

Como bem definiu o filósofo grego Sócrates há mais de dois mil anos, a maneira de se conseguir boa reputação reside no esforço em ser aquilo que se deseja parecer. Ou seja, a reputação deve vir como o reflexo de um espelho virtual e não um cenário fictício de uma fotografia perfeita, onde as organizações gostariam de estar.

Para compreender a reputação como base comparativa deste estudo, é necessário repassar os conceitos de identidade corporativa e imagem, considerando o entendimento de Almeida (2005, p. 78), de que a reputação se constitui nas interpretações e consolidação das identidades e imagens e estas por sua vez, se retroalimentam da reputação. Para Fombrun e Van Riel, identidade corporativa consiste em

[...] (a) características que os funcionários consideram central para a empresa, (b) características que fazem a empresa distinta de outras empresas (aos olhos de funcionários) e (c) as características que permanecem, ligando presente e passado ao futuro. (FOMBRUN; VAN RIEL, 2004)

Já na visão de Baldissera, a identidade organizacional se renova constantemente, à medida que a organização se relaciona dialogicamente com seus públicos. E o autor destaca a complexidade de eventuais negociações:

[...] a forma assumida pela identidade organizacional é permanentemente atualizada nas complexas negociações realizadas nas fronteiras culturais, ou seja, nos lugares em que a identidade cultural (organização) relaciona- se dialogicamente com os "outros", sejam as identidades que estão fora dela e/ou as muitas vozes identitárias internas. Essas fronteiras culturais são pensadas como flui- das, dinâmicas, diluídas, mas que, em determinados momentos, nos processos de transação, podem apresentar-se rígidas, densas, duras, quase que impenetráveis, o que, também, pode ser um 
processo de auto-preservação, sobrevivência identitária. (BALDISSERA, 2007, p. 236)

A definição de imagem, segundo lasbeck (2007, p. 88), corresponde à configuração mental e sobretudo afetiva que o receptor elabora com base na relação do discurso que recebe e suas próprias idiossincrasias, experiências anteriores, visões de mundo, desejos e necessidades. Para Barnett, Jermier e Lafferty (2006), a transição da identidade corporativa para a imagem é uma função de relações públicas e marketing, que tentam moldar a impressão que as pessoas têm da organização. Segundo eles, a imagem pode ser formada, mas não controlada pela organização, porque fatores como cobertura da mídia, regulamentações governamentais e a dinâmica do mercado também influenciam as impressões sobre a empresa.

Com base nestas interpretações, pode-se descrever identidade corporativa como as características que definem e diferenciam uma empresa perante seus públicos, ou seja, sua personalidade. Já a imagem provem das percepções dos stakeholders sobre a comunicação de massa, relações interpessoais e a própria experiência individual. Em resumo, a imagem corporativa seria uma fotografia multifacetada do que a empresa é, o que a empresa faz e o que a empresa diz.

Segundo Barnett, Jermier e Lafferty (2006), por falta de consenso entre os pesquisadores, a reputação pode ser analisada sob três aspectos distintos: como um estado de consciência, como avaliação e como um ativo. O primeiro olhar, de reputação como consciência, refere-se ao termo utilizado para indicar que os stakeholders tem uma consciência geral sobre determinada empresa, mas sem fazer julgamentos sobre tal. O termo mais adequado para definição de reputação corporativa neste enfoque seria percepção. Para o segundo grupo, de reputação como avaliação, os stakeholders são envolvidos em uma avaliação do status da entidade e incluem referências à reputação corporativa como julgamento, estimativa, avaliação ou medição. Este grupo também inclui referências a respeito, estima pela empresa e quão atrativa a empresa é. Os termos 'opiniões' e 'crenças' se encaixam nesse grupo. O terceiro grupo, rotulado como ativo, incorpora as definições de reputação como algo de valor e significado para a empresa, incluindo referências como um recurso ou como um ativo intangível, financeiro ou econômico. Dentre as 
três possibilidades apresentadas, os autores declaram inclinação para o entendimento de reputação corporativa como avaliação. Ou seja, julgamentos coletivos dos observadores de uma organização, com base nas avaliações dos impactos financeiros, sociais e ambientais atribuídos à empresa ao longo do tempo.

Tanto na concepção de Barnett, Jermier e Lafferty ou como bem econômico, como define Fombrun (2007, p. 75), o que se pode concluir é que a reputação precisa ser tratada como um recurso estratégico da organização, que deve ser gerenciado por meio de ações estruturadas de comunicação. Charles Fombrun e Cees Van Riel, reconhecidos internacionalmente, além da atuação acadêmica, por serem os fundadores do Reputation Institute, fundado em 1997 e presente em mais de 25 países visando à geração de conhecimento e pesquisa da reputação nas organizações, afirmam que existem cinco dimensões da comunicação nas organizações: visibilidade, transparência, distintividade, consistência e autenticidade. As organizações que melhor atuam nestas dimensões, obtêm as melhores posições em reputação. $O$ instituto desenvolveu o modelo de pesquisa RepTrack®, metodologia de análise e avaliação de reputação das organizações com base em sete pilares de análise: produtos e serviços; inovação; liderança; cidadania; desempenho financeiro; governança; e ambiente de trabalho. Cada fator interfere na percepção dos stakeholders em relação à admiração, respeito e confiança.

De acordo com Fombrun (2007, p. 76), um sistema efetivo de gestão da reputação deve estar apoiado em dois alicerces: minimização dos riscos de danos e maximização dos ganhos com as oportunidades. Este processo de antecipação de potenciais riscos, aliado a uma equilibrada e relativizada determinação de peso reputacional de influência, proporciona às organizações um colchão de proteção reputacional, que amortece e as prepara para os inevitáveis e nem sempre previsíveis impactos negativos. Segundo o autor, entender o que as partes interessadas querem da empresa é fundamental para a criação de confiança, admiração, estima e sentimento positivo. Com isso, a organização parte para um patamar mais elevado, de construção de capital reputacional, que passa pelo diálogo, escuta e compreensão de seus stakeholders. 
Outro aspecto importante a se considerar é que a reputação é construída sob a lógica de cada contexto social em que a organização está inserida. Com isso, as organizações da atualidade pós-revolução tecnológica convivem com a exposição automática, inadvertida, em tempo real e em escala global imposta pela sociedade contemporânea e são impelidas um óbvio, mas nem sempre praticado alinhamento ético, de manter a coerência entre os valores professados e suas práticas (ROSA, 2007, p. 67). A reputação corporativa, construída lenta e gradualmente por décadas, torna-se a cada dia mais vulnerável e sujeita a variáveis externas que podem destruí-la em questão de dias ou horas com o auxílio das novas tecnologias digitais de informação e comunicação. Surge, hoje, como grande desafio para as relações públicas, a compreensão do novo ecossistema digital com seus dispositivos midiáticos, para, a partir deste entendimento, prever danos à reputação e desenvolver o planejamento estratégico da comunicação da organização, fundamentado por seus valores éticos. Neste sentido, lasbeck (2007, p. 92) nos impele ao questionamento sobre o papel da opinião pública na formação da reputação das organizações.

Conforme apresenta Almeida (2009, p. 234), a gestão eficaz da reputação corporativa deve contemplar: a percepção dos stakeholders externos, o alinhamento dos funcionários à estratégia organizacional, a cobertura da mídia e as mensagens corporativas produzidas e veiculadas em seu processo comunicacional. Os quatro aspectos organizacionais perpassam as estratégias comunicacionais das relações públicas, seja no relacionamento com públicos externos, internos ou imprensa.

As organizações que resguardam sua boa reputação não apenas se tornam reconhecidas como tal, mas obtêm amplas vantagens competitivas. De acordo com Rosa (2007, p. 68), pesquisas apontam que empresas éticas que prezam por sua reputação possuem ganhos em cinco "cês": compram, cobram, contratam, competem e custam melhor que seus concorrentes.

Com isso, depreende-se que a gestão da reputação vai além do cumprimento das exigências legais da organização em sua atuação na sociedade, bem como não se limita à capacidade produtiva ou de geração de lucro. Faz-se necessário um comportamento permanente de diálogo, transparência e construção compartilhada 
de valores com seus públicos prioritários, capaz de cultivar e fortalecer o relacionamento entre empresa e sociedade, somente possível nos ambientes em que as relações públicas se inserem como parte estrutural das organizações. 


\section{RELAÇÕES PÚBLICAS EM PROCESSOS DE FUSÕES: ESTUDO DE CASOS MÚLTIPLOS}

\subsection{Objeto da pesquisa}

Quais são os vínculos entre o trabalho estratégico de relações públicas e o sucesso dos processos de fusões nas grandes organizações? Este trabalho tem como objetivo central a busca estruturada desta questão e suas razões, a partir do estudo de organizações resultantes de processos de fusões que utilizam o trabalho estratégico de relações públicas, pautado por processos comunicacionais estruturados em diálogo e transparência que proporcionem a construção de relacionamentos com seus públicos e consequentemente a valoração de seu ativo reputacional.

Dentre os objetivos específicos a serem alcançados, destacam-se o estudo do impacto da comunicação como estratégia na reconstrução e gerenciamento do relacionamento com seus públicos de interesse; identificação de processos comunicacionais estruturados que não se restrinjam apenas às perspectivas funcionalistas e instrumentais; e identificação da correlação entre os processos comunicacionais analisados e a construção de novas identidades e culturas organizacionais.

A partir da análise de organizações de renomado destaque reputacional resultantes de processos de fusões, os pressupostos teóricos estabelecidos neste estudo foram que:

- O processo comunicacional estratégico contribui fortemente para a reconstrução do relacionamento com seus públicos;

- As combinações empresariais pautadas por estes processos favorecem o estabelecimento de novas culturas organizacionais;

- A comunicação estratégica atua como facilitadora nos processos de mudanças que impactam os públicos da nova organização;

- O papel das relações públicas é reconhecido e valorizado como estratégico pela alta gestão destas organizações; 
- Como consequência e entrelaçamento dos pressupostos anteriores, o trabalho estruturado de relações públicas impacta diretamente no sucesso dos processos de fusões das organizações.

\subsection{Metodologia de análise}

Para dar início ao desafio de desvendar o conhecimento científico, se faz necessária a renúncia à "tentação da certeza", como alertam Maturana e Varela (2003). A realidade torna-se interpretável de acordo com a compreensão das pessoas sobre determinado tema. $\mathrm{E}$ para que possamos conduzir a análise à luz do conhecimento científico e verificável, a escolha da metodologia adequada torna-se fator de suma importância. De acordo com Jorge Duarte,

[...] ao retratar a realidade de forma completa e profunda, o pesquisador destaca a multiplicidade de dimensões presentes em uma determinada situação, enfatizando a sua complexidade natural e revelando as possíveis inter-relações de seus componentes. (DUARTE, 2012)

Para contribuir com a teoria ainda não consolidada, a pesquisa foi dividida entre revisão bibliográfica, com a organização e compilação do material teórico existente, apresentado nos capítulos anteriores, e pesquisa qualitativa com estudo de casos múltiplos, a partir de evidências de duas fontes: entrevistas, meio pelo qual foram exploradas as percepções dos executivos da área de comunicação institucional e interna das organizações pré-estabelecidas, e análise de documentação.

A escolha desta abordagem metodológica explica-se pela necessidade de se obter conhecimento sobre o tema estudado, permitindo uma complexa inter-relação de termos, conceitos e hipóteses, além da necessidade advinda dos objetivos em responder às questões "como" e "porque" em eventos contemporâneos, conforme estabelece Yin (2010, p. 29). Para Lopes e Penafieri (2011, p. 289), a pesquisa qualitativa se justifica "quando há necessidade de uma investigação aprofundada, quando o objeto a ser pesquisado é pouco conhecido. O seu objetivo central é identificar características de um fenômeno e não mensurá-las". A idéia maior deste trabalho é antes contribuir para o entendimento de um tema recorrente na sociedade 
atual, porém pouco analisado do ponto de vista acadêmico e científico, por meio da análise de fatos e detalhes dos casos existentes.

\subsection{Estrutura da pesquisa, protocolo e proposta de dados}

O ponto de partida para o protocolo de seleção (ver quadro 5) surgiu da compilação das organizações listadas no Relatório de Fusões e Aquisições no Brasil da consultoria PWC no período de 2008 a 2012 e no Boletim de Fusões e Aquisições da Associação Brasileira das Entidades dos Mercados Financeiro e de Capitais (ANBIMA), no mesmo período e apontou 380 processos de fusões, aquisições e parcerias, dentre os diversos formatos de combinações empresariais possíveis. A escolha do período recortado (de 2008 a 2012) para o estudo foi proposta para que os casos analisados tivessem, no mínimo, dois anos de existência, tempo médio para a conclusão dos processos de integração, segundo Barros (2003, p. 37).

De acordo com Marks e Mirvis (2010, p. 12), as combinações empresariais evoluem proporcionalmente ao aumento do nível de investimento, controle, impacto e dificuldade, conforme apresentado no capítulo dois, sobre fusões. Em que pese a colocação dos autores sobre a aquisição como o extremo de complexidade nos processos de integração, para fins da pesquisa houve uma seleção intencional exclusiva das combinações que se encaixam na classificação de fusões.

Do ponto de vista comunicacional, a construção de uma identidade organizacional inédita, fruto da combinação de duas ou mais empresas que deixam de existir diante da formação de uma terceira empresa nova, como Barros (2003, p. 19) define fusão, representa um cenário mais fértil para a análise de reconstrução de relacionamentos, reputação e cultura, objetos de estudo desta pesquisa.

Outro aspecto a ser considerado foi a amplitude de contextos e variações de níveis de transações dentre as classificadas como aquisições, desde a concepção total deste conceito, até transações que já vinham se desdobrando para este cenário por aquisições de participações recorrentes e finalmente uma transação final. Principalmente por meio da crescente participação dos fundos de pensão no patrimônio empresarial brasileiro (ROSSETTI, 2001), que representa uma intensa 
intervenção econômica, mas não necessariamente cultural ou reputacional. Com isso, os níveis de impacto e integração seriam demasiado amplos para assegurar uma análise estatística.

Com isso, os 380 processos de fusões e aquisições listados inicialmente deram lugar a quinze casos de fusões. Na sequência, foi efetuada a análise cruzada das organizações resultantes de fusões no período de 2008 a 2012, com os principais ranking nacionais e internacionais de destaque reputacional (Empresas mais admiradas do Brasil, da revista Carta Capital; Dow Jones Sustainability Index; Melhores empresas para se trabalhar, das revistas Exame e Você SA; Guia Exame de Sustentabilidade, da Editora Abril; Prêmio Aberje e Índice de Sustentabilidade Empresarial (ISE) da BMF\&Bovespa. Duas das novas empresas deixaram de existir e das treze restantes, seis não obtiveram citação em nenhum dos ranking reputacionais.

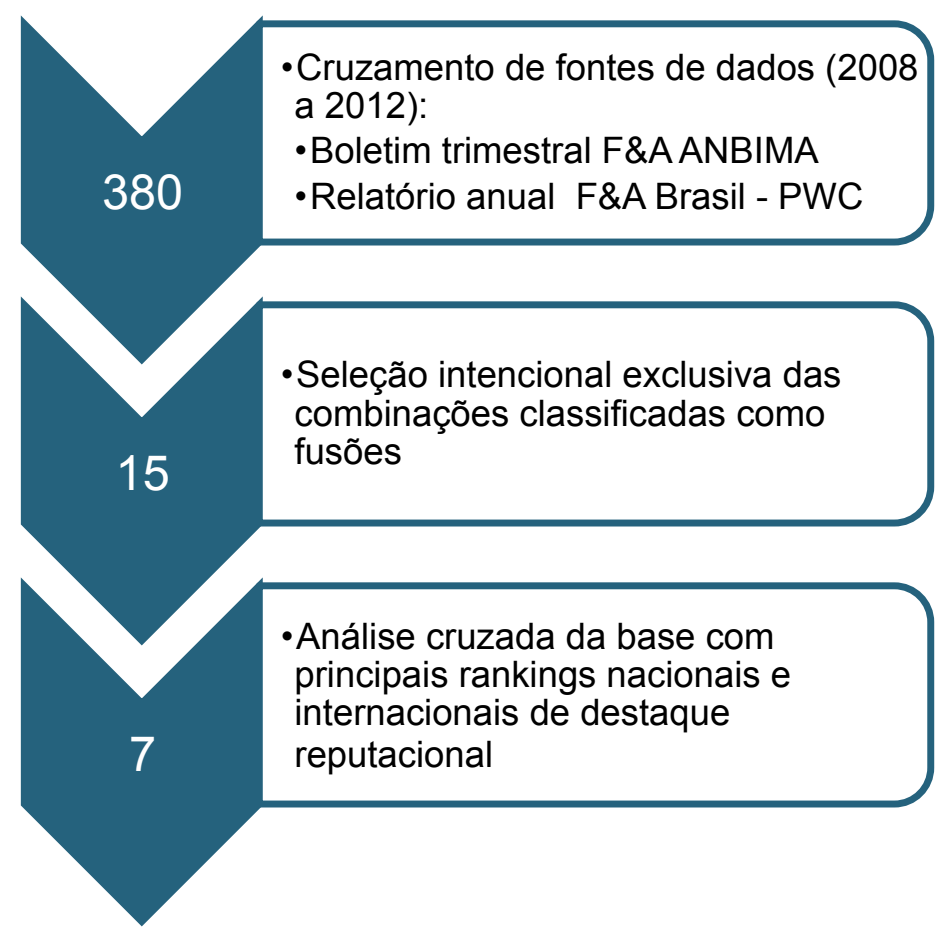

Justificativa: 2 anos é o tempo médio para conclusāo dos processos de integração (Barros, 2003)

\section{Justificativas:}

1.Cenário mais fértil para reconstruçāo de relacionamentos, reputação e cultura.

2.Amplitude de contextos e variaçōes de niveis de aquisiçōes.

Dow Jones Sustainability İndex;

2. Empresas mais admiradas do Brasil Carta Capital;

3. Guia Exame de Sustentabilidade Abril;

4. Îndice de Sustentabilidade Empresarial (ISE) - BMF\& Bovespa;

5. Melhores empresas para trabalhar Exame e Você SA

6. Prêmio ABERJE

Quadro 5 - Protocolo de seleção da amostra. Elaborado pela autora

Portanto, a amostra para aplicação do estudo de casos condensou-se em sete organizações resultantes de processos de fusões no cenário brasileiro entre os anos de 2008 e 2012, conforme apresentado no Quadro 6. Ao serem convidadas para o 
estudo, duas organizações decidiram não participar, alegando troca das equipes responsáveis pela condução do processo; outras duas organizações não se pronunciaram, após vários contatos via telefone e e-mail; por fim, três aceitaram participar da pesquisa. Uma vez que a definição da amostra partiu de minucioso protocolo de seleção, não haveria sentido em uma eventual substituição das organizações não participantes. Além deste fator, foi considerado o apontamento da banca de qualificação realizada em setembro de 2014, que sugeriu a redução da amostra inicial, devido ao aprofundamento da análise que o estudo se propõe.

\begin{tabular}{|llll|} 
Empresa & Organizações de origem & $\begin{array}{l}\text { Ano da } \\
\text { Fusão }\end{array}$ & $\begin{array}{l}\text { Convite para } \\
\text { Pesquisa }\end{array}$ \\
\hline BRF & Sadia e Perdigão & 2009 & Aceito \\
\hline Itaú Unibanco & Itaú e Unibanco & 2008 & Aceito \\
\hline LATAM Airlines & TAM e LAN & 2010 & Aceito \\
\hline BM\&F Bovespa & Bovespa Holding e BM\&F & 2008 & Recusa \\
\hline Fibria & Aracruz e VCP & 2009 & Recusa \\
\hline Raia Drogasil & Drogasil e Raia & 2011 & Não respondido \\
\hline Via Varejo & $\begin{array}{l}\text { Grupo Pão de Açúcar e } \\
\text { Casas Bahia }\end{array}$ & 2009 & Não respondido \\
\hline
\end{tabular}

Quadro 6 - Composição da amostra do estudo de casos múltiplos. Elaborado pela autora

Como instrumento de coleta de dados, foram realizadas entrevistas individuais com os executivos responsáveis pelo desenvolvimento e condução dos planos de comunicação institucional e interna das três organizações acima mencionadas, com apoio de roteiro semiestruturado; bem como o levantamento de documentação da empresa, por meio de seus canais de comunicação interna e institucional, relatórios anuais e de sustentabilidade, manuais, matérias noticiadas pela imprensa sobre as organizações e citações em estudos acadêmicos. De acordo com Yin (2010, p. 125), a coleta de dados para estudos de casos devem buscar evidência confirmatória, com base em evidência de duas ou mais diferentes fontes. As informações coletadas e analisadas vêm a seguir. 
As entrevistas foram realizadas com:

1. Valerie Cardier Adem, superintendente de Endomarketing do Itaú Unibanco, entrevista presencial em 03 de novembro de 2014;

2. Paulo Marinho, superintendente de Comunicação Corporativa do Itaú Unibanco, entrevista presencial em 10 de novembro de 2014;

3. Marcos Caetano, atual diretor global de comunicação corporativa da BRF e então diretor de marketing, recursos humanos e sustentabilidade do Unibanco na época da fusão Itaú Unibanco, entrevista presencial em 19 de novembro de 2014.

4. Adriana Vera e Silva, gerente de relações institucionais e governamentais da Latam, entrevista presencial em 21 de novembro de 2014.

\section{Roteiro semiestruturado para entrevistas com executivos das organizações}

1. Histórico da organização, resgate das organizações que deram origem e seus fundadores;

2. Razões para o processo de fusão;

3. Organograma e reporte da área (pré e pós-fusão);

4. Planos de comunicação institucional e interna para o processo de fusão:
a. Detalhamento dos planos por público;
b. Principal motivação para elaboração do plano;
C. Momento em que foram elaborados;
d. Grau de envolvimento da alta administração;
e. Participação das áreas de cada uma das empresas;
f. Nível de abertura para diálogo com os públicos;
g. Mensuração de resultados em relações públicas;
h. Principais desafios da comunicação no processo;

5. De que modo a percepção dos stakeholders impactou processo de integração (feedback);

6. Princípios organizacionais pré e pós-fusão;

7. Relacionamento da organização com stakeholders pré e pós-fusão;

8. Como se deu a integração da área de comunicação/relações públicas;

9. Pesquisa de clima pré, durante e pós-fusão; 
10. Políticas de Recursos Humanos pré e pós-fusão;

11. Rituais organizacionais pré e pós-fusão;

12. Estilo de poder pré e pós-fusão;

13. Reconhecimentos obtidos pré e pós-fusão.

\subsection{Resultados da Pesquisa}

\begin{tabular}{|c|c|c|c|c|c|}
\hline \multicolumn{2}{|c|}{2008} & 2009 & 2010 & 2011 & 2012 \\
\hline BRF & & $\begin{array}{c}\text { Mai: } \\
\text { Anúncio }\end{array}$ & & $\begin{array}{c}\text { Jul: } \\
\text { Aprovação } \\
\text { CADE } \\
\text { Oficialização }\end{array}$ & \\
\hline $\begin{array}{l}\text { Itaú } \\
\text { Unibanco }\end{array}$ & $\begin{array}{l}\text { Nov: } \\
\text { Anúncio }\end{array}$ & $\begin{array}{c}\text { Fev: } \\
\text { Aprov. } \\
\text { BACEN } \\
\text { Oficialização }\end{array}$ & $\begin{array}{l}\text { Ago: } \\
\text { Aprov. } \\
\text { CADE }\end{array}$ & & \\
\hline LATAM & & & $\begin{array}{c}\text { Ago: } \\
\text { Anúncio }\end{array}$ & $\begin{array}{c}\text { Set: } \\
\text { Aprov. Chile } \\
\text { Dez: } \\
\text { Aprov. Brasil }\end{array}$ & $\begin{array}{c}\text { Jun: } \\
\text { Aprov. EUA } \\
\text { Oficialização }\end{array}$ \\
\hline
\end{tabular}

Quadro 7 - Linhas do tempo das fusões estudadas. Elaborado pela autora

\begin{tabular}{|cccc|}
\hline BRF & $\begin{array}{c}\text { Alteração na } \\
\text { razão social }\end{array}$ & $\begin{array}{c}\text { Alteração } \\
\text { de marca } \\
\text { Marcas mantidas } \\
\text { como linhas de } \\
\text { produtos }\end{array}$ & $\begin{array}{c}\text { Site BRF: institucional } \\
\text { Sites Sadia e Perdigão: } \\
\text { comercial }\end{array}$ \\
\hline Itaú Unibanco nome & $\begin{array}{c}\text { Sim, junção de } \\
\text { ambas }\end{array}$ & Sim, Itaú & Site único \\
\hline LATAM & $\begin{array}{c}\text { Sim, junção de } \\
\text { ambas }\end{array}$ & $\begin{array}{c}\text { Não, previsão de } \\
\text { marca única para } \\
2015\end{array}$ & $\begin{array}{c}\text { Site LATAM: } \\
\text { institucional } \\
\text { Sites TAM e LAN: } \\
\text { comercial + institucional }\end{array}$ \\
\hline
\end{tabular}

Quadro 8 - Análise comparativa dos perfis das organizações. Elaborado pela autora

\section{Caso 1: BRF (fusão entre Sadia e Perdigão)}

Concorrentes diretas há mais de 60 anos, Sadia e Perdigão possuíam em 2009 diversas características em comum: ambas fundadas no oeste do estado de Santa Catarina, fabricantes de produtos que disputavam entre si a preferência do 
consumidor, exportadoras de alimentos e ainda que não tivessem conhecimentos profundos da cultura alheia, ambas possuíam estruturas hierárquicas conservadoras. Em três ocasiões distintas, as duas empresas demonstraram interesse em algum tipo de combinação: em 1999, surgiram as primeiras conversas entre os acionistas, sem sucesso. Em 2002, foi criada a Brazilian Foods (BRF), uma parceria que visava somente a exportação em conjunto para uma região específica do mundo e que foi cancelada um ano e meio após o início da operação. A terceira, em 2006, foi uma tentativa mal sucedida da Sadia para adquirir a Perdigão de forma hostil, ao tentar obter o controle por meio da compra de ações, sem negociar com os então controladores e executivos. No período entre a malfadada proposição e a efetivação da união, Sadia passou por sérios problemas financeiros e viu seu valor de mercado cair de $\mathrm{R} \$ 8,5$ bilhões em 2008 para $\mathrm{R} \$ 2,7$ bilhões em 2009. (DALLA COSTA; SOUZA-SANTOS, 2009; MEYER; COSTA, 2009; SEREIA; CAMARA; VIEIRA, 2011)

Em maio de 2009, é anunciado acordo de associação com participação de 32\% para a Sadia e $68 \%$ para a Perdigão, que resulta na criação da BRF Brasil Foods S.A., uma das principais companhias alimentícias do país e do mundo, maior exportadora mundial de aves e maior empresa global de proteínas. A nova organização nasce com mais de cem mil funcionários e um sentimento mútuo de rivalidade, que permeava todos os seus níveis hierárquicos. Em mais um fator complicador, a integração das estruturas começou a ser trabalhada antes da aprovação oficial do Conselho Administrativo de Defesa Econômica (CADE) e teve que ser interrompida, gerando impasse neste que é notoriamente um dos momentos mais delicados do processo. Como ambas as empresas compartilhavam liderança de mercado em varias linhas de produtos, o processo de avaliação e aprovação pelo órgão regulador levou cerca de dois anos para ser autorizado e previa uma série de restrições, de modo a garantir equilíbrio para a concorrência, conforme apresenta o quadro 9.

Com isso, o processo de comunicação teve que se restringir à nova marca da organização, o que reforçava o distanciamento e a rivalidade existentes no âmbito interno. Externamente, as mensagens chegavam confusas aos públicos, pois as marcas Sadia e Perdigão, que permanecem ativas para as linhas de produtos, continuavam a disputar espaço pelo mesmo nicho de clientes, os sites Sadia e 
Perdigão existiam em paralelo, com mínima referência à antiga concorrente e agora "irmã", e os comunicados à imprensa da BRF restringiam-se às divulgações financeiras. Mesmo após a aprovação do CADE, a comunicação refletia o espírito da organização: apesar do mesmo sobrenome, as duas marcas não se somavam e não se misturavam. Equipes de vendas continuavam a atuar em separado e, para piorar, disputas internas entre antigos controladores acirravam o clima de animosidade. 


\begin{tabular}{|c|c|c|c|}
\hline \multirow{3}{*}{ PRODUTO } & \multicolumn{3}{|c|}{$\begin{array}{l}\text { Perdigão } \\
\text { Produtos da marca Perdigão que terão venda suspensa no Brasil }\end{array}$} \\
\hline & & PRAZO DE SUSPENSÃO DE VENDA & \\
\hline & 3 anos & IANO & 4ANOS 5ANOS \\
\hline Presunto & & 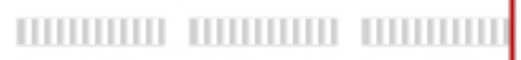 & 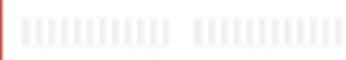 \\
\hline Tender & & 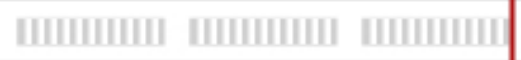 & 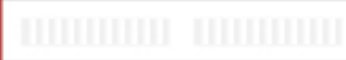 \\
\hline Linguiça & & 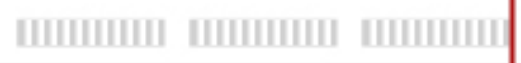 & 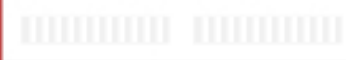 \\
\hline Paio & & 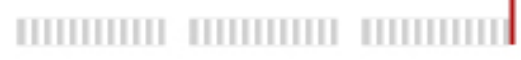 & 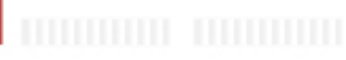 \\
\hline Salames & 4 anos & 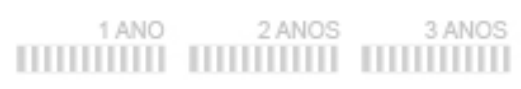 & IIIIIIIIII) \\
\hline Lasanha & 5 anos & 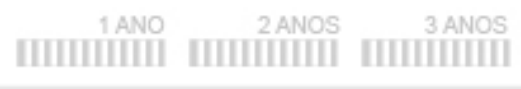 & 4ANOS 5ANOS \\
\hline Pizzas & & 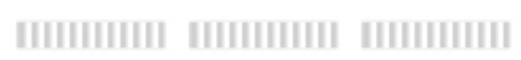 & 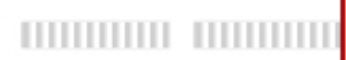 \\
\hline Kibes e almôndegas & & ІІІІІІІІ & 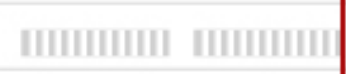 \\
\hline Frios saudáveis & & 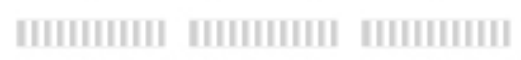 & 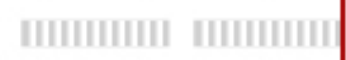 \\
\hline
\end{tabular}

\section{abatavo}

Batavo

Produtos da marca Batavo que terão venda suspensa no Brasil

Derivados de carnes processadas, incluindo hambúrguer, salsicha, mortadela, peru in natura,

kit festa aves e empanados, além

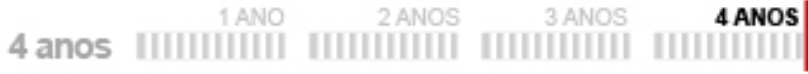
de margarina

\section{BRF BRF \\ Instalações que a BRF terá que vender}

Cadeias completas de produção:

- 10 fábricas de alimentos processados

- 2 Abatedouros de suínos

- 2 Abatedouros de aves

- 4 Fábricas de ração

- 12 Granjas de matrizes de frangos

- 2 Incubatórios de aves

- 8 Centros de Distribuição
Alienações equivalem a

$\mathbf{8 0} \%$ da produção da

Perdigão voltada ao

mercado brasileiro

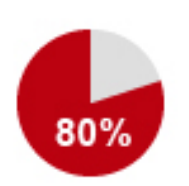

\section{Marcas chamadas 'de combate' que BRF aceitou vender}

- Rezende - Patitas - Texas

-Wilson · · Tekitos • Escolha Saudável Fiesta

- Freski
- Confiança

- Doriana

- Delicata

Quadro 9 - Restrições impostas pelo CADE para aprovação da fusão entre Sadia e Perdigão.

Fonte: site G1 (http://g1.globo.com/economia/negocios/noticia/2011/07/brf-e-cade-selam-acordo-efusao-sadia-e-perdigao-e-aprovada.html) 
Em abril de 2013, o empresário Abílio Diniz assumiu a presidência do Conselho de Administração da BRF, em substituição a Nildemar Secches, antigo controlador da Perdigão, a pedido dos fundos de investimentos Tarpon e Previ, principais acionistas da nova organização. Sua chegada representou o momento de virada, ainda que tardia, tanto nos aspectos estruturais da fusão, de integração efetiva de equipes e das estratégias do negócio, como do ponto de vista comunicacional. Passados quatro anos do anúncio e cerca de dois anos após a aprovação legal, Abílio Diniz estabeleceu metas de cem dias, estratégia usual dos especialistas em fusões, em sua fase inicial. (LANDIM, 2013)

Desde 2011 estava aprovado e até 2013, final do ano, nada havia acontecido de muito efetivo. [...] Criamos uma marca bonita, um bom símbolo. Mas aquilo não dizia nada, não estava construindo uma nova empresa ali. É simplesmente a marca de uma empresa fragmentada. (MARCOS CAETANO)

A comparação das informações de 2009 - anúncio da fusão, com o Relatório Anual mais recente - de 2014, (ver quadro 10) aponta, no intervalo de cinco anos, um enxugamento considerável no total de funcionários, na quantidade de unidades fabris e no numero de seus produtos. Estas reduções justificam-se, em parte, pelas restrições impostas pelo CADE, que condicionou a aprovação da fusão à venda de determinadas linhas de produtos. Para atender às exigências do órgão regulador, a BRF descontinuou grande parte de sua produção de lácteos. Além disso, recentemente a empresa implantou um projeto de redução de $35 \%$ na quantidade de produtos em seu portfólio no Brasil, visando simplificação de processos e busca por melhores índices de eficiência. Em contrapartida, neste mesmo período, o número de fábricas no exterior mais do que triplicou, de três para dez unidades, em consonância com a proposta da fusão de internacionalização. O comparativo dos dados financeiros, como valor de exportações anuais, receita líquida e valor de mercado, reafirma as conjecturas promissoras da organização e, por assim dizer, o alcance de seus objetivos estratégicos para a fusão: crescimento e expansão internacional. 


\begin{tabular}{|lcc|}
\hline Funcionários & 2009 & 2014 \\
\hline Parque industrial & 129 mil & 104 mil \\
\hline Países atendidos & $\begin{array}{c}63 \text { unidades } \\
(3 \text { no exterior })\end{array}$ & $\begin{array}{c}57 \text { unidades } \\
(10 \text { no exterior })\end{array}$ \\
\hline Produtos no portfólio & 110 & 120 \\
\hline Exportações anuais & $\mathrm{R} \$ 9,1$ bilhões & $\mathrm{R} \$ 13,6$ bilhões \\
\hline Receita líquida & $\mathrm{R} \$ 15,9$ bilhões & $\mathrm{R} \$ 29$ bilhões \\
\hline Valor de mercado & $\mathrm{R} \$ 19,7$ bilhões & $\mathrm{R} \$ 55,3$ bilhões \\
\hline
\end{tabular}

Quadro 10 - Comparativo de indicadores da BRF de 2009 e 2014. Elaborado pela autora Fontes: Relatórios Anuais BRF.

\section{Caso 2: Itaú Unibanco}

Em 03 de novembro de 2008 foi anunciada a fusão dos bancos brasileiros Itaú e Unibanco, respectivamente segunda e quarta maiores instituições financeiras do país. A transação, elaborada em sigilo absoluto durante 15 meses por seus presidentes e acionistas majoritários, Roberto Setubal e Pedro Moreira Salles, resultou no surgimento do maior banco privado do hemisfério sul e um dos maiores do mundo, em valor de mercado. Em meio a um cenário de forte instabilidade econômica mundial, a nova empresa nasceu com cerca de 14 milhões de clientes de conta corrente, quase 5.000 pontos de atendimento e pouco mais de 100 mil funcionários. (ITAÚ UNIBANCO; G1, 2008; NAPOLITANO; MANO, 2008)

De acordo com Marcos Caetano, então diretor de marketing, recursos humanos e sustentabilidade do Unibanco na época da fusão:

O casamento do Itaú Unibanco foi um casamento por amor, se é que existe amor no mundo empresarial. Mas o que eu quero dizer é que tanto o Pedro (Moreira Salles) quanto o Roberto (Setubal) queriam muito a fusão. Era importante naquele momento para se defender da crise mundial, para fazer um banco maior. Então a fusão foi muito boa para todo mundo. Teve todo o desgaste que tem num processo de fusão, mas lá em cima eles não iriam brigar. Isso ajudava muito. 
Alicerçado pela disposição dos controladores em concordarem entre si e na experiência das duas histórias permeadas por fusões e aquisições, o processo de integração das estruturas começou no mesmo mês do anúncio da fusão, com a formação de dezenove frentes de trabalho, sendo que a comunicação era uma delas, e foi considerado um dos mais ágeis e efetivos que se conhece no mercado, com velocidade maior que a média internacional, segundo especialistas em fusões bancárias (NAPOLITANO e SALGADO, 2009). Esta agilidade de decisão da alta cúpula impactou profundamente o processo de comunicação e relacionamento com os funcionários, segundo Valerie Adem, superintendente de Endomarketing do Itaú Unibanco:

Eu acho que o que teve de mais bem sucedido no processo da fusão
e mais especificamente de comunicação interna é que tudo foi muito
rápido e organizado. [...] E o fato de na alta cúpula, na liderança, as
coisas estarem acontecendo rápido, obrigou as equipes em baixo a
também trabalharem de forma rápida, nada ficou paralisado. As
decisões foram sendo tomadas de uma forma muito rápida pela alta
liderança e aí, na verdade, o que a gente tinha que fazer era
responder a este ritmo. Então por exemplo, a gente sabia que iria ter
a aprovação do Banco Central em fevereiro, não se sabia
exatamente quando, mas que aí, de fato, era como se a gente
tivesse com a fusão sacramentada pelo órgãos reguladores. A
comunicação interna em si já estava toda pronta, dependia da hora
de apertar o send para mandar. Mas isso tudo validado pelas duas
partes, sempre de uma forma muito rápida. Por mais que as pessoas
estivessem se conhecendo e as equipes se conhecendo, eu acho
que a questão de você ter que seguir esse ritmo e atender a estas
coisas foi muito importante para que a coisa acontecesse, de fato, de
uma forma fluida.

Ao compararmos indicadores do Relatório Anual de 2008, momento da fusão, com os mesmos parâmetros de 2014, (ver quadro 11) torna-se evidente o sucesso da fusão entre Itaú e Unibanco, que demonstra ter atingido seu objetivo estratégico, divulgado tanto interna como externamente, de "criar um conglomerado com valor de mercado que o situa entre as 20 maiores instituições financeiras do mundo e a maior do Hemisfério Sul, com plena capacidade de competir com os maiores bancos no mercado global" (FATO RELEVANTE, 2008 - ANEXO B) 


Clientes 57,5 milhões 62, 6 milhões

Funcionários $\quad 108 \mathrm{mil} \quad 93.175$

Postos de Atendimento $\quad 4,6 \mathrm{mil} \quad 5.070$

Países em que atua $12 \quad 20$

Ativos $\quad \mathrm{R} \$ 632,7$ bilhões $\quad \mathrm{R} \$ 1.208$ bilhões

Lucro líquido $\quad \mathrm{R} \$ 10,6$ bilhões $\quad \mathrm{R} \$ 20,6$ bilhões

Patrimônio líquido $\quad \mathrm{R} \$ 43,7$ bilhões $\quad \mathrm{R} \$ 95,8$ bilhões

$\begin{array}{lll}\text { Valor da marca Itaú } & R \$ 10,5 \text { bilhões } & R\end{array} 21,6$ bilhões

Quadro 11 - Comparativo de indicadores do Itaú Unibanco de 2008 e 2014. Elaborado pela autora. Fontes: Relatórios Anuais Itaú Unibanco e apresentação institucional Itaú Unibanco 2014.

Passados mais de seis anos, os números apontam um crescimento em torno de $100 \%$, tanto na presença internacional como em aspectos financeiros - ativos, patrimônio líquido e valor da marca. Em contrapartida, a busca pela eficiência se mostra presente pela redução do numero de funcionários e crescimento inibido na quantidade total de clientes e dos postos de atendimentos. Pode-se deduzir que a organização hoje produz mais gastando menos, sem despender investimentos financeiros e materiais demandados nos casos de crescimento orgânico.

\section{Caso 3: LATAM Airlines (TAM e LAN)}

Os últimos vinte anos representam uma verdadeira transformação no mercado de aviação civil brasileiro. Em decorrência da melhoria no padrão de vida da população e redução de preços das passagens, o número de passageiros apresentou crescimento superior a $100 \%$ no período de 2004 a 2013, tanto nos vôos domésticos como internacionais, de acordo com a Agência Nacional de Aviação Civil (ANAC). Entretanto, em que pesem os prognósticos positivos de crescimento, segundo a Associação Internacional de Transporte Aéreo (IATA), entidade que representa 84\% das empresas aéreas do mundo, considerando a oferta ainda escassa de 
infraestrutura, aeroportos e malha aérea, trata-se de um dos setores mais impactado por interferências como flutuação do dólar, variação de preços do petróleo, oscilações no crescimento econômico, além de fatores internos do setor, como seguro, manutenção e aquisição de aeronaves. Com isso, as companhias aéreas disputam não somente a preferência dos consumidores, mas principalmente por modelos de eficiência que permitam ganhos concorrenciais fundamentais para sua perenidade.

Neste contexto, em agosto de 2010, a TAM, maior companhia aérea no Brasil, e a chilena LAN, líder no mercado de seu país, anunciaram um acordo de intenções para união, dando origem à LATAM Airlines Group. Como o negócio dependia da aprovação de diversas instituições governamentais brasileiras, chilenas e norteamericanas, por ambas as companhias possuírem voos nos Estados Unidos, apesar do anúncio, as empresas tocaram seu dia-a-dia no paralelo por pouco mais de dois anos. Até que os órgãos reguladores dessem o aval para a transação, em meados de 2012, quase nada podia ser feito tanto em termos de integração de estruturas como em termos comunicacionais. Nesta longa fase de espera coube o trabalho de divulgação de informações e preparo para as mudanças que viriam.

O processo de fusão entre TAM e LAN aponta particularidades inerentes a um processo transnacional, que surge para acompanhar a tendência mundial de consolidação em busca de competitividade, com as vantagens de uma frota similar e complementaridade de malha latino-americana: ainda que no alto escalão pudesse haver preocupação com a perda de poder e de seus cargos, em todos os demais níveis hierárquicos da empresa, este sentimento praticamente passou despercebido. Como as empresas atuam em países diferentes, com legislações, hábitos e cultura distintos, tornava-se improvável que o 'outro lado' viesse tomar o posto de alguém do Brasil ou vice-versa.

Diferentemente dos demais casos analisados, para a LATAM, a integração dos processos e dos sistemas possui relevância maior do que a união das estruturas, neste caso à distância, pelo caráter da dispersão geográfica. A integração vem sendo trabalhada lenta e gradualmente, pois envolve aspectos operacionais delicados inerentes ao setor, que impactam a segurança e continuidade do negócio. 
Atualmente, a unificação dos processos se faz presente na área de cargas, que possuía maior complementaridade de malha, nas áreas internacionais, no plano de fidelidade e em alguns sistemas internos de tecnologia.

Os próximos passos para 2015 serão a unificação dos sistemas de compras de passagens e o grande destaque: a nova marca. Apesar de a organização possuir nova razão social, ainda que pela junção dos nomes das antigas empresas, as marcas LAN e TAM permanecem em uso comercial, reforçando interna e externamente a linha divisória entre as equipes.

\begin{tabular}{|lccc|}
\hline Clientes & 2010 & 2012 & 2014 \\
\hline Funcionários & 51.7 milhões & 64,9 milhões & 67 milhões \\
\hline Aeronaves & 47 mil & 53,5 mil & 53 mil \\
\hline Destinos & 280 & 327 & 327 \\
\hline Receitas & 115 & 135 & 135 \\
operacionais & RS\$ 4.5 bi LAN 11,3 bi TAM & US\$ 9.9 bi & US\$ 12.4 bi \\
\hline Lucro líquido & ND & US\$ $10.9 \mathrm{mi}$ & - US\$ $109.8 \mathrm{mi}$ \\
\hline
\end{tabular}

Quadro 12 - Comparativo de indicadores da LATAM de 2010, 2012 e 2014. Elaborado pela autors. Fontes: Site LATAM e Relatórios Anuais LATAM.

A comparação dos dados da LATAM (ver quadro 12) em três momentos distintos: 2010 - ao anunciarem a fusão, 2012 - quando ela se iniciou de fato, e 2014 publicação oficial mais recente-, demonstra que a empresa teve um leve crescimento no decorrer do primeiro período, sem que isso represente ganho efetivo da fusão, pois a integração operacional não havia iniciado. De 2012 para cá, quando a integração começou a ser concretizada, praticamente não alterou seu patamar de estrutura, tendo apresentado oscilações nos dados financeiros. De acordo com o Relatório Anual LATAM (2014, p. 60), este cenário justifica-se pela

[...] piora no cenário macroeconômico global e aumento da concorrência de companhias que operam voos para a América do Sul e dentro da região, o que causou pressão sobre as tarifas. Somou-se a esse cenário uma queda na demanda por transporte 
aérea como consequência da depreciação de algumas moedas locais, principalmente o peso argentino. Além disso, a realização da Copa do Mundo de Futebol no Brasil impactou negativamente a demanda por passageiros de negócios e turismo, tanto em voos domésticos quanto em rotas desde e para o Brasil nos meses de junho e julho.

Considerando-se o cenário de crise do setor de aviação civil no Brasil e no mundo, seria precipitado creditar o crescimento pouco expressivo como consequência (negativa) do processo de integração. Embora a empresa ainda não esteja usufruindo das vantagens de sinergias decorrentes das fusões, visto que grande parte das operações não foi unificada até o momento, alguns tipos de benefícios já podem ser apontados, como maior poder de negociação adquirido perante seus interlocutores. Além disso, não é possível determinar o impacto da crise atual nas empresas LAN e TAM, caso elas não tivessem se unido.

\subsubsection{Históricos das organizações}

Sem que houvesse escolha intencional, a análise das histórias das seis empresas que deram origem às três organizações estudadas apontou uma característica em comum: todas elas surgiram como empresas familiares, com forte presença dos fundadores e seus descendentes nos modelos e valores estabelecidos, em alinhamento à proposta de Schein (1984) mencionada no capitulo três, para quem o entendimento de uma cultura organizacional perpassa por sua história, seus incidentes críticos e seus estilos de lideranças.

Para a BRF, o conservadorismo e modelo hierárquico tradicional, com muitas cadeias de comando, tanto da Sadia como da Perdigão, estão sendo substituídos por uma postura mais agressiva e meritocrática das lideranças. Em relação aos estilos de liderança, enquanto a Perdigão mantinha foco na área industrial, com destaque para controle dos custos e da produção, a Sadia priorizava sua área comercial, por meio de intenso trabalho do marketing.

Esse sentimento de responsabilidade de ser líder, a gente foi construir. Eu disse 'para vocês que estão muito envolvidos com o assunto, quem foi da Perdigão, quem foi da Sadia, estamos falando de empresas muito diferentes, com antagonismos graves. Para mim, que cheguei agora, são duas empresas fundadas no período da Segunda Guerra Mundial. As duas foram fundadas por imigrantes italianos tão parecidos, que os dois vieram da região do Veneto. E as 
duas ficam no oeste de Santa Catarina. Oeste de Santa Catarina para que mora em São Paulo, é a mesma coisa. Eu não sei dizer a diferença de Videira para Concórdia. Tem lá os alemães, os italianos, os colonos imigrantes, aquele pessoal trabalhador, bacana, que construiu essa empresa. Essa é a história comum de vocês dois. Fácil fazer, desde que vocês queiram.' Então você constrói quase que um conjunto. As coisas que só uma empresa tem, mas eu quero que faça parte da nova cultura. $E$ tem que tem pelo menos uma coisa das duas. (MARCOS CAETANO)

No Itaú Unibanco, a ética dos fundadores do Itaú e do Unibanco e seu interesse pela arte se fazem presentes nos projetos sociais e culturais, ainda mais consolidados após a fusão. Outra característica similar que impactou de forma indelével a nova cultura foi o amplo histórico de combinações de ambos os bancos, propiciando uma liderança com perfil heterogêneo e multicultural, menos apegada às suas diversas raízes. Neste caso, o contraste se deu pela disciplina, foco nos processos e obsessão por resultados que marcavam o Itaú, distantes da informalidade e perfil inovador, porém com poucas entregas efetivas, segundo os próprios executivos, que caracterizavam o Unibanco.

Realmente foi uma acomodação do que era o melhor para acontecer
para essa nova organização. De alguma maneira, o Itaú, que era um
banco muito mais formal, onde as pessoas se chamavam de doutor e
usavam gravatas, deixou de ser tão formal. Isso era uma coisa que o
Unibanco já tinha, mas nem tanto também. Apesar de tudo, não
deixam de ser bancos. Por exemplo, o Unibanco era informal, mas
não permitia calça jeans às sextas-feiras. É um exemplo, mas que eu
lembro que as pessoas falavam 'nossa, pode usar calça jeans na
sexta!' O Roberto (Setubal) um dia falou que não precisava usar
mais gravata. Como é que a gente mostra isso? A gente tira uma foto
dele para o editorial da revista e ele está sem gravata. Ele vai ao
encontro entre líderes e ele e o Pedro (Moreira Salles) estão sem
gravatas. Então você também dá esses exemplos no dia-a-dia. Por
outro lado, acho que o Itaú tinha uma questão de métodos e
disciplina que talvez fosse um pouco mais solta no Unibanco, que se
manteve dentro da nova organização. Foi um aporte interessante de
processos, que não tinha tão registrado no Unibanco. Então acho
que a organização hoje é muito melhor do que uma ou outra eram no
passado, sem dúvida nenhuma. (VALERIE ADEM) Já no caso da LATAM, o fato de TAM e LAN terem começado pequenas e obtido crescimento acelerado em poucos anos fez com que ambas possuíssem fortes vínculos com seus fundadores. Entretanto, enquanto a LAN era orientada por processos bem definidos, com gestão de pessoas avançada e perfil mais objetivo e 
direto, a TAM se baseava em relacionamentos, com maior tendência à gentileza e cordialidade.

A TAM tem suas origens em 1961, numa empresa de taxi aéreo. [...] É uma empresa com um histórico muito familiar, em sua raiz. É uma empresa de dono, que no início foi vinculada ao seu fundador. Da mesma maneira, a LAN tem vínculo forte com a família Cueto, a família que a conduziu e a fez crescer. E da mesma maneira, o que elas têm de histórico em comum, é que elas são empresas que começaram pequenas e cresceram muito [...] Tem o hábito brasileiro de gentileza, de proximidade que não tem nos países LAN. Muito a ver com idioma e cultura. Eles são mais diretos, então, aos poucos, a gente teve este entendimento de que somos diferentes. O pessoal de língua portuguesa aprendeu a ser um pouco mais claro. E o pessoal de língua espanhola aprendeu a ser um pouco mais gentil. Falando de um modo bem genérico. Mas isso é uma coisa que é muito dita, que o brasileiro é pouco objetivo e muito cordial. Os da LAN são mais objetivos e pouco cordiais. (ADRIANA VERA E SILVA)

\subsubsection{Princípios organizacionais}

A análise dos princípios organizacionais das novas corporações por meio da comparação com os princípios das empresas oriundas foi realizada à luz das teorias de Tanure e Cançado (2005) e Marks e Mirvis (2010, p. 13), sobre o desequilíbrio efetivo ou perceptivo dos casos de fusões.

Ao mapear os princípios organizacionais das organizações e compará-los com o que havia no passado, nota-se que os antigos princípios da Perdigão, empresa considerada pelo mercado como o lado mais 'forte' da combinação, predominam nas premissas organizacionais da BRF. Sua missão praticamente repete a versão da Perdigão, com um pequeno adendo que remete aos interesses de expansão mundial. Nenhum atributo da antiga Sadia se faz presente na missão, visão e valores da nova empresa, reforçando a percepção mais acentuada de descontinuidade para este lado. 


\section{Missão e Visão BRF}

\section{Valores BRF}

"Nossa missão é participar da vida das pessoas, oferecendo alimentos saborosos, com qualidade, inovação e a preços acessíveis, em escala mundial."

\section{Atributos Perdigão}

- Amor de dono (qualidade e excelência)

- Inconformismo positivo (inovação)

- Fome de performance

- É pra já (visão global, agilidade local)

- Fazendo juntos (espírito de equipe)

- Inspirados pelo consumidor (foco no consumidor)

- Vida saudável (respeito pelas pessoas)

(nenhum atributo Sadia)

Quadro 13 - Princípios organizacionais da BRF. Elaborado pela autora.

No Itaú Unibanco, a visão reflete uma versão condensada da visão do Itaú, permanecendo no texto todos os atributos de sua versão antiga. Se faz relevante constar que o Unibanco não possuía missão e visão, portanto não há base comparativa, neste caso. Nos valores atuais da companhia, são identificados elementos de ambos os bancos, em quantidades similares.

\section{Missão e Visão Itaú Unibanco}

Missão: não possui

Visão: "Ser o banco líder em performance sustentável e em satisfação dos clientes."

\section{Valores Itaú Unibanco}

Atributos Itaú

Atributos Unibanco

\section{Atributo de ambos}

- Todos pelo Cliente

- Paixão pela Performance

- Liderança ética e responsável

- Craques que jogam para o time

- Foco na inovação e inovação com foco

- Processos servindo pessoas

- Ágil e descomplicado

- Carteirada não vale

- Brilho nos olhos

- Sonho grande

Quadro 14 - Princípios organizacionais do Itaú Unibanco. Elaborado pela autora. 
No caso da LATAM, a visão foi totalmente reconstruída, não refletindo nenhuma das duas empresas oriundas. Apenas um atributo LAN permanece nos valores modernos da companhia, frente a inexistência de atributos da TAM.

Missão e Visão LATAM

Missão: não possui

Visão (aspiração): "Ser um dos três melhores grupos de companhias aéreas do mundo"

\section{Valores LATAM}

\section{Atributo LAN}

(nenhum atributo TAM)

Quadro 15 - Princípios organizacionais da LATAM. Elaborado pela autora.

\subsubsection{Comunicação e Relacionamento com Stakeholders}

O estudo da comunicação interna e institucional sobre os processos de fusões e da reconstrução do relacionamento das organizações com seus stakeholders internos e externos tem início com o entendimento dos níveis de envolvimento e comprometimento da alta liderança com o trabalho de relações públicas. Cada uma das três organizações se posicionou de forma distinta: na BRF, a comunicação atuou de maneira instrumental, apenas para repasse das informações necessárias, por cerca de cinco anos, acompanhando o ritmo lento e intermitente das mudanças operacionais. Somente após a drástica mudança na alta liderança, com a chegada de Abílio Diniz na presidência do Conselho de Administração, a comunicação iniciou um trabalho estratégico, com foco na criação da nova cultura organizacional.

Quando questionado sobre a correlação entre o sucesso do processo combinatório com a intervenção de comunicação, Marcos Caetano, Diretor Global de Comunicação Corporativa afirmou ter certeza que o investimento de cultura faz diferença no resultado, ainda que não consiga mensurar quantitativamente: "As empresas que deram grandes saltos, estes saltos sempre foram culturais. Que 
começa numa visão de gestão, mas em algum momento precisa ser comunicado". E complementa:

É claro que a cultura não é só a comunicação que faz. É a gestão, como é que os executivos se comportam, como eles trabalham com suas equipes, mas isso tudo é comunicação também. $E$ uma coisa que eu sempre digo, é que a (área de) comunicação, por melhor que seja, não substitui o trabalho de gestão, de um bom gestor. Comunicação é parte fundamental do trabalho do gestor. Um gestor que não se comunica é um péssimo gestor. Um CEO encastelado não existe mais. Ele tem que falar. Ele vai falar de público, ele vai circular pela empresa, ele vai mandar carta, não sei o que ele vai fazer. Na minha opinião ele tem que fazer tudo isso.

No Itaú Unibanco, a comunicação interna se declarou autônoma e 'empoderada' desde o primeiro momento da fusão. Ao passo que as decisões da alta liderança atingiam velocidade acelerada, esta agilidade permitia um posicionamento mais próativo da comunicação, que na velocidade padrão dos processos combinatórios, tende a ser cobrada por respostas. Questionada sobre o papel da comunicação interna no sucesso do processo de fusão, a entrevistada Valerie Adem aponta:

Você tem duas maneiras de falar com o colaborador nesta hora. Uma é pelo gestor e a outra é pela comunicação. A gente teve a sorte de ter muito 'empoderamento' da liderança. Tanto o Ricardo Marino, que na época era a pessoas responsável pelos recursos humanos, como depois o Zeca (Rudge), sempre teve muita abertura para a gente fazer um trabalho legal, teve orçamento, teve disponibilidade de fazer coisas diferentes. O próprio lançamento da cultura foi um lançamento diferente. [...] Depois que veio o encontro entre líderes. Tudo pensado com prioridade, para que as coisas acontecessem. A gente teve verba para construir um novo portal dentro do banco, que era um canal importante para conseguir se comunicar de forma efetiva. A gente pode construir uma TV interna nos elevadores, hoje a gente está com o painel digital também. Então eu acho que não é a comunicação interna em si. Eu acho que é ter uma liderança que acredita que esta comunicação pode fazer a diferença em um momento como este. Obviamente que a qualidade deste trabalho faz diferença também. Mas não é fazer o trabalho em si. Eu acho que é ter autonomia e 'empoderamento' e ter proximidade com as áreas parceiras. Estar próximo de recursos humanos é essencial. Ter agilidade nas respostas e nas aprovações, quando você tem que levar o assunto para cima, também é essencial. A gente teve, primeiro, a diretriz de se trabalhar com transparência, tinha autonomia, tinha recursos financeiros e agilidade da liderança, na hora de aprovar as coisas. Então acho que é uma mescla das coisas, que se traduz na comunicação interna.

Extrapolando o período de integração, a comunicação institucional se vê hoje em um patamar de fato mais estratégico, inclusive com assento no board da companhia, 
pois como consequência da fusão foi criada uma nova estratégia de negócios, focada na performance sustentável e ancorada em stakeholders prioritários, que automaticamente incitou o relacionamento com colaboradores, clientes, acionistas e sociedade.

Para a LATAM, as equipes de comunicação tanto no Brasil (TAM) como no Chile (LAN) possuem acesso rápido e fácil à alta gestão, que vem demonstrando comportamento coerente, por meio de mensagens claras e transparentes ao longo do tempo. Entretanto, não foi possível identificar uma atuação mais efetiva da liderança no processo comunicacional, que se revela mais como suporte informativo. Questionada sobre o papel das relações públicas no processo de integração, a entrevistada Adriana Vera e Silva afirmou:

A definição deste papel, embora seja batida, é real, é estratégica. Porque a transmissão de mensagens do porquê da fusão, por exemplo, é feita muito via imprensa, nas relações com governo, etc. Você tem um mote muito importante de transmissão que é a equipe de PR que faz. Foi feito um posicionamento cuidadoso de respeitabilidade dos executivos LATAM em relação às autoridades brasileiras. Você não tem uma entrada de executivos chilenos. Isso foi feito com a equipe de comunicação. Isso já existia de modo real na operação, mas o fato de tomar cuidado para que as pessoas do país falem naquele país, isso é um ponto de gentileza que a equipe de comunicação fez muito. $O$ fato de mostrar com muita transparência os resultados. O grupo LATAM se mantém como companhia aberta. Mostrar as dificuldades no processo de fusão. De quando ela era para acontecer até 2012 , você teve uma queda das economias latino americanas e no Brasil, muito importantes. Tudo isso tem sido mostrado de uma maneira muito transparente. Acho que isso contribui muito para ganhar confiança dos mercados. Tem um principio de transparência. Por exemplo, teremos uma nova marca? Sim, teremos. Então se fala. E ao mesmo tempo, desde a fusão se anunciou o seguinte 'vamos nos manter, em princípio, como duas empresas diferentes e vamos estudar a questão de uma marca única'. Isso sempre foi dito. Não teve uma mudança de discurso. Isso contribui para estabelecer uma relação de confiança na companhia. E no nosso trabalho existe uma proximidade muito grande com a alta gestão. Nós somos ouvidos aqui. Nós temos um papel estratégico aqui e da mesma forma lá. $E$ as duas equipes, juntas, conseguem ter acesso rápido à gestão. 


\subsubsection{Comunicação e relacionamento com públicos internos}

\section{Caso 1: BRF}

No período em que o processo de integração da BRF se manteve estagnado, como a espera de dois anos pela aprovação dos órgãos reguladores, seguido por quase três anos de conflitos internos, não houve trabalho estratégico de comunicação para fusão, que trabalhou apenas no papel informativo. Na medida em que o processo adquiriu cadência acelerada, após drásticas mudanças nas diretrizes do negócio, a comunicação assumiu caráter estratégico: no final de 2013, foi criada a Diretoria de Comunicação Global, que desenvolveu o plano para construção da nova cultura organizacional. A partir do mapeamento dos atributos desejados e rejeitados e validação nos mais diversos níveis hierárquicos, foi elaborado o Viva BRF, conjunto de sete valores que norteiam suas ações e relações: amor de dono, inconformismo positivo, fome de performance, é pra já, fazendo juntos, inspirados pelo consumidor e vida saudável. (BRF, 2015) A divulgação vem sendo cascateada em múltiplos canais e formatos de comunicação, com o objetivo de se tornar parte efetiva da realidade do público interno da organização. À medida que novas ações são realizadas, um aparato de mensuração entra em vigor, como enquetes eletrônicas, pesquisas de adesão de valores, pesquisas de clima e grupos focos, que apontam a evolução do processo e pontos de melhorias.

Em meio aos desafios a serem superados pela comunicação interna, estava a questão de a fusão ter surgido após tentativa fracassada de aquisição hostil, portanto os conflitos e o clima de rivalidade vinham da alta liderança. Por conta disso, diversas equipes permaneceram não integradas e atuando de forma separada até 2013. Outro aspecto não relacionado propriamente à fusão, mas com a configuração do negócio, era o fato de oitenta por cento dos funcionários não possuírem acesso à Internet ou computadores, o que representa enorme desafio de capilaridade dos valores para uma realidade de cerca de cem mil funcionários.

\section{Caso 2: Itaú Unibanco}


Ao passo que o processo de integração do Itaú Unibanco aconteceu de forma ágil e deliberativa, com o processo de governança definido no primeiro mês após o anúncio e aprovação do Banco Central em apenas três meses, a comunicação interna caminhou acelerada, visando, nos primeiros seis meses, informar e criar um ambiente de aceitação para as mudanças que viriam, com o aval de um comitê gestor da alta liderança criado especialmente para este fim. Para estabelecer o plano de comunicação com os funcionários, foi criado um comitê de comunicação interna com integrantes dos dois bancos, que conduziam ações e canais específicos sobre a união, com objetivos que se transformaram ao longo das etapas do processo: inicialmente buscou-se a integração, por meio do conhecimento e entendimento do que seria a nova organização e de que forma ela se desenhava. $A$ partir das informações transmitidas, foram abertos canais de diálogo, não somente da área de comunicação com os funcionários, mas como indutora de conversas internas das lideranças com suas equipes. Ao mesmo tempo em que a comunicação buscava dar sentido e senso de pertencimento a este novo contexto, era preciso lidar com aspectos práticos, como realidades tecnológicas diferentes e orientações administrativas para a movimentação física de cerca de 600 pessoas por semana, ao longo de vários meses. (ADEM, 2012, p. 106) Para a entrevistada Valerie Adem, o trabalho da comunicação interna pode ser dividido em duas etapas:

No começo a comunicação era muito mais informativa. Depois, a partir do momento que a gente foi construindo uma nova cultura, foi se definindo qual seria a marca de fato, qual seria a cultura do banco, qual seria o posicionamento do banco, até externo, é que passou-se para um momento de engajamento. Então acho que os primeiros seis meses, talvez, a gente tinha mais uma fase de comunicação informativa e aí a gente entrou na fase do engajamento.

Com a definição dos novos caminhos e estruturas da empresa, o foco da comunicação interna passou a ser o desenvolvimento e internalização da nova cultura corporativa, o "Nosso Jeito de Fazer", criado com base no "Jeito Unibanco" e "Modo Itaú de Fazer", as culturas oriundas. A escolha das dez atitudes norteadoras da nova organização mostrou alinhamento ao seu primeiro slogan: "Um mais um maior que dois", ao incentivar a busca das melhores práticas de cada lado. Entretanto, em meio a valores incontestes como a paixão pela performance herdada do Itaú ou a busca pela agilidade e descomplicação habitual do Unibanco, também surgiram os reforços inversos, ou seja, atitudes históricas de um ou outro lado que 
deveriam mudar, como "Carteirada não vale", "Inovação com foco" e "Processos servindo pessoas". Na sequência, O presidente executivo e o presidente do Conselho de Administração, respectivamente os antigos CEOS de Itaú e Unibanco, fizeram um evento com os quase 15 mil gestores da companhia, para fortalecer as diretrizes de futuro. Um forte indicador de sucesso na disseminação dos novos valores foi um reconhecimento inédito conquistado logo após a fusão. O novo banco foi eleito, por seus funcionários, entre as "Melhores Empresas para se Trabalhar" da Revista Exame, feito até então não alcançado por nenhuma das duas empresas oriundas.

Dentre os inúmeros desafios de uma associação desse porte, o processo apresentou singularidades, como a necessidade imediata da nova corporação desconstruir o mito de aquisição que surgiu dentro e fora de seus muros, devido ao histórico constante de rumores sobre a aquisição do Unibanco por outras instituições financeiras, além do fato dos controladores do Unibanco possuírem metade das ações dos controladores do Itaú na nova holding. Além disso, a escolha da marca ter recaído para um dos lados gerou dúvidas sobre a veracidade da fusão, ainda que o nome Unibanco tenha permanecido na razão social e em alguns elementos simbólicos, como os e-mails de seus cem mil funcionários. Apesar do mote de sua campanha publicitária logo apos a fusão: "Meu nome é Itaú Unibanco, mas pode me chamar de Itaú" dar margem para questionamentos externos, segundo a empresa, a escolha se deu de forma tranquila pela alta liderança, por razões econômicas, pois a marca Itaú era a mais valiosa do país e possuía alguns diferenciais, como a exclusividade na utilização da cor laranja para o mercado financeiro. Neste aspecto, o que contribuiu para o trabalho da comunicação institucional e interna foi a permanência do CEO do Unibanco, Pedro Moreira Salles, como Presidente do Conselho de Administração da nova organização, bem como o modelo adotado de governança compartilhada igualmente, apesar da diferença nos valores de mercado dos bancos (HESSEL e SALOMÃO, 2008).

\section{Caso 3: LATAM}

Dos três casos estudados, o processo de integração de operações da LATAM encontra-se no ritmo mais lento, o que impacta diretamente a velocidade do 
processo comunicacional. Foram despendidos dois anos de trabalho meramente informativo na expectativa das aprovações legais de todos os países envolvidos, seguidos pelo mesmo período para desenho da nova cultura, lançada em meados de 2014, com o conceito "Paixão é o que nos faz voar". Os quatro pilares, Segurança, Cliente, Equipe e Excelência, tem sido disseminados para todos os níveis hierárquicos da empresa, por meio de conceitos macro e reforçados por meio de metas. Gradualmente estes temas são abordados para públicos externos, dentro do contexto de relacionamento já existente.

Ainda que o plano de comunicação tenha sido compartilhado entre LAN e TAM, a fala da executiva entrevistada reforça a percepção de existência de duas empresas coligadas, conduzidas por duas estruturas parceiras. Um dos fatores para esta visão dicotômica se dá na manutenção das duas marcas, que, de acordo com a organização, serão unificadas em uma identidade visual única ainda em 2015. Junte-se a isso o fato dos sistemas e operações não estarem integrados, em função da complexidade do negócio aéreo, e que, à exceção da alta gestão, as estruturas permanecerão atuando em paralelo para atender aos países distintos, é natural que LAN e TAM sejam percebidas como empresas apartadas, ainda que contraproducente para quem pretenda consolidar uma nova cultura organizacional.

A convivência entre equipes de línguas e atitudes não familiares fez com que o processo adquirisse desafios específicos para a comunicação. Não se tratava somente de substituir as culturas organizacionais de duas empresas que não existiam mais por uma nova, com o melhor dos dois lados empresariais. Esta nova cultura devia considerar também aspectos regionais de ambos os países, ampliando, com isso, espaço para uma resistência ainda maior. Outro fator complicador decorrente da união multinacional foi a dificuldade de comunicação entre os lados, tanto pela diferença nos idiomas como pela falta de estrutura, que ia da falta de salas de videoconferência à baixa qualidade da comunicação telefônica.

Para criar parâmetros de mensuração que no futuro possam contribuir para o trabalho da comunicação interna e na avaliação da cultura recém implantada, em 2014 a empresa iniciou uma metodologia de pesquisa interna baseada no índice de saúde organizacional. 


\subsubsection{Comunicação e relacionamento com públicos externos}

\section{Caso 1: BRF}

Com relação ao relacionamento com os públicos externos, a BRF partiu da premissa que a construção cultural deveria acontecer de dentro para fora. A partir do momento em que os atributos foram estabelecidos e trabalhados internamente, passaram a ser adaptados aos públicos externos, à luz das necessidades específicas de cada interlocutor. A prioridade foi de manter a coerência e unicidade das mensagens, mas com linguagens adaptadas a cada público. Na percepção de Marcos Caetano, como as empresas oriundas se pareciam, elas tentavam montar estruturas similares, com isso, tinham características externas que, segundo ele, não se diferenciavam para os stakeholders. Portanto, na percepção da empresa, o relacionamento destes públicos não foi fortemente impactado, apenas o porte desta interlocução, e nenhum dos novos valores impacta negativamente seus públicos.

Apesar de o site BRF ser bastante completo, com possibilidade de customização de acesso conforme perfil de público, e possuir espaço para todas as suas marcas, os sites Sadia e Perdigão continuam ativos, com formatos e identidades visuais distintas. Apesar de focarem prioritariamente suas linhas de produtos, ambos mantêm abas institucionais, onde suas histórias são apresentadas separadamente, com breve menção à fusão e criação da BRF. Nas redes sociais, a empresa mantém as páginas Sadia (3,4 milhões de seguidores) e Perdigão (659 mil seguidores) e não possui uma pagina institucional. Atualmente, a área responsável pela comunicação é a Diretoria de Comunicação Global, dividida em quatro pilares: marca corporativa; eventos e comunicação com stakeholders; comunicação interna e endomarketing e PR: imprensa, entidades de classe, formadores de opinião.

\section{Caso 2: Itaú Unibanco}

No primeiro momento após o anúncio da fusão, a comunicação com os públicos externos do Itaú Unibanco foi meramente informativa, visando controlar sua ansiedade por informações ainda não disponíveis, como definição de estruturas e de marcas. E valeu-se da repercussão positiva que causou frente ao caótico cenário 
político-econômico mundial que marcou o ano de 2008. Naquele momento, não eram muitas as organizações no chamado primeiro mundo que poderiam utilizar o discurso de solidez e liderança, o que contribuiu para seu objetivo de posicionar-se como uma empresa com aspiração de ser global. Questionado sobre a forma de (re)engajamento dos stakeholders , o entrevistado Paulo Marinho afirmou:

Aqui não era para inventar a roda. Tem um tema que foi emblemático
e foi diferenciador, que foi o processo de governança criado na
companhia, não só para a comunicação. Não dá para entender o
processo de governança da comunicação distante do processo de
governança da fusão, da companhia. Foi instalado um processo de
governança com 19 comitês temáticos para tratar da fusão. A
comunicação era um deles. O fato da comunicação estar dentro
desta governança maior já foi um salto enorme. Na prática, essa
governança, com grupos de trabalhos, com comitês específicos para
tratar esse assunto, comitês bipartites e tripartites, com áreas de
comunicação, recursos humanos, marketing, área de corporate
affairs, sentadas nesta mesma área, fez com que a gente tivesse
uma agilidade muito grande no processo. Então havia uma
comunicação bastante intensa [...] Acho que houve um outro
processo também importante, que é o de escuta, o de auscultar.
Tomava-se o pulso, com muita constância, do clima. Então a gente
conseguia saber o que está sendo assertivo ou não. Os indicadores
foram bastante positivos.

Com a fusão, na concepção da organização, sua desejada posição de liderança impôs um senso de responsabilidade maior, que exigia sair da zona de conforto no habitual relacionamento com os stakeholders. A relação mudou radicalmente e para melhor, a partir da criação de uma estratégia de performance sustentável, na qual a empresa assumiu um compromisso de longo prazo para seus negócios, por meio da geração de valor para funcionários, clientes, acionistas e sociedade. Com isso, tornou-se imprescindível o trabalho estruturado e planejado de relacionamento com os públicos. A estrutura de comunicação institucional, até então dirigida para ações de relacionamento com a imprensa, se viu alavancada para um novo patamar, o de engajamento de seus públicos prioritários, por meio do diálogo efetivo, com foco na ausculta de seus interesses e necessidades, que passaram a ser levados de fora do banco para dentro de forma sistemática. Para Paulo Marinho, superintendente de Comunicação Corporativa do Itaú Unibanco, este cenário suprimiu um dilema recorrente nas áreas de relações públicas das empresas contemporâneas sobre seu papel na estratégia de negócios: 
O fato de a gente ter, na fusão, desenhado a estratégia do negócio baseada em stakeholders prioritários, deu para a área de comunicação corporativa, um guia, uma âncora, um alicerce muito forte para fazer o planejamento de engajamento de stakeholders. Ai quando falo em engajamento, estou falando no processo de comunicação, de conversas e tudo mais. Então automaticamente o que aconteceu aqui foi que a área de comunicação corporativa ficou muito mais forte. Aconteceu um fenômeno aqui extremamente interessante, porque um grande dilema que se trata hoje é 'e a comunicação corporativa, qual a importância que ela tem? Ela está na estratégia?' No nosso caso, ela já entrou por causa da estratégia!"

A estrutura atual de comunicação divide-se entre: Superintendência de Endomarketing, com reporte à Diretoria de Marketing Institucional, criada a partir das áreas de comunicação interna de $\mathrm{RH}$ e institucional do Itaú e endomarketing do Unibanco, e a Superintendência de Comunicação Corporativa, com reporte à Diretoria Executiva de Marketing, composta por três gerências: reputação, comunicação corporativa do Itaú Unibanco e comunicação corporativa do Itaú BBA, braço de negócios com pessoas jurídicas de grande porte.

Do ponto de vista comunicacional, os velhos Itaú e Unibanco fazem parte do passado que a organização preserva como memória, mas deixa claro que não existem mais. Ainda que os elementos visuais remetam mais fortemente pelos atributos do antigo Itaú pela escolha da marca comercial, alguns elementos Unibanco foram incorporados no dia a dia da nova organização, como os ícones "30 horas" e "Uniclass". Os antigos sites Itaú e Unibanco deixaram de existir, dando lugar para um site único que conta as histórias em uma linha do tempo dupla até 2008. Nas redes sociais, a empresa possui perfil único com cerca de 7 milhões de fãs.

\section{Caso 3: LATAM}

O plano de comunicação da LATAM com seus públicos externos para a fusão foi desenvolvido a quatro mãos pelas equipes LAN e TAM, com a liderança do vicepresidente de marketing da LAN, inicialmente para apresentar a nova organização. Além disso, foi criada uma frente de trabalho de marketing, responsável pela comunicação com cliente, em suas várias instâncias, desde SAC, publicidade, fidelidade, entre outros. Recentemente, ao lançar a nova cultura, houve um 
desdobramento para reforçar os novos atributos para os públicos considerados prioritários: imprensa, governo e clientes. O principal desafio é fazer com que a nova companhia aérea que aspira um posicionamento mundial, consiga pensar de maneira mais abrangente, atendendo ao ritmo intenso de velocidade da comunicação externa, principalmente das redes sociais, que gera necessidade de ter uma comunicação global forte e ágil.

Uma demonstração clara do descompasso institucional para os públicos externos é a manutenção dos sites LAN e TAM não somente para cumprir sua função de comercializar passagens, mas com identidades visuais e estruturas institucionais em separado: história, atendimento à imprensa, projetos sociais, sustentabilidade, entre outros. Nos dois sites, as histórias são contadas de maneiras divergentes: o site TAM aborda apenas o histórico desta empresa, enquanto o site LAN conta ambas as histórias até 2010, momento da fusão. De lá para os tempos atuais, apenas a história LAN é relatada. O único elo LATAM nos dois sites são os ícones "Relações com Investidores", que remetem ao site LATAM, totalmente direcionado para prestação de contas aos acionistas. Nas redes sociais, as páginas da LAN e TAM possuem 4,8 e 2,8 milhões de fãs, respectivamente, no Facebook. A LATAM não possui página no Facebook.

As áreas de comunicação de LAN e TAM possuem modelos de suas estruturas diferentes entre si e a equipe do Brasil se reporta à do Chile. Na LAN, há uma vice presidência de assuntos corporativos, com equipe no Chile e uma equipe em cada um dos países da América Latina, enquanto que a TAM possui uma diretoria de relações institucionais e sustentabilidade, com 4 gerências: imprensa, relações institucionais e governamentais, comunicação interna e sustentabilidade.

Este cenário reflete não somente o momento da atual da companhia, que ainda está no meio de seu processo de integração operacional e em vias de criar sua marca única, mas também as particularidades de uma combinação entre empresas de diferentes países, que enfrentam desafios específicos decorrentes da distância, das legislações e das culturas nacionais. 


\subsubsection{Análise dos dados versus questões de combate à Merger Syndrome}

Com base nos resultados apresentados, a figura 16 apresenta o nível de aderência das organizações estudadas em relação às questões apontadas por Marks e Mirvis (2010, p. 40) como fundamentais para o combate da Merger Syndrome apresentada no capitulo dois.

\begin{tabular}{|c|c|c|c|c|c|c|c|}
\hline & \multirow{2}{*}{$\begin{array}{l}\text { Base para } \\
\text { análise }\end{array}$} & \multicolumn{2}{|c|}{ BRF } & \multicolumn{2}{|c|}{$\begin{array}{c}\text { Itaú } \\
\text { Unibanco }\end{array}$} & \multicolumn{2}{|c|}{ LATAM } \\
\hline & & Fusão & Atual & Fusão & Atual & Fusão & Atual \\
\hline $\begin{array}{l}\text { Estratégia } \\
\text { voltada à } \\
\text { criação de valor }\end{array}$ & $\begin{array}{c}\text { Dados dos quadros } \\
10,11 \text { e } 12\end{array}$ & Pouca & Muita & Muita & Muita & Média & Média \\
\hline Organização & $\begin{array}{l}\text { 4.4. Resultados da } \\
\text { Pesquisa }\end{array}$ & Pouca & Muita & Muita & Muita & Média & Muita \\
\hline $\begin{array}{l}\text { Atenção às } \\
\text { pessoas }\end{array}$ & $\begin{array}{l}\text { 4.4.3. Comunicação } \\
\text { e Relacionamento } \\
\text { com Stakeholders }\end{array}$ & Pouca & Muita & Muita & Muita & Média & Muita \\
\hline $\begin{array}{l}\text { Nova cultura } \\
\text { desejada }\end{array}$ & $\begin{array}{c}4.4 .3 .1 . \\
\text { Comunicação e } \\
\text { relacionamento com } \\
\text { públicos internos }\end{array}$ & Pouca & Muita & Muita & Muita & Pouca & Média \\
\hline $\begin{array}{l}\text { Estrutura de } \\
\text { transição }\end{array}$ & $\begin{array}{l}\text { 4.4. Resultados da } \\
\text { Pesquisa }\end{array}$ & Pouca & Muita & Muita & Muita & Média & Média \\
\hline
\end{tabular}

Quadro 16 - nível de aderência das organizações às questões de combate à Merger Syndrome.

Elaborado pela autora. 


\subsubsection{Análise dos dados versus Teoria da Excelência em Relações Públicas}

A figura 17 apresenta o nível de aderência das organizações estudadas em relação às categorias e princípios da Teoria da Excelência em Relações Públicas, de James Grunig (2011, p. 53), apresentados no capitulo quatro, em dois momentos: na época da fusão e atualmente.

\begin{tabular}{|c|c|c|c|c|c|c|c|}
\hline \multirow{2}{*}{$\begin{array}{l}\text { Categorias das RP } \\
\text { Excelentes }\end{array}$} & \multirow{2}{*}{$\begin{array}{l}\text { Base para } \\
\text { análise }\end{array}$} & \multicolumn{2}{|c|}{ BRF } & \multicolumn{2}{|c|}{$\begin{array}{c}\text { Itaú } \\
\text { Unibanco }\end{array}$} & \multicolumn{2}{|c|}{ LATAM } \\
\hline & & Fusão & Atual & Fusão & Atual & Fusão & Atual \\
\hline $\begin{array}{l}\text { Empoderamento } \\
\text { das Relações } \\
\text { Públicas }\end{array}$ & $\begin{array}{l}\text { 4.4. Resultados } \\
\text { da Pesquisa }\end{array}$ & Pouca & Muita & Média & Muita & Média & Muita \\
\hline $\begin{array}{l}\text { Papéis em Relações } \\
\text { Públicas }\end{array}$ & $\begin{array}{l}\text { 4.4. Resultados } \\
\text { da Pesquisa }\end{array}$ & Pouca & Muita & Muita & Muita & Média & Muita \\
\hline $\begin{array}{l}\text { Organização da } \\
\text { comunicação, } \\
\text { relacionamento com } \\
\text { outras funções e } \\
\text { consultorias }\end{array}$ & $\begin{array}{l}\text { 4.4. Resultados } \\
\text { da Pesquisa }\end{array}$ & Média & Muita & Muita & Muita & Muita & Muita \\
\hline $\begin{array}{l}\text { Modelos de } \\
\text { Relações Públicas }\end{array}$ & $\begin{array}{l}\text { 4.4. Resultados } \\
\text { da Pesquisa }\end{array}$ & Média & Muita & Média & Muita & Média & Média \\
\hline $\begin{array}{l}\text { Características de } \\
\text { programas } \\
\text { individuais de } \\
\text { comunicação }\end{array}$ & $\begin{array}{c}4.4 .3 . \\
\text { Comunicação e } \\
\text { Relacionamento } \\
\text { com } \\
\text { Stakeholders } \\
\end{array}$ & Pouca & Média & Média & Muita & Pouca & Média \\
\hline $\begin{array}{l}\text { Ativismo e o } \\
\text { contexto ambiental } \\
\text { para a excelência } \\
\text { (externo) }\end{array}$ & $\begin{array}{c}4.4 .3 .2 . \\
\text { Comunicação e } \\
\text { relacionamento } \\
\text { com públicos } \\
\text { externos }\end{array}$ & Pouca & Média & Média & Muita & Pouca & Média \\
\hline $\begin{array}{l}\text { Contexto } \\
\text { organizacional de } \\
\text { relações públicas } \\
\text { excelentes (Interno) }\end{array}$ & $\begin{array}{l}4.4 .3 .1 . \\
\text { Comunicação e } \\
\text { relacionamento } \\
\text { com públicos } \\
\text { internos }\end{array}$ & Pouca & Muita & Muita & Muita & Pouca & Média \\
\hline
\end{tabular}

Quadro 17 - nível de aderência das organizações às categorias e princípios da Teoria da Excelência em Relações Públicas. Elaborado pela autora. 


\subsubsection{Comparativo de premiações de destaque reputacional pré e pós-fusões}

Com base nos rankings de destaque reputacional selecionados para o protocolo de seleção da pesquisa (Empresas mais admiradas do Brasil, da revista Carta Capital; Dow Jones Sustainability Índex; Melhores empresas para se trabalhar, das revistas Exame e Você SA; Guia Exame de Sustentabilidade, da Editora Abril; Prêmio ABERJE e Índice de Sustentabilidade Empresarial (ISE) da BMF\&Bovespa), o quadro 18 compara os reconhecimentos recebidos pelas três organizações, bem como pelas empresas que deram origem a elas.

\begin{tabular}{|c|c|c|c|c|c|c|c|c|c|}
\hline & \multicolumn{3}{|c|}{ BRF } & \multicolumn{3}{|c|}{ Itaú Unibanco } & \multicolumn{3}{|c|}{ LATAM } \\
\hline & Perdigão & Sadia & BRF & Itaú & Unibanco & $\begin{array}{c}\text { Itaú } \\
\text { Unibanco }\end{array}$ & TAM & LAN & LATAM \\
\hline $\begin{array}{l}\text { Empresas mais } \\
\text { admiradas do } \\
\text { Brasil - Carta } \\
\text { Capital }\end{array}$ & - & - & - & $\begin{array}{l}2006 \\
2007\end{array}$ & - & $\begin{array}{l}2010 \\
2011 \\
2012 \\
2013\end{array}$ & $\begin{array}{l}2000 \\
2002 \\
2004 \\
2006\end{array}$ & NA & $\begin{array}{l}2010 \\
2011 \\
2012 \\
2013\end{array}$ \\
\hline $\begin{array}{l}\text { Dow Jones } \\
\text { Sustainability } \\
\text { Index }\end{array}$ & - & - & $\begin{array}{l}2012 \\
2013 \\
2014\end{array}$ & $\begin{array}{l}1999 \\
2000 \\
2001 \\
2002 \\
2003 \\
2004 \\
2005 \\
2006 \\
2007\end{array}$ & - & $\begin{array}{l}2008 \\
2009 \\
2010 \\
2011 \\
2012 \\
2013\end{array}$ & - & - & 2014 \\
\hline $\begin{array}{l}\text { Melhores } \\
\text { empresas para } \\
\text { se trabalhar - } \\
\text { Exame e Você } \\
\text { SA }\end{array}$ & - & - & - & 2008 & 2008 & $\begin{array}{l}2009 \\
2011 \\
2012 \\
2013\end{array}$ & - & - & - \\
\hline $\begin{array}{l}\text { Guia Exame de } \\
\text { Sustentabilidade }\end{array}$ & - & - & $\begin{array}{l}2009 \\
2014\end{array}$ & 2008 & - & $\begin{array}{l}2009 \\
2010 \\
2011 \\
2012 \\
2013 \\
2014\end{array}$ & - & - & - \\
\hline Prêmio ABERJE & - & - & $\begin{array}{l}2010 \\
2012\end{array}$ & $\begin{array}{l}2007 \\
2008\end{array}$ & $\begin{array}{l}2005 \\
2007\end{array}$ & $\begin{array}{l}2010 \\
2011 \\
2012 \\
2013\end{array}$ & 2008 & - & - \\
\hline
\end{tabular}

Quadro 18 - Comparativo de premiações de destaque reputacional pré e pós-fusões. Elaborado pela autora. 
No caso da BRF, observa-se que a empresa já sendo percebida e reconhecida pelo mercado, visto que Sadia e Perdigão não constavam em nenhuma destas premiações. Itaú Unibanco aparece com amplo destaque e reconhecimento reputacional, reforçando ainda mais o posicionamento que já vinha estruturado do Itaú. LATAM demonstra ainda não ser percebida com um capital reputacional maior do que suas antecessoras, uma vez que praticamente apenas manteve a continuidade de um reconhecimento corrente da TAM. 


\section{CONCLUSÕES: REFLEXÕES E TENDÊNCIAS}

O estudo de três organizações de renomado destaque reputacional, oriundas de combinações empresariais, aponta uma série de questões relevantes para o entendimento do papel das relações públicas nos processos de fusões. Não há dúvidas de que o processo combinatório é muito mais profundo do que a integração de sistemas, estruturas ou operações, e exige da organização um minucioso e exclusivo trabalho de reconstrução, seja de sua identidade ou de seus laços relacionais.

Ao analisar as histórias das empresas que deram origem às novas companhias, nota-se que cada uma delas traz em sua essência pressupostos marcantes em relação aos fundadores, que tendem a ser reforçados ou anulados conforme seus novos interesses. A partir das comparações, torna-se evidente que as empresas oriundas podem ter possuído elementos similares em suas histórias e estilos de lideranças, mas, via de regra, elas mais diferiam entre si do que se assemelhavam. Aqui retoma-se a proposição de comunicação intercultural de Fernandez Collado (2008), de buscar mais semelhanças do que desigualdades, com o devido destaque para o fato de que o autor discorre sobre percepção e não sobre constituição. As diferenças mapeadas foram tratadas como complementares pelos gestores de comunicação, que afirmaram ter buscado construir novos modelos, a partir da soma do melhor dos dois lados.

Há de se ressaltar, porém, que a análise dos princípios organizacionais e dos novos valores apontam a predominância de um dos lados, como no caso da Perdigão para a BRF, ou de novos atributos que não pertenciam a nenhum dos lados, demonstrando o surgimento de uma organização com novos propósitos, como a LATAM. Somente o Itaú Unibanco demonstra a presença das antigas origens dos dois lados, em seus valores, ainda que haja um peso levemente maior para o Itaú do que para o Unibanco. Esta desarmonia entre o discurso de fusão de iguais ou soma de partes para construção de algo melhor entra em conflito com a prática de predomínio talvez do mais forte ou apagamento do passado para criação de uma nova história, criando uma dissonância de percepção, por todos os envolvidos, sejam internos ou externos. 
Atitude que pode ser agravada à medida que as novas corporações perpetuam a existência das companhias fusionadas, seja pela manutenção de suas marcas, de antigos sites, páginas nas redes sociais ou de outros ícones que reforçam a existência de algo que não existe mais. Ainda que a escolha dos nomes da nova companhia e das marcas comerciais que permanecerão possa gerar sentimento de perda por um dos lados ou por ambos, representa o momento simbólico do fim das duas histórias e da morte daquelas organizações, para que passado o período de luto, todos possam lembrar de fatos marcantes e seguir em frente, assim como fazem com seus entes queridos. Quanto mais cedo a organização se perceba nova, outra e verdadeiramente única, mais efetivo se demonstra o trabalho de reconstrução de seus laços relacionais.

De maneira geral, as três organizações deram início ao trabalho de relações públicas pelo viés da comunicação instrumental, para que todos os stakeholders ficassem a par dos acontecimentos relacionados às fusões. Somente à medida que os objetivos comunicacionais se tornaram mais estratégicos, é possível perceber a comunicação em seu sentido mais amplo, de gerar compreensão e diálogo. Como se pode constatar ao longo da fundamentação teórica, as dinâmicas das relações de poder variam conforme a história e o estilo de cada empresa. E são elas ou o atrito causado por sua impermanência que afetam diretamente as questões chamadas emocionais ou pessoais dos processos combinatórios e, consequentemente, seu (in)sucesso. Conforme a comunicação se posicionou como facilitadora destas novas relações, seu valor se mostrou mais efetivo, tanto para os próprios responsáveis pelos processos comunicacionais, como pela alta liderança e pelos públicos envolvidos.

A análise da comunicação e do relacionamento com os públicos internos aponta alinhamento com os ritmos impostos nos processos de unificação das operações. Transcursos operacionais diligentes demandam e refletem comunicação ágil e, como consequência, implantação efetiva de novos valores e cultura organizacional. Entretanto, mais do que a velocidade da integração, a efetividade dos novos padrões culturais e políticos reflete a disposição da alta liderança em se desapegar do passado e 'virar a chave' para os novos desafios e propósitos. Os líderes devem transmitir, por meio de seus atos, palavras e postura, os padrões e diretrizes que 
pretendem incorporar à nova organização. Para isso, a área de comunicação interna torna-se mais bem-sucedida conforme concentra esforços antes como fomentadora de uma relação aberta das lideranças com suas equipes, do que no papel meramente operacional de transmissão de informações, por maior que seja a quantidade e variedade de canais criados para tal situação.

Já a observação da comunicação e do relacionamento com seus públicos externos demonstra que, em um primeiro momento, as empresas se sentiram na obrigação apenas de informar sobre as mudanças, sem muitas preocupações sobre as necessidades e interesses das contrapartes. Porém, pela própria configuração das transações, foi preciso um esforço de envolvimento. Isto porque as três organizações possuíam objetivos distintos, adequados aos seus mercados e tendências específicos, mas houve um fio condutor dos três processos de fusão: o de construir companhias com aspirações globais. Portanto, este fato exigia um novo patamar de relacionamentos, em uma sociedade cada vez mais marcada pelo imediatismo tecnológico, pela exposição permanente mesmo que involuntária e pela cobrança de atitudes éticas e sustentáveis. As comparações dos aspectos comunicacionais internos e externos frente às questões de combate à Merger Syndrome e às categorias e princípios da Teoria da Excelência em Relações Públicas confirmam isto, pois claramente o nível de aderência das empresas a tais parâmetros evoluiu indubitavelmente em todos os quesitos, dos momentos centrais das fusões para a realidade atual.

Todos as perspectivas levantadas até aqui remetem a uma questão que vai além dos fatos em si: a percepção sobre eles. Portanto, não adianta a empresa planejar as mudanças, se isso não se refletir de forma sincera, no entendimento de todas as pessoas envolvidas com a organização e que possuem algo a ganhar ou perder nesta relação. A questão reputacional fica evidente no comparativo das premiações de destaque reputacional das empresas oriundas com suas sucessoras. A organização que já era percebida e reconhecida por diversos atores da sociedade, alcançou um reconhecimento cada vez maior após a fusão. As demais, que ainda não tinham uma assimilação significativa deste conceito por parte dos stakeholders, caminham para um progresso gradativo no reconhecimento, à medida que seu processo de reconstrução cultural e relacional evolui. 
Com base nos conceitos até então discorridos e contrapostos, torna-se claro que as relações públicas possuem habilidades suficientes para atuar como agente de transformação e são fundamentais para a criação de uma nova cultura, que seja alinhada às estratégias do negócio vigente, e para a reconstituição dos relacionamentos com os públicos de interesse, nos ambientes de fusões. Mas, para isso, será necessário que seu alicerce seja construído por bases relacionais transparentes, diversas e equilibradas, criadas por intermédio de comunicação dialógica e estratégica, conforme proposta do quadro 19.

\section{Relações públicas como agente de transformação}

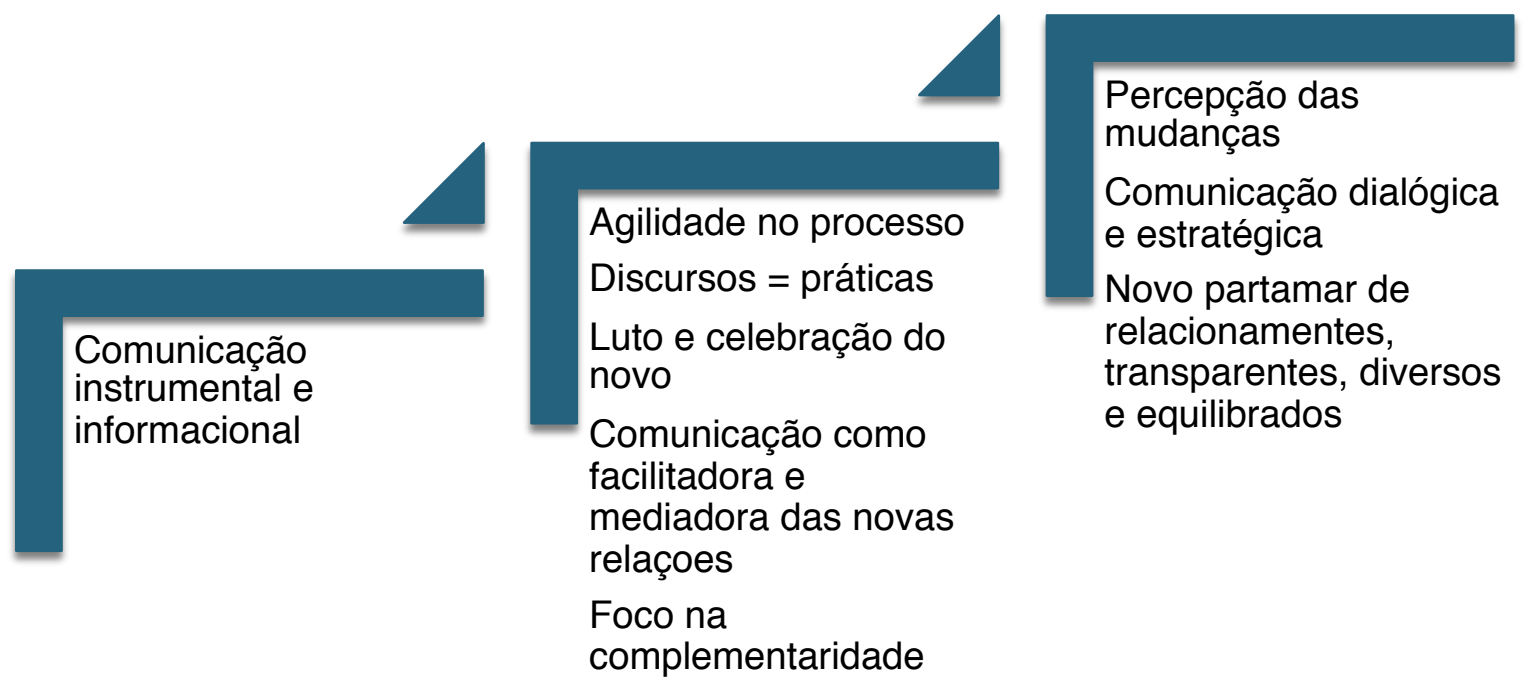

Quadro 19 - Relações públicas como agente de transformação cultural e relacional nos processos de fusões. Quadro elaborado pela autora.

Portanto, ainda que existam pontos de questionamentos e considerações de potenciais aperfeiçoamentos em relação aos três processos comunicacionais estudados, remetendo ao objetivo central deste estudo de estabelecer a correlação do trabalho estratégico de relações públicas em combinações empresariais de grandes organizações e o sucesso dessas fusões, é possível concluir que as relações públicas podem ser intituladas corresponsáveis pelo êxito no alcance ou no encaminhamento para tal dos objetivos estratégicos destes processos combinatórios. Com isso, tornam-se válidos os pressupostos centrais de que o 
entendimento e a aceitação das mudanças pelos públicos são facilitados por um processo comunicacional estratégico, que contribui para a reconstrução dos relacionamentos e beneficia o estabelecimento de novas culturas organizacionais.

Ciente de suas limitações devido à escolha metodológica; por consequência, à quantidade de casos analisados; à exiguidade de tempo; e ao vasto universo de combinações no Brasil e no mundo, este estudo não pretende encerrar a discussão sobre o tema. Ao contrário, ele se propõe a ser mais um ponto de partida para pesquisas futuras, que podem enveredar para novas análises que venham a elucidar quantitativamente as diretrizes aqui apontadas. 


\section{REFERÊNCIAS}

ADEM, V. A comunicação que integra. In: NASSAR, Paulo (Org.). Comunicação interna: a força das empresas. Vol. 6. São Paulo: ABERJE, 2012.

ALMEIDA, A. L. C. A influência da identidade projetada na reputação organizacional. 2005. 361p. Tese (Doutorado em Administração), Centro de PósGraduação e Pesquisas em Administração, Universidade Federal de Minas Gerais, Belo Horizonte, 2005.

ALMEIDA, A. L. C. Identidade, imagem e reputação organizacional: conceitos e dimensões da práxis. In: KUNSCH, Margarida M. Krohling (Org.). Comunicação organizacional: linguagem, gestão e perspectivas. Vol. 2. São Paulo: Saraiva, 2009.

AGÊNCIA NACIONAL DE AVIAÇÃO CIVIL (ANAC). Disponível em: http://www.anac.gov.br. Acesso em: 26 abr. 2015

ANDERSON, H.; HAVILA, V.; NILSSON, F. Mergers and Acquisitions: The Critical Role of Stakeholders. New York: Routledge. 2012

ANDRADE, C. T. S. Curso de Relações Públicas: Relações com os diferentes públicos. $6^{\text {a }}$ ed. São Paulo: Pioneira Thomson, 2003.

ANDRADE, C. T. S. Para entender Relações Públicas. $3^{a}$ ed. São Paulo: Loyola, 2001.

APPELBAUM, S. et al. Anatomy of a merger: Behavior of organizational factors and processes throughout the pre-during - post- stages (part1). Management Decision, Vol. 38. ISS: 9, pag. 649-662, 2000.

BALDISSERA, R. A teoria da complexidade e novas perspectivas para os estudos de comunicação organizacional. In: KUNSCH, M. M. K. (Org.). Comunicação organizacional: Histórico, fundamentos e processos. Vol. 1. São Paulo: Saraiva, 2009.

BALDISSERA, R. Tensões dialógico-recursivas entre a comunicação e a identidade organizacional. Revista Organicom, São Paulo: Universidade de São Paulo, v. 7, p. 228-243, 2007.

BALMER, J. M. T.; DINNIE, K. Corporate identity and corporate communications: the antidote to merger madness. Corporate Communications: An International Journal, West Yorkshire: MCB University Press, Vol. 4, p.182 192, 1999.

BANCO CENTRAL DO BRASIL (BACEN). Disponível em: http://www.bcb.gov.br Acesso em: 26 abr. 2015

BARNETT, M. L.; JERMIER J. M.; LAFFERTY B. A. Corporate Reputation: The Definitional Landscape. Corporate Reputation Review, West Yorkshire: MCB University Press, Vol. 9, n. 1, p. 26-38, 2006. 
BARROS, B. T. Fusões, Aquisições e Parcerias. São Paulo: Ed. Atlas, 2001.

BARROS, B. T. Fusões e aquisições no Brasil: entendendo as razões dos sucessos e fracassos. São Paulo: Atlas, 2003.

BOURDIEU, P. A opinião pública não existe. Les Temp Modemes, n. 318, jan. 1973, p. 1292-1304

BRASIL. Lei $n^{\circ} 6.404$, de 15 de dezembro de 1976. Dispõe sobre as Sociedades por Ações. Diário Oficial da União, Brasília, DF, 15 dez. 1976. Disponível em: http://www.planalto.gov.br/ccivil_03/leis/l6404consol.htm. Acesso em: 15 mar. 2015.

BRASIL. Lei $n^{\circ} 12.529$, de 30 de novembro de 2011. Estrutura o Sistema Brasileiro de Defesa da Concorrência. Diário Oficial da República Federativa do Brasil, Brasília, DF, 30 nov. 2011. Disponível em: http://www.planalto.gov.br/ccivil_03/_ato2011-2014/2011/Lei/L12529.htm. Acesso em: 15 mar. 2015.

BREALEY, R; MYERS, S.; ALLEN F. Princípios de Finanças Corporativas. Porto Alegre: Mc Graw Hill. 10ª ed., 2013.

BRF. Institucional, História, Visão e Missão, Relatórios Anuais. Disponível em: http://www.brf-global.com/brasil. Acesso em 01 fev. 2015.

CASALI, A. Comunicação organizacional em Fusões e Aquisições Internacionais. 2006. Tese (Doutorado em Engenharia de Produção) - Universidade Federal de Santa Catarina, Florianópolis, 2006

CANDAU, J. Memória e identidade. São Paulo: Contexto, 2011.

CARTWRIGHT, S.; COOPER, C. L. Managing Mergers, Acquisitions \& Strategic Alliances: Integrating People and Cultures. Oxford: Butterworth Heinemann, 1999

CHILDS, H. L. Formação da opinião. In: CHILDS, Harwood L. Relações públicas, propaganda e opinião pública. 2. ed. Rio de Janeiro: Fundação Getúlio Vargas, 1967.

DALLA COSTA, A.J.; SOUZA-SANTOS, E.R. Brasil Foods: a fusão entre Perdigão e Sadia. Economia e Tecnologia, v.5, n. 17, p.165-176, 2009.

DUARTE, M. Y. M. Estudo de Caso, In: DUARTE, J; BARROS, A. Métodos e técnicas de pesquisa em comunicação. $2^{a}$ ed. São Paulo: Atlas, 2012.

DUARTE, J.; MONTEIRO, G. Potencializando a comunicação nas organizações. In: KUNSCH, M. M. K. (Org). Comunicação Organizacional: Linguagem, gestão e perspectivas. Vol. 2. São Paulo: Saraiva, 2009.

FARIAS, L. A. O campo acadêmico do ensino e da pesquisa em comunicação organizacional. In: KUNSCH, M. M. K. Comunicação Organizacional: Histórico, fundamentos e processos. Vol. 1. São Paulo: Saraiva, 2009a. 
FARIAS, L. A. Estratégias de relacionamento com a mídia. In: KUNSCH, M. M. K. Gestão Estratégica em Comunicação Organizacional e Relações Públicas. São Paulo: Difusão, 2009b.

FARIAS, L. A. Relações públicas estratégicas. São Paulo: Summus, 2011.

FELIX MATEUS, A. Comunicação Interna e Fusão de Empresas: a necessidade de um Planejamento. Vivat Academia. no 117E. Fevereiro, 2012. Páginas 17661802. Disponível em: http://www.ucm.es/info/vivataca/numeros/n117E/DATOSS.htm. Acesso em 03 Jun. 2015

FERNÁNDEZ COLLADO, C. La comunicación humana en el mundo contemporáneo. $3^{a}$.ed. México: McGraw-Hill, 2008.

FLEURY, M. T.; FISCHER, R. M. Cultura e poder nas organizações. São Paulo: Atlas, 2012.

FOMBRUN, C. J. The two faces of reputation risk: anticipating downsize losses while exploiting upside gains. Revista Organicom. São Paulo: Universidade de São Paulo, ano 4, n. 7, p. 71-83, 2 . Sem. 2007.

FOMBRUN, C. J.; VAN RIEL, C. Why Reputation Matter In: Fame e Fortune: How Successful Companies Build Winning Reputations. Prentice Hall, NY, 2004.

FORTES, W. G. Relações Públicas: Processos, funções, tecnologia e estratégias. $2^{a}$ ed. São Paulo: Summus, 2003.

FRANÇA, F. Públicos: Como Identificá-los em uma Nova Visão Estratégica. $3^{a}$ ed. São Caetano do Sul: Yendis, 2012.

FRANÇA, F. Relações Públicas no século XXI: Relacionamento com Pessoas. In: $\mathrm{KUNSCH}, \mathrm{M}$. M. K. Obtendo resultados com relações públicas. 2a. ed. São Paulo: Pioneira Thomson Learning, 2006.

FREEMAN, R. E. Strategic Management: A Stakeholder Approach. New York: Cambridge University Press, 1984

FREITAS, M. E. Cultura organizacional: evolução e crítica. São Paulo: Thomson Learning, 2007

FREITAS, S. G. Cultura organizacional e comunicação. In: KUNSCH, M. M. K. Obtendo resultados com relações públicas. 2a. ed. São Paulo: Pioneira Thomson Learning, 2006.

FROOMAN, J. Stakeholder influence strategy. Academy of Management Review, Briarcliff Manor, v.24, n.2, p.191-205, 1999.

G1 - Globo.com. Histórias de Itaú e Unibanco são marcadas por aquisições e fusões. Nov. 2008 Disponível em: 
http://g1.globo.com/Noticias/Economia_Negocios/0,,MUL847595-9356,00-

HISTORIAS+DE+ITAU+E+UNIBANCO+SAO+MARCADAS+POR+AQUISICOES+E+ FUSOES.html Acesso em: 02 Nov.2014

GALPIN, T.; HERNDON, M. The Complete Guide to Mergers and Acquisitions: Process Tools to Support M\&A Integration at Every Level. San Francisco: JosseyBass, 2007.

GRUNIG, J.; FERRARI, M. A.; FRANÇA, F. Relações Públicas: teoria, contexto e relacionamentos. $2^{a}$ ed. São Caetano do Sul: Difusão, 2011.

GUARACY, T. O sonho brasileiro: Como Rolim Amaro criou a TAM e sua filosofia de negócios. São Paulo: A Girafa, 2006.

HESSEL, C.; SALOMÃO, A. A primeira múlti das finanças?. Revista Época Negócios. Ed. 22, dez. 2008. Disponível em:

http://epocanegocios.globo.com/Revista/Epocanegocios/0,,EDR85355-9560,00.html . Acesso em 02 Nov. 2014

IASBECK, L. C. A. Imagem e reputação na gestão da identidade organizacional. Revista Organicom. São Paulo: Universidade de São Paulo, ano 4, n. 7, p. 84-97, $2^{\circ}$. Sem. 2007.

IATA - International Air Transport Association. Disponível em: http://www.iata.org. Acesso em: 26 abr. 2015

LANDIM, R. Abílio define meta de 100 dias para BRF. Jornal O Estado de S. Paulo. 23 abr. 2013. Disponível em:

http://economia.estadao.com.br/noticias/geral,abilio-diniz-define-meta-de-100-diaspara-a-brf,151507e. Acesso em 25 Abr. 2015

HOFSTEDE, G. Culturas e organizações: compreender a nossa programação mental. Lisboa: Sílaba, 1997.

HOHLFELDT, A. C.; MARTINO, L. C.; FRANÇA, V. (Org.). Teorias da comunicação: Conceitos, escolas e tendências. Petrópolis: Vozes, 2001.

ITAÚ UNIBANCO. Disponível em: www.itau.com.br. Acesso em: 02 Nov. 2014

KUNSCH, M. M. K. Obtendo resultados com relações públicas. 2a. ed. São Paulo: Pioneira Thomson Learning, 2006.

KUNSCH, M. M. K. Planejamento de relações públicas na comunicação integrada. 5. ed. São Paulo: Summus, 2003.

KUNSCH, M. M. K. Relações públicas e comunicação organizacional: Campos acadêmicos e aplicados de múltiplas perspectivas. São Caetano do Sul: Difusão, 2009. 
LATAM. Histórico, Valores, Relatórios Anuais. Disponível em: http://www.latamairlinesgroup.net. Acesso em: 02 fev. 2015

LIPPMANN, W. Opinião Pública. Petrópolis: Vozes, 2008.

LOPES, V. S. C.; PENAFIERI, V. Opinião e pesquisa: instrumentos de orientação e de avaliação. In: FARIAS, L. A. Relações públicas estratégicas. São Paulo: Summus, 2011

MAQUIAVEL, N. O príncipe. Porto Alegre: L\&PM, 1998.

MARCHIORI, M. As interconexões entre a cultura organizacional e a comunicação. In: KUNSCH, M. M. K. (Org.). Comunicação organizacional: Linguagem, gestão e perspectivas. Vol. 2. São Paulo: Saraiva, 2009.

MARKS, M. L.; MIRVIS, P. H. Joining forces: making one plus onte three in mergers, acquisitions and alliances. San Francisco: Jossey Bass, $2^{\mathrm{a}}$ ed., 2010.

MARQUES, A. C. S. ; MAFRA, R. L. M. Diálogo no contexto organizacional e lugares de estratégia, argumentação e resistência. Revista Organicom, São Paulo: Universidade de São Paulo, v. 10, n. 19, p. 72-84, 2013

MATURANA, H.; VARELA, J. A Árvore do Conhecimento: As bases biológicas da Compreensão Humana. São Paulo: Palas Athena, 2003.

MEYER, C.; COSTA, M. Felizes para sempre? Revista Exame. Edição 944, Mai. 2009 Disponível em: http://exame.abril.com.br/revista-exame/noticias/felizes-sempre473293. Acesso em: 01 Nov. 2014

NAPOLITANO, G.; MANO, C. O Brasil na era dos megabancos. Revista Exame. Edição 931, nov. 2008. Disponível em: http://exame.abril.com.br/revistaexame/noticias/brasil-era-megabancos-401452. Acesso em 01 Nov. 2014

NAPOLITANO, G.; SALGADO, E. O Velocista. Revista Exame. Edição 942, abr. 2009. Disponível em: http://exame.abril.com.br/revista-exame/noticias/velocista466906. Acesso em 01 Nov. 2014

NASSAR, P. Conceitos e processos de comunicação organizacional In: KUNSCH, Margarida M. Krohling (Org). Gestão estratégica em comunicação organizacional e relações públicas. São Caetano do Sul: Difusão, 2009.

NASSAR, P. Relações Públicas na construção da responsabilidade histórica e no resgate da memória institucional das organizações. São Paulo: Difusão, 2007

OLIVEIRA. A. V. M. Estudos dos determinantes de preços das companhias aéreas no mercado doméstico. Rio de Janeiro: Anac, 2009.

OLIVEIRA, I L.; PAULA, M. A. O que é comunicação estratégica nas organizações? São Paulo: Paulus, 2007 
PERDIGÃO. Institucional. Disponível em: http://www.perdigao.com.br. Acesso em 01 fev. 2015.

PÉREZ, R. A. Estratégias de Comunicación. 4ª Ed. Barcelona: Ariel, 2008

PETTIGREW, A. A Cultura das organizações é administrável?. In: FLEURY, M. T.; FISCHER, R. M. Cultura e poder nas organizações. São Paulo: Atlas, 2012.

PUTNAM, L. et al. Communication theory and organizational communication: multiple perspectives. In: JABLIN, F.M et. Al. (orgs). Handbook of organizational communication: In interdisciplinary perspective. Newbury Parky: Sage Publications, 1987.

PUTNAM, L. Organizações e seus aspectos sutis. Revista Organicom. São Paulo: Universidade de São Paulo, ano 5, n. 9, 2008, pag. 219-226.

RABAÇA, C. A.; BARBOSA, G. Dicionário de Comunicação. São Paulo: Campus, 2001.

REIS, M. C. Comunicação e Mudança Organizacional: uma interlocução instrumental e constitutiva. Revista Organicom. São Paulo: Universidade de São Paulo, ano 1, n.1, 2004, p.36-53.

RHINOW, G. O desafio de gestão da mudança em combinações empresariais: a indústria de ciências da vida. 2006. Tese (Doutorado em Administração de Empresas) - Faculdade de Economia, Administração e Contabilidade, Universidade de São Paulo. São Paulo, 2006.

ROSA, M. A reputação sob a lógica do tempo real. Revista Organicom. São Paulo: Universidade de São Paulo, ano 4, n. 7, 2007.

ROSSETTI, J. P. Fusões e Aquisições no Brasil: as razões e os impactos. In: BARROS, B. T. Fusões, Aquisições e Parcerias. São Paulo: Atlas, 2001.

ROUSSEAU, J. J. O contrato social. Porto Alegre: L\&PM, 2011.

SADIA. História, Missão e Visão. Disponível em: http://www.sadia.com.br. Acesso em: 01 fev. 2015.

SCHEIN, E. H. Coming to a New Awareness of Organizational Culture. Sloan Management Review, Cambridge: MIT, v. 25, n. 2, p. 6-13, 1984

SEREIA, V. J.; CAMARA, M. R. G.; VIEIRA, S. F. A. A trajetória competitiva e a internacionalização da empresa Perdigão. Internext - Revista Eletrônica de Negócios Internacionais da ESPM, São Paulo, v. 6, n. 2, p. 138-164, jul./dez. 2011.

SIMÕES, R. P. Relações públicas: função política. São Paulo: Summus, 1995. 
SCHULER, M. A cultura organizacional como manifestação da multidimensionalidade humana. In: KUNSCH, M. M. K. (Org.). Comunicação organizacional: Linguagem, gestão e perspectivas. Vol. 2. São Paulo: Saraiva, 2009.

TAM. História, Missão e Visão. Disponível em: http://www.tam.com.br Acesso em: 02 fev. 2015

TANURE, B.; CANÇADO, V. Fusões e aquisições: aprendendo com a experiência brasileira. Revista de Administração de Empresas. São Paulo: Fundação Getúlio Vargas, v. 45, n.2, p-10-22, abr/jun 2005.

YIN, R. K. Estudo de caso: planejamento e métodos. 4ª ed. Porto Alegre: Bookman, 2010. 


\section{ANEXO A - Comunicado oficial do Conselho Administrativo de Defesa Econômica (CADE) sobre criação da BRF}

\section{Cade aprova, com restrições, a criação da BRFoods}

O Plenário do Conselho Administrativo de Defesa Econômica (Cade) reuniu-se nesta quarta-feira, 13 de julho de 2011, para realização de sua 495 ${ }^{a}$ Sessão Ordinária de Julgamento. $O$ destaque foi $O$ julgamento do Ato de Concentração 08012.004423/2009-18, que cria a BRFoods.

\section{Entenda o processo}

A BRFoods, empresa criada pela fusão da Sadia S.A e a Perdigão S.A., protocolou sua operação no Sistema Brasileiro de Defesa da Concorrência em 09 de junho de 2009.

O Cade assinou com a empresa um Acordo de Preservação da Reversibilidade da Operação - APRO, em 08 de julho de 2009, garantindo que, caso a fusão não fosse aprovada, as empresas teriam condições de desfazer a operacão sem grande impacto para o mercado, consumidores e funcionários.

O processo recebeu parecer da Secretaria de Acompanhamento Economico - SEAE, parecer da Procuradoria do Cade e entrou na Pauta da 492 ${ }^{a}$ Sessão Ordinária de Julgamento, em 08 de junho de 2011.

$\mathrm{Na}$ ocasião, o Conselheiro Relator Carlos Ragazzo, emitiu seu voto contra a fusão das empresas e o Conselheiro Ricardo Ruiz pediu vista do Ato de Concentração.

\section{A decisão}

Desde o dia 8 de junho, o Conselheiro Ruiz participou, juntamente com outros conselheiros, de 12 reuniões com as requerentes e com empresas concorrentes.

Hoje, Ruiz apresentou seu voto, aprovando a operação, com restrições previstas em um Termo de Compromisso de Desempenho - TCD. Vale ressaltar que o Conselheiro considerou o voto do Conselheiro Ragazzo base das negociações que foram feitas entre este Conselho e as empresas.

O voto do Conselheiro Ruiz foi acompanhado pelos conselheiros Olavo Chinaglia, Alessandro Octaviani e Marcos Paulo Verissimo. O Conselheiro Ragazzo manteve seu voto contra a fusão.

Por 4 votos a 1, a fusão foi aprovada pelo Cade, com restrições.

Clique aqui para ler a versão pública do Termo de Compromisso de Desempenho.

O Conselheiro Chinaglia, que presidiu a Sessão em virtude do impedimento do presidente Furlan, considerou este caso "o maior da historia do Cade".

Assessoria de Comunicação do Cade

(61) $3221-8444$

Fonte: Site CADE -

http://www.cade.gov.br/Default.aspx?b78a9860b167bd45d17fd96af9 


\section{ANEXO B - Fato relevante - Associação entre Itaú e Unibanco}

\section{Sumário Executivo}

Os controladores da Itaúsa e da Unibanco Holdings comunicam ao mercado que assinaram nesta data contrato de associação visando à unificação das operações financeiras do Itaú e do Unibanco de modo a formar o maior conglomerado financeiro privado do Hemisfério Sul, cujo valor de mercado fará com que ele fique situado entre os 20 maiores do mundo. Trata-se de uma instituição financeira com a capacidade de competir no cenário internacional com os grandes bancos mundiais.

A associação aqui referida contemplará reorganização societária, que resultará na migração dos atuais acionistas do Unibanco Holdings S.A. ("Unibanco Holdings") e Unibanco - União de Bancos Brasileiros S.A. (“Unibanco"), mediante incorporações de ações, para uma companhia aberta, a ser denominada Itaú Unibanco Holding S.A., atual Banco Itaú Holding Financeira S.A. ("Itaú Unibanco Holding"), cujo controle será compartilhado, entre a Itaúsa - Investimentos Itaú S.A. e os controladores da Unibanco Holdings, por meio de holding não financeira a ser criada no âmbito da reorganização aqui tratada.

As ações ordinárias do Unibanco e da Unibanco Holdings de titularidade dos acionistas não controladores serão substituídas por ações ordinárias do Itaú Unibanco Holding, observando a mesma relação de troca que foi negociada entre as partes para a substituição das ações ordinárias dos controladores da Unibanco Holdings.

Para as ações preferenciais, a relação de troca foi fixada com base na cotação média de mercado, na Bovespa, nos últimos 45 pregões, das Units (certificados de ações que representam, cada um, uma ação preferencial do Unibanco e uma ação preferencial da Unibanco Holdings) e das ações preferenciais do Banco Itaú Holding Financeira S.A.. Tanto as Units quanto as ações preferenciais do Banco Itaú Holding Financeira S.A. integram o IBX-50 e o Ibovespa, além de serem negociadas no pregão da Bolsa de Nova York ("NYSE").

A conclusão da reorganização societária aqui descrita depende da aprovação do Banco Central do Brasil e das demais autoridades competentes.

O que resulta desta associação é um banco brasileiro com o compromisso, a solidez e a capacidade econômica capaz de transformá-lo em um agente vital para o desenvolvimento das empresas nacionais e do país.

\section{DETALHAMENTO DA OPERAÇÃO}

Os controladores da Itaúsa e da Unibanco Holdings comunicam ao mercado que, como fruto de negociações mantidas sob sigilo ao longo dos últimos 15 meses, assinaram hoje contrato de associação visando à unificação das operações financeiras do Itaú e do Unibanco de modo a formar o maior conglomerado financeiro privado do Hemisfério Sul, cujo valor de mercado fará com que fique situado entre os 20 maiores do mundo. Trata-se de uma instituição financeira com a capacidade de competir no cenário internacional com os grandes bancos mundiais.

A associação aqui referida contemplará reorganização societária, que resultará na migração dos atuais acionistas do Unibanco Holdings S.A. ("Unibanco Holdings") e Unibanco - União de Bancos Brasileiros S.A. ("Unibanco"), mediante incorporações de ações no atual Banco Itaú Holding Financeira S.A., que passará a ser denominada Itaú Unibanco Holding S.A. ("Itaú Unibanco Holding"), cujo controle será compartilhado entre a Itaúsa - Investimentos Itaú S.A. e a Família Moreira Salles, 
por meio de holding não financeira a ser criada no âmbito da reorganização aqui tratada.

O ITAÚ e o UNIBANCO entendem que, com essa associação, passarão a oferecer o que há de melhor no mercado brasileiro para seus milhões de clientes corporativos e de pessoas físicas. O Itaú Unibanco Holding reune aspectos marcadamente complementares das duas instituições.

1. OBJETIVO

Com um patrimônio líquido de aproximadamente $R \$ 51,7$ bilhões (30/09/2008) e um lucro líquido de $R \$ 8,1$ bilhões (acumulado até setembro de 2008) fica assegurada uma relevante base de capital para o Itaú Unibanco Holding, preparando-o para:

- reforçar o seu suporte às empresas brasileiras em suas operações nacionais e internacionais;

- expandir a sua atuação no Brasil;

- apoiar o crescimento das operações de crédito de nossos clientes;

- competir no mercado internacional;

- importante ganho de escala em todos os segmentos de clientes; e

- sinergias significativas em vários negócios.

Um dos diferenciais competitivos do ITAÚ e do UNIBANCO é a estratégia de segmentação interna dos negócios, o que permite melhor identificação das necessidades de cada classe de clientes, a criação de produtos e serviços bancários específicos e a otimização do aproveitamento do potencial de cada segmento, fornecendo uma ampla gama de serviços e produtos bancários para uma base diversificada de pessoas físicas e jurídicas. O Itaú Unibanco Holding possibilitará ampliar o potencial dessa cultura de segmentação.

2. ESTRUTURA SOCIETÁRIA

Antes da realização das operações societárias previstas, a Itaúsa transferirá para o Banco Itaú Holding Financeira S.A. a participação societária por ela detida no Banco Itaú Europa S.A., pelo valor aproximado de $\mathrm{R} \$ 1,2$ bilhão, sendo $\mathrm{R} \$ 550$ milhões através da emissão de ações ordinárias do Banco Itaú Holding Financeira (21 milhões de ações) e o restante em dinheiro. Essa transferência não alterará as relações de troca abordadas no item 3.1..

O gráfico abaixo resume a situação atual e a que resultará dessa operação.

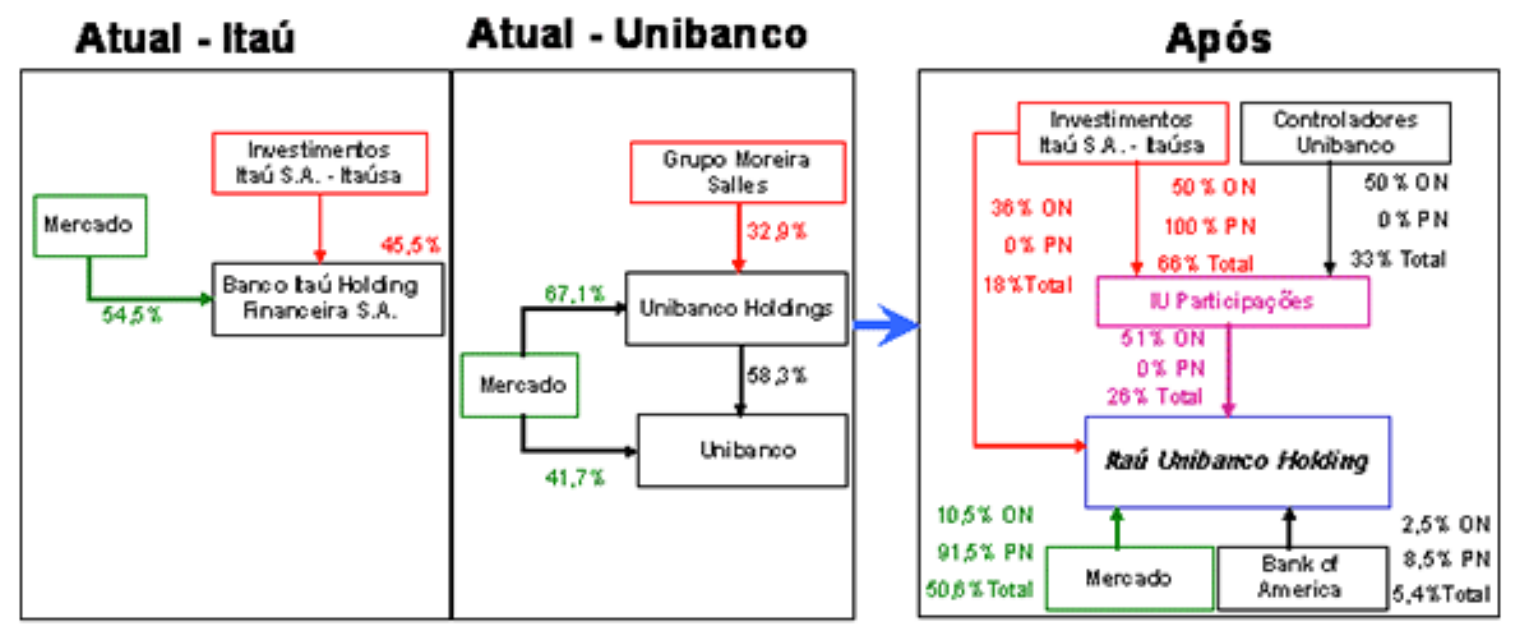

O Itaú Unibanco Holding será controlada pela IU Participações, que deterá as participações acima descritas.

3. RELAÇÕES DE TROCAS DE AÇÕES 


\subsection{Relação de Troca de Ações}

As ações ordinárias do Unibanco e da Unibanco Holdings de titularidade dos acionistas não controladores serão substituídas por ações ordinárias do Itaú Unibanco Holding, observando a mesma relação de troca que foi negociada entre as partes para a substituição das ações ordinárias dos controladores da Unibanco Holdings.

Para as ações preferenciais, a relação de troca foi fixada com base na cotação média de mercado, na Bovespa, nos últimos 45 pregões, das Units (certificados de ações que representam uma ação preferencial do Unibanco e uma ação preferencial da Unibanco Holdings) e das ações preferenciais do Banco Itaú Holding Financeira S.A.. Tanto as Units quanto as ações preferenciais do Banco Itaú Holding Financeira S.A., além de serem negociadas no pregão da Bolsa de Nova lorque, integram o IBX-50 e o Ibovespa.

A quantidade de ações detidas, direta e indiretamente, pela Itaúsa, concluída essa operação, será incrementada em 8,3\%.

A emissão de ações preferenciais e ordinárias totalizará 1.120 .896 mil ações, que equivale a $27,4 \%$ da quantidade total de ações do Itaú Unibanco Holding.

3.2. Negociação

Entre a data da realização da Assembléia Geral Extraordinária, que decidirá sobre a reorganização, e a data de aprovação pelo Banco Central do Brasil, as ações do Itaú e do Unibanco serão negociadas normalmente, tanto na Bovespa - Bolsa de Valores de São Paulo (ações preferenciais e ordinárias), quanto no mercado norteamericano.

3.3. Direitos dos acionistas

No mesmo período citado no item 3.2, o pagamento de dividendos ou juros sobre o capital próprio aos acionistas continuará sendo efetuado pelo Itaú e pelo Unibanco.

4. GOVERNANÇA CORPORATIVA

O Conselho de Administração do Itaú Unibanco Holding será composto por quatorze membros, sendo que seis serão indicados pelos controladores da Itaúsa e pela família Moreira Salles. Os demais oito membros do conselho serão independentes. O Itaú Unibanco Holding terá como Presidente do Conselho de Administração o Sr. Pedro Moreira Salles e como Presidente Executivo o Sr. Roberto Egydio Setubal.

Para propiciar uma transição eficiente e eficaz será criado um Comitê de Transição no Itaú Unibanco Holding que definirá a forma e o ritmo de integração entre as operações do Itaú e o do Unibanco.

As operações e negócios realizados com clientes, credores e fornecedores, não sofrerão nenhuma alteração: o Itaú e o Unibanco continuarão operando no Brasil e no exterior, nos moldes atuais.

\section{PRINCIPAIS DADOS DA OPERAÇÃO}

A associação representa sensível incremento dos dados consolidados, conforme segue: 
$R \$$ Bilhões

\begin{tabular}{|l|c|c|c|}
\hline \multicolumn{1}{|c|}{$\mathbf{3 0}$ de setembro de 2008} & Itaú & Unibanco & Itaú Unibanco Holding \\
\hline Ativos & 396,6 & 178,5 & 575,1 \\
\hline Empréstimos Totais (sem avais e fianças) & 151 & 74,3 & 225,3 \\
\hline Depósitos + Debêntures & 162,7 & 72,4 & 235,1 \\
\hline Patrimônio Liquido (PL) & $32,1(a)$ & 12,9 & 51,7 (b) \\
\hline Lucro Líquido Acumulado (jan.a set.) & 5,9 & 2,2 & 8,1 \\
\hline ROE (sobre PL médio) & $26,3 \%$ & $24,40 \%$ & - \\
\hline Ativos sob administração (AUM) & 209,4 & 55,6 & 265 \\
\hline Valor de Mercado (c) & 69,1 & 18,8 & - \\
\hline
\end{tabular}

(a) Inclui a transferência do Banco Itaú Europa, conforme item 2 acima.

(b) Considerando os efeitos fiscais.

(c) Com base na cotaçăo de fechamento da UBBR11 e ITAU4 de 31 de outubro de 2008.

5.1. Patrimônio Líquido

O patrimônio líquido do Itaú Unibanco Holding será de aproximadamente $R \$ 51,7$ bilhões, transformando-o no conglomerado financeiro de maior base de capital do Brasil (Base: 30/09/2008).

Se a nova estrutura estivesse configurada já neste terceiro trimestre, o Índice da Basiléia seria de $15,1 \%$, considerando-se os efeitos fiscais.

Espera-se que se faça presente contribuição positiva ao lucro líquido consolidado tão logo seja concretizada a operação.

5.2. Instituições reguladoras

A conclusão da associação entre o Itaú e o Unibanco depende da aprovação do Banco Central do Brasil e das demais autoridades competentes.

5.3. Convocação da AGE

As Assembléias que aprovarão as incorporações, necessárias à implementação da associação, serão realizadas entre a última semana de novembro e a primeira de dezembro próximo, conforme a conclusão dos laudos de avaliações contábeis e a mercado que serão preparados por empresas de primeira linha.

6. EFEITOS CONTABÉIS

Considerando-se o aumento de capital relacionado à incorporação de ações, a variação de sua participação acionária e os efeitos contábeis e fiscais, estima-se impactos nos resultados do Itaú Unibanco Holding de $R \$ 7,9$ bilhões e da Itaúsa de $\mathrm{R} \$ 2,5$ bilhões.

7. CONFIANÇA NO FUTURO DO BRASIL

Com essa associação, o Itaú e o Unibanco reafirmam sua confiança no futuro do Brasil, neste momento de importantes desafios no ambiente econômico e no mercado financeiro mundial.

São Paulo, 03 de novembro de 2008 


\section{ANEXO C - Comunicado oficial do Banco Central do Brasil (BACEN) sobre associação entre Itaú e Unibanco}

BC aprova associação entre os conglomerados Itaú e Unibanco 18/02/2009 18:30:00

Brasília - A Diretoria Colegiada do Banco Central do Brasil, em reunião realizada em 18.02.2009, aprovou a associação entre os conglomerados Itaú e Unibanco. A operação compreendeu uma série de atos societários intermediários, culminando com a integração das duas instituições, por meio da constituição da IUPAR - Itaú Unibanco Participações S.A. (holding criada com objeto social exclusivo de participar no capital do Itaú Unibanco Banco Múltiplo S.A.).

O Banco Central concluiu em sua análise que a associação entre os dois conglomerados apresenta características sistemicamente importantes, uma vez que envolve duas instituições de grande porte, com ampla atuação no território nacional e presença em todos os mercados de produtos financeiros no atacado e varejo. Trata-se de iniciativa que contribui para a solidez do Sistema Financeiro Nacional na atual conjuntura do mercado financeiro internacional.

A associação foi analisada sob dois aspectos: societário e de concentração no Sistema Financeiro Nacional. Sob o aspecto societário, o Banco Central concluiu que a iniciativa enquadra-se na estratégia de longo prazo de ambas as instituições, na condição de empresas com vasta experiência no sistema financeiro nacional e de projeção internacional.

Sob a ótica da concentração no SFN, o Banco Central concluiu também que a operação não acarreta prejuízos à concorrência nesse sistema, a despeito de elevar o poder de mercado do novo conglomerado em alguns mercados relevantes de produtos financeiros. Em face dessa nova posição do conglomerado Itaú Unibanco no SFN e dos ganhos de eficiência gerados pela operação, o Banco Central decidiu vincular a sua aprovação à observância de compromissos de desempenho no sentido de compartilhar tais ganhos com a sociedade. Essa decisão está em linha com metodologia utilizada por agências antitruste no País e no exterior.

Tais compromissos, assumidos pelo novo conglomerado como contribuição para reduzir os preços de serviços bancários, estão em sintonia com o esforço desenvolvido pelo Banco Central no sentido de estimular a competitividade do Sistema Financeiro Nacional e, consequentemente, elevar a sua eficiência na prestação de serviços à sociedade.

Esses compromissos contemplam:

1. O novo conglomerado se comprometerá a adotar, em relação aos serviços prioritários (Circular 3.371), a menor tarifa praticada por uma das duas instituições Itaú e Unibanco - vigentes em 2.1.2009. A instituição terá 15 dias para adotar o procedimento que deverá ser mantido por um ano;

2. Cumprido o prazo inicial de um ano, se houver necessidade de majoração nos valores das tarifas nos cinco anos subseqüentes, esse reajuste só poderá ocorrer 
naquelas tarifas que se encontrarem com valor inferior à média das tarifas cobradas pelos cinco maiores bancos, não podendo superar jamais essa média;

3. As pessoas jurídicas do conglomerado também se beneficiarão das menores tarifas praticadas por um dos bancos.

18 de fevereiro de 2009

Banco Central do Brasil

Assessoria de Imprensa

imprensa@bcb.gov.br

(61) 3414-3462

Fonte: Site BACEN

http://www.bcb.gov.br/textonoticia.asp?codigo=2041\&idpai=NOTICIAS 
ANEXO D - Trecho do Relatório de Gestão do Conselho Administrativo de Defesa Econômica CADE 2009/2010, sobre fusão entre Itaú e Unibanco

\section{Itaú/Unibanco}

O CADE aprovou sem restrições a fusão entre os bancos Itaú e Unibanco, considerando haver rivalidade suficiente no setor bancário, o que torna pouco provável o exercício do poder de mercado das empresas com a operação.

Além disso, a participação de mercado das empresas só tornou-se superior a $20 \%$ em sete áreas (cartão de crédito, financiamento de veículos para pessoa física, empréstimo em moeda estrangeira para pessoa jurídica, seguros patrimoniais, seguros de responsabilidade, seguros de cascos e previdência privada).

Nos casos de depósito à vista (conta corrente) e poupança, por exemplo, a participação conjunta dos bancos não chega a $20 \%$ do mercado.

(Ato de Concentração: 08012.0011303/2008-96, Banco Itaú S.A. e Unibanco).

Fonte: Site CADE -

http://www.cade.gov.br/upload/Relatorio-de-gestao-2009-2010.pdf 


\section{ANEXO E - Comunicado oficial do Conselho Administrativo de Defesa Econômica (CADE) sobre criação da LATAM}

\section{Cade autoriza criação da Latam}

O Conselho Administrativo de Defesa Econômica - Cade, aprovou ontem, durante sua $506^{a}$ Sessão Ordinária de Julgamento, a fusão da Tam S.A. com a Lan Airlines S.A., com algumas restrições.

O caso refere-se ao ato de concentração 08012.009497/2010-84, que trata de associação entre a TAM e a LAN, por meio de troca de ações entre as partes, criando assim a Latam.

O conselheiro relator Olavo Chinaglia, que foi acompanhado por todos os outros membros do plenário, trouxe seu voto aprovando a operação, impondo restrições em duas linhas de ação, basicamente:

1. A Latam devera efetuar permuta de slots e infraestrutura aeroportuária no aeroporto de Guarulhos, que permita a nova(s) empresa(s) operar em duas frequências diárias na rota São Paulo - Santiago - São Paulo, por meio de voos diretos.

2. Alem disso, a Latam deverá submeter ao Cade sua escolha pela aliança global que irá participar. Atualmente a Tam faz parte da Star Alliance e a Lan da One World. Com a decisão do relator, a Latam participará somente de um dos programas.

O cumprimento da decisão deverá ser comprovado ao Cade em até 90 dias a partir de sua publicação. Além disso, as obrigações tem vigência de 3 anos, prorrogáveis por igual período.

Assessoria de Comunicação do Cade

(61) 3221-8444 / 9287-8591

Fonte: Site CADE -

http://www.cade.gov.br/Default.aspx?d468b642d349df23f7451f3f0a 